Patricia Peláez Bilbao patricia.pelaez@campusviu.es

Universidad Internacional de Valencia

Arturo Tello Ruiz-Pérez

atelloru@ucm.es

Universidad Complutense de Madrid

\title{
Hacia un concepto de la secuencia (o prosa) litúrgica medieval ${ }^{*}$
}

\section{Towards a Concept of the Medieval Liturgical Sequence (or Prose)}

La secuencia es una clase de canto medieval que, situada por regla general entre el Alleluia y el Evangelio de la misa, fue empleada para festividades particulares en el seno de la liturgia franco-romana. Sin tener un carácter universal y preceptivo, estilísticamente tampoco puede decirse que pertenezca al repertorio gregoriano "clásico", aunque esté interrelacionada con él. De hecho, en el vasto corpus que hace de la secuencia la categoría de canto más prolífica de la Edad Media, una variabilidad de estilos y tipos (por ejemplo, puede existir como melodía sin texto, parcialmente textuada o como melodía y texto en su totalidad, generalmente a base de pareados), todavía hoy, han hecho de ella fuente de discrepancias y polémicas entre la crítica moderna a la hora de esclarecer y explicar su realidad como género. Este artículo tiene el propósito de contribuir a aclarar el concepto, uso y significado de la secuencia (o prosa) a partir, entre otras cosas, de la consideración de su naturaleza pluridimensional, sus distintas morfologías y estilos, su razón de ser y su posición de influencia en el culto franco-romano y fuera de él.

Palabras clave: secuencia (prosa), canción litúrgica medieval, canto gregoriano, Alleluia, misa franco-romana, género musical, forma musical, estilo musical, lexicografía.

The sequence is a kind of Medieval chant generally situated between the Alleluia and the Gospel in the Mass. It was used for certain feasts in the Roman-Frankish liturgy. Although it was not uniform or prescriptive in nature, stylistically it did not belong to the "classic" Gregorian repertory either, despite being interrelated with it. In fact, in the vast corpus that makes the sequence the most prolific chant of the Middle Ages, a variability of styles and types (for example, it can be a melody without text, partially set to text or melody and text throughout, generally made of couplets) have made it a source for discrepancies and polemics among modern critics still today when clarifying and explaining this genre. This article aims to shed light on the concept, use and

* Este trabajo ha sido realizado en el marco del proyecto de I+D+i "Espacio, letra e imagen: la Iberia medieval y el impacto de Cluny en el arte, la arquitectura y la liturgia" del Ministerio de Ciencia e Innovación (RTI2018-098972-B-100). 
meaning of the sequence (or prose) by considering such issues as its multidimensional nature, different morphologies and styles, fundamental purpose and its position of influence in the Roman-Frankish liturgy and beyond.

Keywords: sequence (prose), Medieval liturgical song, Gregorian chant, Alleluia, RomanFrankish Mass, musical genre, musical form, musical style, lexicography.

Antes de comenzar la empresa de tratar de definir, clarificar y entender qué es una secuencia como género litúrgico, literario y musical de la Edad Media, aunque no sea lo acostumbrado metodológicamente hablando, conviene que dediquemos unas brevísimas palabras para reparar en todo aquello que, en realidad, esta categoría de canto comparte con otras afines.Vayamos, pues, primero a lo que tiene de común, a lo que no la individualiza y distingue.

Con un corpus de más de cuatro mil quinientos ítems, el más profuso del mundo medieval latino, como tropos, prósulas, dramas litúrgicos, oficios versificados, conductus, versus y un largo etcétera que integra una realidad que bien podemos intitular "canción litúrgica medieval", la secuencia se integra en la liturgia franco-romana sin pertenecer al repertorio gregoriano -digámoslo asíclásico. Es una invitada en el rito. El motivo deviene en propiedad: no es universal, tampoco preceptiva. Pertenece a los estratos cambiantes, electivos, ornamentales del canto litúrgico, pero, incluso en ello, se hace acreedora y depositaria de arbitraje del principio retórico del ornatus dentro de la celebración de una solemnidad determinada, que pasa así a ser concebida y adaptada desde un punto de vista más próximo, cercano, local, regional. A través de la secuencia, pues, queda abierta una claraboya para el estudio y comprensión de las transferencias culturales y la configuración de los perfiles regionales durante la Edad Media, frente a la deliberada homogeneidad de la cantinela romana. Pero ornatus no implica tan solo embellecer u ornamentar, sino también -o sobre todoexplicar, profundizar, hacer exégesis de comprensión de una condición inherente a la acción litúrgica en sí misma: tratar de llegar a lo que queda humanamente vedado de la Palabra divina, revelada en las Escrituras y cantada en el corpus gregoriano, y posicionar al cristiano para participar de manera razonable del sacrificio de la misa.

De lo cambiante y lo electivo, por tanto, y no tan claro de lo estable y permanente, brotan intenciones, aportaciones y órdenes que se constituyen como una "forma dinámica", lo cual no es sinónimo perfecto de que lo variable no se relacione con lo duradero, pues un río no puede ser sin su cauce. Al contrario: variatio delectat, decía Cicerón. La secuencia, en su complejidad multidimensional, se relaciona necesariamente con el canto gregoriano; no tendría sentido sin él.

Comprendamos, entonces, su concepto, sus características y condiciones, para lo cual marcaremos una hoja de ruta que va desde la definición y significado del género (es decir, su raison d'être, que nosotros hemos denominado “forma lógica”), 
hasta una exposición de las principales características de sus diferentes estilos (un heterogéneo repertorio temprano, uno de transición y otro que arranca en el siglo XII o "clásico"), pasando por la decisiva y discutida reflexión en torno a su relación con el Alleluia, antes del Evangelio de la misa. En todo ello, elementos tales como la comprensión medieval del género y sus tradiciones, la relación entre melodía y texto (cuando lo hay) o las posibilidades interpretativas y formales (secuencia pareada, aparalela y de texto parcial), se tornarán en constantes indispensables a seguir en nuestra exposición. Así, por solo citar un efecto ilustrativo de este planteamiento, que los textos de las secuencias tempranas estuvieran en una prosa poética, a expensas de quedar organizada o moldeada por la melodía, ya fuese con una estructura pareada o no, será un factor determinante en tanto que mutó hacia una versificación rítmica que, en las secuencias de transición y del siglo XII en adelante, hacía que fueran las unidades poéticas las que definieran con frecuencia buena parte del comportamiento melódico. Sin más dilación, comencemos ahora nuestro recorrido.

\section{Definición y significado}

De manera genérica, la voz secuencia se emplea en la historia de la música y en la literatura de la Edad Media latina para referirse a un canto que siguió frecuentemente al Alleluia en la misa del rito franco-romano. No obstante, su forma y concepción fueron variando desde sus primeros testimonios, en el siglo IX, hasta su eliminación tácita en el Concilio de Trento $(1545-1563)^{1}$, de manera que no es posible encontrar una definición unitaria de su estructura, uso o función que se haya mantenido uniforme en todas las épocas y regiones de su desarrollo.

Esto significa que, al igual que sucede con otras categorías de canto litúrgico medieval, cualquier intento de sintetizar su definición solo con criterios taxonómicos, ya sea en una dimensión histórica, práctica y/o estética, resulta una empresa dificil y poco efectiva, por la imposibilidad misma de hacer una determinación unívoca y contrastante para la secuencia como género en términos modernos ${ }^{2}$. La manera medieval de clasificar los materiales y la

\footnotetext{
${ }^{1}$ Aunque no existiera una prohibición expresa para las secuencias en los decretos conciliares, con la aparición en 1570 del Missale Tridentinum, durante el papado de Pío V, solo se conservaron, por tradición, popularidad y/o prestigio, cuatro de ellas: Victimae paschali laudes, para la Pascua y su infraoctava; Veni Sancte Spiritus, para Pentecostés y su infraoctava; Lauda Sion Salvatorem, para Corpus Christi, y Dies irae, para el Día de Difuntos (2 de noviembre) y la misa de Requiem. Todavía una quinta secuencia, Stabat Mater dolorosa, fue recuperada en 1727 por Benedicto XIII para la festividad de los Siete Dolores de la BMV (15 de septiembre). Véase, por ejemplo, Edith Weber: Le Concile de Trente et la Musique. De la Réforme à la Contre-Réforme, París, Librairie Honoré Champion, 1982, p. 123.

${ }^{2}$ Para una reflexión análoga sobre una categoría comparable de canción litúrgica, véase Arturo Tello Ruiz-Pérez: "El significado de tropo desde la concepción de género en el mundo medieval", Revista de Musicología, 29, 1, 2006, pp. 45-58.
} 
lógica que la rige, resulta obvio, no es la nuestra.A cambio, y solo en términos operativos, conscientes de ello, lo que sí podemos hacer ahora es enumerar algunas características más o menos sostenidas, repletas de excepciones y matizaciones, en aras de configurar una hipótesis de estudio y de partida con la que abordar el "estilo" secuencia. A saber: la posición litúrgica entre Alleluia y el Evangelio, una estructura de pareados con melodías autónomas (o paralelismo progresivo) y la relación predominantemente silábica entre el texto y la melodía. Más allá de las generalizaciones de esta hipótesis inicial, hemos de asumir que la secuencia, en cuanto a concepto y significado, sigue siendo todavía hoy un "género" cargado de preguntas por responder. Como dice van Deusen, "a pesar de una considerable literatura concerniente a la secuencia, el tipo sigue siendo enigmático. Quedan en la penumbra: una función litúrgica basada en algo más significativo que la convención, su contenido espiritual y su significado intrínseco"”.

Quizá sea en esta penumbra de interrogantes donde se halle la verdadera "forma lógica" de la secuencia, es decir, una abstracción conceptual reconocible en cada una de sus proyecciones y manifestaciones, por diversas que estas puedan resultar entre ellas ${ }^{4}$. Dado que, como decíamos, la reducción a una serie de características formales, aun siendo importante y útil como hipótesis de estudio de la que partir -por su alto índice de excepciones, anomalías y hasta paradojas-, no es consistente del todo para semejante empeño; la cuestión es dónde buscar.

A este propósito, el rastreo de su posible origen ha sido un lugar común de la crítica, la cual, curiosamente, ante el arreciar de las complejidades, ha tratado de encontrar explicaciones en parámetros y aserciones característicos de otras disciplinas. Así, en la amplia historiografia del estudio de la secuencia, por momentos, no es extraño encontrar a la filología abandonándose a los caminos de la musicología y de la liturgia; a la musicología, a los laberintos filológicos de la retórica y de la crítica textual; a la liturgia, a los de la teología y la historia; y así sucesivamente.

Sin pretender hacer aquí ni mucho menos un estado de la cuestión ${ }^{5}$, para ilustrar esta realidad baste citar a Karl Strecker - uno de los editores de los Monumenta Germaniae Historica- cuando, tomando la sequentia como un fenómeno

\footnotetext{
${ }^{3}$ Nancy van Deusen: "The Use and Significance of the Sequence", Musica Disciplina, 40, 1986, p. 5: "Despite a considerable literature concerning the sequence, the type remains enigmatic. Unclear are: a liturgical function based on something more meaningful than convention, its spiritual content, its intrinsic significance". En adelante, salvo indicación contraria, todas las traducciones son nuestras.

${ }^{4}$ Empleamos aquí la noción de "forma lógica" en el sentido que le da Langer de ser un concepto abstraible y reconocible de la obra artística. Véase, por ejemplo, dado el carácter sintético de su pensamiento, Susanne K. Langer: Problems of Art. Ten Philosophical Lectures, Londres, Routledge \& Kegan Paul, 1957.

${ }^{5}$ Remitimos, por su completud, al realizado recientemente por Patricia Peláez Bilbao: Las secuencias del manuscrito Tortosa, Archivo Capitular, Cód. 135. Estudio y edición crítica, tesis doctoral, Universidad Complutense de Madrid, 2020, vol. 1, pp. 19-40.
} 
estrictamente melódico y original de prolongación de la última vocal del Alleluia, al recibir un texto, dice que:"contaba con tantas sílabas como notas tuviera el correspondiente fragmento melódico; por supuesto, este texto no tenía que ver con la poesía métrica ni con la rítmica, sino que era prosa pura, y así se llamó y se la sigue llamando en Francia" ". No obstante, lejos para él de ser inequívoco el concepto de prosa, a partir de la irrupción de la secuencia en el mundo medieval, Strecker establece que sus límites con respecto a la poesía se volvieron borrosos y liberadores. Encuentra en la posibilidad musical práctica de interpretar antifonalmente el pareado, el elemento catalizador e "innovador" de tal circunstancia:"la innovación hizo época porque fue aquí donde [la poesía] aprendió a quitarse los grilletes de los escasos esquemas métricos y rítmicos tradicionales"".

Por drástica o necesitada de matices que pueda parecernos esta noción de Strecker, denota una consideración de privilegio para la secuencia desde el universo de la literatura, como lo demuestra que, tal consideración, fuera llevada hasta el paroxismo por parte de Ernst Robert Curtius. En su influyente monografia sobre la literatura en la Edad Media latina, situando "su cuna rodeada de Musas", el filólogo alsaciano se abandona al hecho musical para proponer sin ambages una decisiva aserción seminal para el género: "la secuencia: he ahí el origen de la poesía moderna, a partir del espíritu de la música"8.

En una línea parecida, von den Steinen ${ }^{9}$ aceptó el aspecto de la interpretación musical del pareado como un elemento definidor para la secuencia, pero ello no le impidió, como a Strecker o después a Curtius, otorgar a Notker la mayor parte del mérito en lo que a la idea de la secuencia se refiere. Tal asunción, por lo demás, directamente de mano de von den Steinen, sería la asumida por Raby ${ }^{10}$, en la revisión de su historia de la poesía cristiana latina. Asimismo, Hans Spanke ${ }^{11}$ creyó que era en las influencias

\footnotetext{
${ }^{6}$ Karl Strecker: "Mittellateinische Dichtung in Deutschland", Reallexikon der deutschen Literaturgeschichte, Paul Merker, Wolfgang Stammler (eds.), Berlín, De Gruyter, 1926-1928, vol. 2, p. 391: "Der ebenso viele Silben zählte wie das entsprechende Stück der Melodie Töne; dieser Text berührte sich natürlich weder mit metrischer noch mit rythmischer Dichtung, sondern war reine Prosa, in Frankreich wurde und wird er auch so bezeichnet".

${ }^{7}$ Ibid.: "Die Neuerung war deshalb von epochemachender Bedeutung, weil man hier zum erstenmal lernte, sich von den Fesseln der wenigen überkommenen metrischen und rhythmischen Maße freizumachen.

${ }^{8}$ Ernst Robert Curtius: Literatura europea y Edad Media latina, México, Fondo de Cultura Económica, 1955, vol. 1, p. 220.

${ }^{9}$ Wolfram von den Steinen: Notker der Dichter und seine geistige Welt, Berna, Francke Verlag, 1948, vol. 1, p. 86 .

${ }^{10}$ Frederic James Edward Raby: A History of Christian-Latin Poetry from the Beginnings to the Close of the Middle Ages, Oxford University Press, 1953, pp. 210-219.

11 Hans Spanke: Beziehungen zwischen romanischer und mittelalterlicher Lyrik, mit besonderer. Berücksichtigung der Metrik und Musik, Berlín, Weidmann, 1936, pp. 74-103.
} 
combinadas de la música secular y de los himnos bizantinos donde habría que buscar la génesis de la secuencia; opinión compartida por Peter Dronke $^{12}$, sobre todo en lo que concierne a ese impulso de lo secular, y que fue tomada de los planteamientos pioneros de Wilhem Meyer ${ }^{13}$, centrados especialmente en la posible raíz litúrgica oriental.

Del otro lado, pasando entre otros por trabajos paradigmáticos como los de Peter Wagner ${ }^{14}$ (inclinado hacia la hipótesis de que los modelos de la liturgia bizantina debieron influir en la escuela de Sankt Gallen), como uno de los principales representantes de los estudios musicológicos, Richard L. Crocker ${ }^{15}$ señaló su naturaleza excepcional e independiente de la secuencia en cuanto a estructura, pero mantuvo una posición ambivalente en lo que respecta a sus orígenes: si bien, por un lado, la situó como un fruto heredero de la retórica clásica, por otro, la consideró un modelo formal genuinamente carolingio.

Toda esta carencia de resultados concluyentes, quizá se deba a que el intento de definir formalmente el género y de esclarecer sus orígenes, per se, no sea el paso más adecuado para dar en primer lugar. De manera que, tal y como investigadores de la importancia de Bruno Stäblein o el mismo Crocker han enfatizado repetidamente ${ }^{16}$, la necesidad más apremiante en las investigaciones acerca de la secuencia no es otra más que la del análisis. Sin embargo, a falta de una edición crítica y científica de todos los textos y/o melodías que permita una visión de conjunto (de manera similar a lo que ha supuesto la edición de Corpus Troporum [CT] en el campo de los

\footnotetext{
${ }^{12}$ Peter Dronke: "The Beginnings of the Sequence", Beiträge zur Geschichte der deutschen Sprache und Literatur, 87, 1965, pp. 43-73.

${ }^{13}$ Wilhem Meyer: Gesammelte Abhandlungen zur mittellateinischen Rythmik, Berlín, Weidmann, 1905, vol. 2, pp. 94-100.

${ }^{14}$ Peter Wagner: Einführung in die gregorianischen Melodien, ein Handbuch der Choralwissenschaft. 1. Ursprung und Entwicklung der liturgi schen Gesangsformen bis zum Ausgange des Mittelalters, Leipzig, Breitkopf \& Härtel, 1911, pp. 248-276.

${ }^{15}$ Richard L. Crocker: The Early Medieval Sequence, Berkeley, University of California Press, 1977, pp. 2, 421 .

${ }^{16}$ Bruno Stäblein: "Sequenz", Die Musik in Geschichte und Gegenwart, Friedrich Blume (ed.), Kassel, Bärenreiter-Verlag, 1965, vol. 12, col. 522-549; - : "Zur Frügeschichte der Sequenz", Archiv für Musikwissenschaft, 18, 1961, pp. 1-33; Richard L. Crocker: "Some Ninth-Century Sequences", Journal of the American Musicological Society, 20, 1967, pp. 367-402; —: The Early Medieval Sequence, p. 426. Actualmente, el análisis de ejemplos particulares se ha convertido en un procedimiento habitual de exposición, como puede verse, por ejemplo, en David Hiley: Western Plainchant. A Handbook, Oxford, Oxford University Press, 1993, pp. 172-195; Margot E. Fassler: Gothic Song. Victorine Sequences and Augustinian Reform in Twelfth-Century Paris, Cambridge, Cambridge University Press, 1993; Lori Kruckenberg: "Sequence", The Cambridge History of Medieval Music, Mark Everist, Thomas Forrest Kelly (eds.), Cambridge, Cambridge University Press, 2018, pp. 300-358; Arturo Tello Ruiz-Pérez: "Tras el rastro de tropos y prosas en el Codex Calixtinus. Una cuestión de método", Quodlibet, 75, 1, 2021, pp. 131168; Arturo Tello Ruiz-Pérez, Patricia Peláez Bilbao: "La prosa Gratulemur et laetemur. Una edición crítica", Quodlibet, 75, 1, 2021, pp. 221-271.
} 
tropos $)^{17}$, es una tarea difícil el intentar inducir características generales y válidas de únicamente algunos ejemplos particulares. A pesar de ello, el trabajo con estos ejemplos es importante, ya que nos permitirá poco a poco el esclarecimiento de una definición -aun a modo de hipótesis, como venimos haciendo- a partir de ciertas características más o menos persistentes. Así, convencidos de este beneficio, sumemos ahora algunas características más de las que señala, por ejemplo, Carmen Julia Gutiérrez:

Sus textos son poemas libres en latín no tomados de la Biblia que se organizan en parejas de dos líneas de texto con el mismo número de sílabas que se cantan con la misma melodía, siendo cada pareja diferente a la precedente en melodía y en la primera época también en número de sílabas del texto. En las primeras secuencias - hasta ca. 1000- no hay rima ni patrones acentuales: están en prosa. Los textos son del propio, dedicados a santos o fiestas particulares ${ }^{18}$.

Pues bien, son cantos de "nueva composición" y, aunque sabemos con certeza que la secuencia se sitúa de forma regular después del Alleluia y del versículo de su salmo, justo antes del Evangelio en la celebración de la misa solemne ${ }^{19}$, ello fundamenta plantear una cuestión adicional acerca de su función y posición dentro de esta que, a buen seguro, ayudará a dilucidar su naturaleza particular y "forma lógica" en el contexto global de la canción litúrgica medieval.Y todavía subyacente a esta cuestión, una premisa: "la idea principal es que hay un género, el de la misa" ${ }^{20}$, tal cual la establecieron convincentemente Ritva Jacobsson y Leo Treitler. La ventaja de esta imagen de la noción medieval de género litúrgico es que nos permite conjugar una cosa con otra, es decir, el papel individual de la secuencia con el hecho de que, para la Edad Media latina, el depósito principal y nutriente de textos para la misa siempre fuera la Biblia, en general, y el Libro de los Salmos, en particular.

La secuencia, por tanto, dentro del cohesionado ámbito de la acción litúrgica, viene a ser un canto nuevo entretejido e integrado en el complejo telar exegético de la Palabra divina. Así las cosas, aunque los textos de las secuencias no procedan ni tengan relación directa con los salmos, sí se ha

17 Ritva Jonsson et al:: Corpus Troporum, 12- vols., Estocolmo, Almqvist \& Wiksell, 1975-. Por supuesto, aun con cierta obsolescencia metodológica, aún es muy útil la edición de textos de los volúmenes consagrados a la secuencia por parte de los Analecta Hymnica (en adelante, AH). Guido Maria Dreves, Clemens Blume, Henry Marriott Bannister: Analecta Hymnica Medii Aevi, 55 vols., Leipzig, O. R. Reisland, 1886-1922, de manera monográfica los volúmenes 7-10, 34, 37, 39-40, 42, 44, 53-55.

${ }^{18}$ Carmen Julia Gutiérrez: "Secuencia", Diccionario de la música española e hispanoamericana, Emilio Casares Rodicio (dir.), Madrid, SGAE, 1999-2002, vol. 9, p. 879.

${ }^{19}$ En ocasiones también en otros lugares de la liturgia, por ejemplo, como sustituto del himno de Vísperas. Véase nota 45.

${ }^{20}$ Ritva Jacobsson, Leo Treitler: "Tropes and the Concept of Genre", Pax et Sapientia: Studies in Text and Music of Liturgical Tropes and Sequences in Memory of Gordon Anderson, Ritva Jacobsson (ed.), Estocolmo, Almqvist \& Wiksell International, 1986, p. 86: "The main idea is that there is one genre which is that of the mass". Véase también A. Tello Ruiz-Pérez: "El significado de tropo...". 
visto que comparten con ellos ciertas características tanto formales como conceptuales ${ }^{21}$. En efecto, ambas tipologías suelen tener versos paralelos, que varían en longitud según el pareado; todos los salmos y secuencias son de diferentes longitudes; $y$, en el caso concerniente a las primeras secuencias, en plena efervescencia de concepción del género, se les suma el hecho de estar en prosa, como los salmos de la Biblia latina. De igual manera, tanto los unos como las otras contienen con frecuencia frases "intercambiables", que migran de un salmo a otro o de una secuencia a otra, y en ambos géneros son frecuentes las expresiones de alabanza, particularmente aquellas relacionadas con instrumentos y, en especial, con la cithara, de importante significado alegórico para la época patrística y medieval. Justo este tópico de alabanza sin palabras, sería enfatizado con asiduidad en la secuencia por indicación o exhortación, en muchos casos literal, de interpretar la melodía sin texto o en alternancia con una versión textuada ${ }^{22}$.

En realidad, este último aspecto deja al descubierto un rasgo no mencionado hasta ahora en nuestra definición: la existencia de un tipo de secuencia puramente melódica. Sírvanos tal circunstancia de coexistencia entre las secuencias melódicas y textuadas, a la espera de volver sobre ella, para hacer en este punto un breve apunte lexicográfico. Si bien, por un lado, las secuencias melódicas recibieron varias denominaciones en la Edad Media, sequentiae, melodiae, iubili, pneumae, neumatum distinctiones o, ya en el siglo XIII, caudae (en tiempos modernos han sido llamadas también sequela $e^{23}$ ), por otro, el caso de las secuencias con texto, prosae, es más complicado ${ }^{24}$. Como veremos más adelante, la manera diferente de agrupar, escribir o copiar las secuencias en las tradiciones Este y Oeste del Imperio (desde que en el Oeste coexistían los sequentiaria,

${ }^{21}$ W. von den Steinen, Notker der Dichter..., pp. 90-106, 140-143; N. van Deusen, "The Use and Significance...", pp. 7-8.

${ }^{22}$ Una actualización del tema en Lori Kruckenberg: "Neumatizing the Sequence. Special Performances of Sequences in the Central Middle Ages", Journal of the American Musicological Society, 59, 2, 2006 , pp. 243-317. Para una visión del sentido simbólico de unión en el Alleluia-secuencia entre la Iglesia Militante y la Triunfante a partir de los comentarios de San Agustín, especialmente en Enarrationes in Psalmos, véase Balbino Martín Pérez (ed.): Obras de San Agustín. Enarraciones sobre los Salmos [bilingüe], Madrid, Biblioteca de Autores Cristianos, 1964-1967, vols. 19-22. Véase abajo, igualmente sobre esta cuestión, el comentario de Amalario de Metz en su Liber officialis (ca. 830).

${ }^{23}$ No antes del siglo XVII, como ya atestiguan el término las palabras del cardenal cisterciense Bona: "Ab alijs Sequentiae dictae sunt; quia sunt quaedam veluti sequela, et appendix cantici Alleluia, quae sine verbis post ipsum sequitur". Joanne Bona: Rerum liturgicarum libri duo, Roma, Typis Nicolai Angelii Tinassii, 1671, II, 6, 5, p. 335. Un ejemplo más moderno y paradigmático de esta denominación es la edición de melodías, a partir de los papeles de Bannister, de Andrew Hughes (ed.): Anglo-French Sequelae. Edited from the Papers of the Late Dr. Henry Marriott Bannister, Burnham, The Plainsong \& Medieval Music Society, 1934.

${ }^{24}$ Para una discusión sobre los significados de la voz "prosa" en el mundo medieval, véase Eva Odelman: "Comment a-t-on appelé les tropes? Observations sur les rubriques des tropes des $\mathrm{X}^{\mathrm{e}}$ et $\mathrm{XI}^{\mathrm{e}}$ siècles", Cahiers de Civilisation Médiévale, 18, 1975, pp. 15-36. 
colecciones solo de melodías, y los prosaria, colecciones de secuencias con texto y música; en el Este, en cambio, salvo excepciones, nunca existieron elencos únicamente de melodías de secuencia), ha determinado el juicio moderno hasta tal grado que, ni siquiera es que no resulte sencillo hacer una definición del género, sino ya incluso solo tener claro con qué término designar al propio género. Así, lo señala Margot E. Fassler:

En el presente, los investigadores franceses, frecuentemente denominan las versiones textuales como "prosas" y los alemanes e ingleses las denominan "secuencias".Y aunque algunos investigadores modernos han defendido la "prosa" para las versiones textuales y "sequentia" para las no textuales, en realidad el término "prosa" no se utilizó consistentemente, ni siquiera en fuentes francesas hasta después del siglo XIII"

Queda patente el embrollo terminológico existente entre la crítica; muy sintomático. La distinción de tradiciones y la heterogeneidad del empleo medieval de las voces sequentia y prosa (es posible encontrar en las rúbricas incluso la locución "sequentia cum prosa"), plantean que la opción más razonable sea la de aceptar que el empleo de los términos "secuencia" o "prosa", cuando la manifestación comporta tanto texto como melodía, sean parejos, si no sinónimos.

Así lo refleja el mismo título de este ensayo: secuencia o prosa, consecuentemente. Pero entonces... ¿ ¿por qué, entre los años 856 y 862, Notker Balbulus tituló a su colección de secuencias Liber Hymnorum, cuando hoy creemos tener clara la diferencia que existe entre un himno y una secuencia? Un conato de respuesta a este interrogante podríamos buscarlo en el prefacio o Prooemium de su obra (véase abajo), donde alude al propósito de ayudar a su memoria para justificar la necesidad de poner palabras a esas melodiae longissimae procedentes de Jumièges, como si recurriese simplemente a un término familiar -himno- para referirse a la "nueva realidad"-la secuencia- que tenía delante. Ahora bien, si consideramos el hecho de que los salmos eran los himnos del Antiguo Testamento, del pueblo de Israel, y que con ellos los acólitos se iniciaban en la lectura y la escritura, en el canto y en el aprendizaje en sí mismo (por lo que constituyeron uno de los estratos más asentados en la memoria), pareciera ser como si Notker, perfecto conocedor, por ejemplo, de la Expositio psalmorum de Casiodoro ${ }^{26}$, se estuviese refiriendo a las secuencias como a los "nuevos salmos".

${ }^{25}$ M. E. Fassler: Gothic Song..., pp. 42-43: "In the present age, French scholars usually call the texted versions 'proses', and German and English scholars call them 'sequences'. And although some modern scholars have advocated 'prosa' for the texted versions and 'sequentia' for the untexted, actually the term 'prosa' was not used consistently even in French sources until after the thirteenth century".

${ }^{26}$ Para una explicación de todas las similitudes en cuanto a pensamiento y formulación entre el Liber Hymnorum de Notker y la Expositio Psalmorum de Casiodoro, véase N. van Deusen: "The Use and Significance...", pp. 25 y ss. 
Esta suposición, en principio un poco ambigua, cobra todo su sentido en el momento en el que se aduce como razón la masa tremenda de comentarios que los salmos inspiraron de principio a fin de la Edad Media. El motivo, no es otro más que la coyuntura de que los salmos estén repletos de alusiones alegóricas que requieren ser explicadas. Así, a causa de su lenguaje alegórico y de su estilo, los salmos constituyeron un verdadero puente entre el Antiguo y el Nuevo Testamento y, más concretamente, puede decirse que anticiparon o prefiguraron el Evangelio.

No es de extrañar, pues, que David, el salmista por antonomasia, se convirtiera en una figura clave tanto en la interpretación de las Escrituras como en salvar el espacio existente entre lo viejo y lo nuevo. Además de rey, él es el celebrante, el bailarín, el cantante y el tañedor ante Dios; el converso arrepentido y ungido que, preferido, habría de gobernar nada menos que al "pueblo elegido".Y siendo una personalidad del Antiguo Testamento, no obstante, personifica una "nueva liturgia" que se cumplirá en Cristo.

Es en este sentido en el que Carlomagno, en su afán de unificar su Imperio a través precisamente de la liturgia, se identificaría como el nuevo David ${ }^{27}$ y, en el seno de su reforma, evidentemente esos "nuevos salmos" a los que parecía referirse Notker encajarían a la perfección. De esta manera, David es frecuentemente mencionado en los textos de las secuencias como psalmista, citharista y como rey, y si echásemos una mirada pormenorizada a $\operatorname{estos}^{28}$, se desvelaría que el enlace entre el Antiguo y el Nuevo Testamento, de manera análoga a los salmos, fue modelado, no solo textual, sino también musicalmente por la secuencia dentro del contexto de la misa. No en vano, sequentia (de sequens - $t i$ ) quiere decir "lo siguiente", "lo que sigue", "lo que viene después", "continuación”. Así pues, en la celebración, la transición entre el Antiguo Testamento (el Alleluia con su versículo cantado) y el Nuevo Testamento (la proclamación del Evangelio) está articulada por medio de la secuencia.Y revestida con frecuencia de un lenguaje alegórico muy similar al propio de los salmos, los temas centrales de los textos son aquellos que parten de un concepto veterotestamentario resuelto y clarificado en las Nuevas Escrituras ${ }^{29}$.

${ }^{27}$ Sea suficiente al respecto aludir ilustrativamente al hecho de que, en la corte de Aquisgrán, Carlomagno era llamado por el nombre de David, como testimonian las alabanzas mesiánicas ("rey David", "mi amado David"...) de Alcuino de York hacia él en sus escritos. Véanse ejemplos en Ernst Dümmler (ed.): Epistolae Karolini aevi. 2. Epistolae 4, Munich, Monumenta Germaniae Historica, 1978.

${ }^{28}$ Compruébese, aun reducido al ámbito lemosino, en Lars Elfving: Étude lexicographique sur les séquences limousines, Estocolmo, Almqvist \& Wiksell, 1962; o, con un enfoque netamente teológico, en Guillermo Javier Karcher: Las antiguas secuencias lemosinas de los tiempos fuertes del año litúrgico. Valoración teológico-litúrgica del Prosario de Analecta Hymnica VII, tesis doctoral, Pontificio Instituto Litúrgico de Roma, 1998.

${ }^{29}$ Una indicación de la importancia de la unificación entre el Antiguo y Nuevo Testamento en los escritos patrísticos y medievales, así como en la liturgia, es dada en Henri de Lubac: Exégèse médiévale. Les quatre sens de l'Écriture, París, Aubier, 1959, vol. 1, pp. 328 y ss. 
Por consiguiente, la secuencia puede ser definida como una categoría de canto litúrgico medieval que se erige en la primera parte de la misa como el punto de "transmisión", de mezcla y coordinación, así como de introducción de armonía entre elementos, en principio, dispares. Y aquí radica su "forma lógica", en una conectividad modelada sobre los salmos. En efecto, significa conexión, une lo viejo con lo nuevo, pero también establece una mezcolanza entre modos textuales y estilos musicales, a tenor de que ella misma encarna un alma melódica dúplice, textuada y no textuada. Los mismos textos abundan en alusiones referentes a las cualidades complementarias de la verbalización y de la expresión mística sin texto ${ }^{30}$.

En definitiva, como fruto del espíritu renovador del mundo cultural carolingio, la secuencia representa el paradigma de síntesis de la renovatio litúrgica carolingia, donde quizá se fundan también el gusto del canto galicano con la imposición oficial del rito romano. Sin embargo, no hay que olvidar que, desde nuestra manera contemporánea de ver las cosas, debemos hacer siempre un esfuerzo para entender hasta el fondo todo lo que la secuencia representa como género.Y en este sentido se manifiesta Treitler, cuando afirma que:"una íntima relación entre el estilo y la función ritual es un aspecto de la música medieval tan ajeno a nuestras tradiciones, que hemos tenido que acostumbrarnos a ella mediante un esfuerzo consciente" 31 .

De esta manera, a través de este "esfuerzo consciente" y de un reposado análisis de los ejemplos particulares, tenemos que ciertas características constantes de la secuencia fueron sugeridas por los salmos, de forma que su estilo y función estuvieron determinadas por su papel de transición. Porque bien puede decirse que la secuencia fue, ante todo, un canto de transición, un nexo entre el Antiguo y el Nuevo Testamento y entre estilos literarios y musicales diversos, en la misma medida que su naturaleza quedó negociada y definida a través de referencias sólidas, en cuanto a sentido y cualidad, al Alleluia y al Evangelio de la misa.

\section{Alleluia, secuencia, Evangelio}

Más allá de las convenciones, por tanto, si la secuencia puede quedar mejor definida a través de un valor que por una serie de características técnicas o formales, es decir, aquel de ser pura conectividad, transición, continuidad entre el

${ }^{30}$ La mixtura es especialmente evidente en algunas fuentes que dan secuencias tanto con texto como sin él, y la práctica no queda limitada a las fuentes más tempranas. Véase, por ejemplo, Ecce puerpera genuit en el manuscrito gerundense del siglo XV, Barcelona, Bibl. de Catalunya, ms. 911, ff. 48r-49r, la cual, siendo una secuencia parcialmente textuada, alterna melodía textuada y no textuada.

${ }^{31}$ Leo Treitler: The Aquitanian Repertories of Sacred Monody in the Eleventh and Twelfth Centuries, tesis doctoral, Princeton University, 1967, vol. 1, p. 2: "An intimate relationship between style and ritual function is an aspect of medieval music so foreign to our own traditions that we have had to accustom ourselves to it through conscious effort". 
Alleluia y el Evangelio, encontrando su raison d'être en el universo referencial a ambos momentos litúrgicos, uno cantado en un estilo melismático y otro cantilado silábicamente, esclarecer su posición intersticial como "aquello que sigue" es algo que se vuelve un imperativo en términos relacionales, diríamos que hasta de esencia.Tratemos de ahondar ahora, entonces, en dichas relaciones.

A lo largo de toda la Edad Media, especialmente hasta finales del siglo XIII, uno de los puntos álgidos en lo que al desarrollo musical se refiere en el transcurso del día litúrgico se concentró sin duda en la primera parte de la misa. Fue justo en este lugar, entre las lecturas y el Evangelio, donde los solistas por regla general dieron rienda suelta a sus más notables y elaborados recursos interpretativos para cantos particularmente melismáticos, como el Gradual o el Alleluia. En este punto fue en el que, a menudo, como una práctica local, algunas iglesias añadieron una antífona en las fiestas más solemnes del año como prefacio al Evangelio, y, al menos desde el siglo IX, también fue este el espacio reservado para el canto de las secuencias. Sin embargo, fuera cual fuera el caso, la función tanto del texto como de la música de todos estos cantos parecía tener siempre un solo horizonte último: anunciar la proclamación del Evangelio por parte del diácono o del celebrante.

Por otro lado, el hecho de que, ya en el siglo IX, el Alleluia carolingio fuera fundamentalmente un canto tripartito formado por el canto del Alleluia de manera melismática, por el versículo (en ocasiones muy floreado y adornado), cuyo texto procedía con frecuencia del Libro de los Salmos, y la repetición del Alleluia, revalorizó el carácter simbólico del iubilus (continuación melismática de la melodía del Alleluia en la última sílaba de la palabra) y de toda una suerte de melodiae longissimae añadidas a este canto ${ }^{32}$. Así, por tanto, los melismas venían a representar los sonidos angélicos del Paraíso a los que el cristiano se uniría en el canto justo en el lugar donde las palabras ya no pueden llegar. Precisamente los comentarios de San Agustín a los salmos vinieron a dar un soporte teológico a esta concepción y otorgan una justificación litúrgica para inclusión de ciertos añadidos ${ }^{33}$ :

Cantadle cántico nuevo; cantadle bien. Cada uno pregunta cómo ha de cantar a Dios. [...] Canta con regocijo [iubilatione], pues cantar bien a Dios es cantar con regocijo. ¿Qué significa cantar con regocijo? Entender, porque no puede explicarse

32 Sobre la configuración del canto del Alleluia durante los siglos VII, VIII y IX, véase James McKinnon: The Advent Project. The Later-Seventh-Century Creation of the Roman Mass Proper, Berkeley, University of California Press, 2000, pp. 249-279.

${ }^{33}$ Aunque restringiendo su valor al final melismático del Alleluia y no tanto a las sequentiae, véanse las interesantes conclusiones a las que llega McKinnon a este respecto y que sitúan al obispo de Hipona como fundamento de autoridad primordial. James McKinnon: "The Patristic Jubilus and the Alleluia of the Mass", Cantus Planus. Papers read at the Third Meeting of the International Musicological Society Study Group, Tihany, Hungary, 19-24 September 1988, László Dobszay, Péter Halász, János Mezei, Gábor Prószéky (eds.), Budapest, Hungarian Academy of Sciences Institute for Musicology, 1990, pp. 61-70. 
con palabras lo que se canta en el corazón. [...] El júbilo [iubilum] es cierto cántico o sonido con el cual se significa que da a luz el corazón lo que no puede decir o expresar. [...] ¿qué resta sino que te regocijes, para que se alegre el corazón sin palabras y no tenga límites de sílabas la amplitud del gozo? Cantadle bien con regocijo [iubilatione] ${ }^{34}$.

Revestido, pues, con todo su carácter simbólico, el Alleluia ocupó un lugar especial en el conjunto de los cantos de la misa franco-romana, gozando de un extraordinario desarrollo en cuanto al número de melodías y, en ocasiones, en cuanto a la extensión de estas, al tiempo que una misma melodía podía ser adaptada a diversos versículos y festividades. Sea como fuere, y pese a su naturaleza responsorial, no era en la práctica una respuesta a las lecturas, máxime con la aparición puntual de un segundo versículo de salmo, sino un verdadero preludio al Evangelio.

Fue precisamente el perfil estilístico de los Alleluias el que en buena medida determinó todas las clases e intentos de exégesis litúrgica asociados con este canto, de manera que el estilo de esos "comentarios" añadidos (ya sean melódicos y/o textuales) siempre estuvo condicionado por la naturaleza propia de cada Alleluia. No obstante, también se dio la curiosa circunstancia de que los mismos añadidos frecuentemente remodelaron el Alleluia para hacer de él una más clara representación de todo lo que el mundo carolingio entendía englobado en este canto -especialmente a la luz de comentarios como los de San Agustín-; por lo que, como dice Calvin M. Bower, sobre todo en el caso de las secuencias, sería más apropiado emplear el término "interdependencia” entre Alleluia y añadido que el de "dependencia" 35 . De este modo, en época carolingia y postcarolingia, parece que todos los tipos de adiciones al Alleluia, ya sean prosulae, melodiae longissimae (sequentiae) o secuencias/prosas (texto y música), en muy buena medida vinieron a situarse como un medio de profundización en el significado litúrgico del canto como la manifestación musical de los sonidos de exultación máxima (hallĕlu-Yăh > "Alabad a Yaveh") hechos por los ángeles ${ }^{36}$.

\footnotetext{
${ }^{34}$ Texto y traducción tomada de B. Martín Pérez (ed.): Obras de San Agustín. 19..., pp. 435-436: "Cantate ei canticum novum: bene cantate ei. Quaerit unusquisque quomodo cantet Deo. [...] In iubilatione cane: hoc est enim bene canere Deo, in iubilatione cantare. Quid est in iubilatione canere? Intelligere, verbis explicare non posse quod canitur corde. [...] Iubilum sonus quidam est significans cor parturire quod dicere non potest. [...], quid restat nisi ut iubiles; ut gaudeat cor sine verbis et immensa latitudo gaudiorum metas non habeat syllabarum? Bene cantate ei in iubilatione". [Las cursivas no son nuestras]. Una traducción parcial puede encontrarse asimismo en Giulio Cattin: Historia de la Música 2. El Medioevo. Parte I, Madrid, Turner Música, 1987, pp. 161-162.

${ }^{35}$ Calvin M. Bower: "An Alleluia for Mater", Essays on the Music of J. S. Bach and Other Divers Subjects. A Tribute to Gerhard Herz, Robert L. Weaver (ed.), Nueva York, Pendragon Press, 1982, p. 111: "Rather than describe the sequence as 'dependent' on the Alleluia, I would describe both melodies as being "interdependent"'.

${ }^{36}$ Reinhold Hammerstein: Die Musik der Engel. Untersuchungen zur Musikanschauung des Mittelalters, Berna, Francke, 1962, pp. 39-47.
} 
El versículo del Alleluia toca el interior del cantor, de forma que piensa de qué manera alabar a Dios o cómo regocijarse. Este regocijo [iubilatio], que los cantores llaman secuencia [sequentiam], lleva a nuestra mente hacia ese estado en el que no será necesario pronunciar las palabras, sino que, por el mero pensamiento, la mente mostrará a la mente lo que contiene ${ }^{37}$.

Como vemos, Amalario de Metz, alrededor del año 830, hizo en su Liber officialis una descripción de una elaboración melódica, sin palabras, que llevaría a los cantores a un estado extático -muy agustiniano en espíritu- después del versículo del Alleluia ${ }^{38}$. De forma curiosa, este arrebato contemplativo de cantores y fieles, con un sentido ascensional, suspendería las valencias del lenguaje discursivo, incluso en su dimensión poética, para devolverlo con toda su potencia precisamente al más elevado reino de la Palabra, el del Evangelio. El nivel exegético de cohesión que Amalario otorgó a la secuencia, evidenciaría por sí sola una conciencia de concepción alrededor de muchos de los valores definitorios del género.

Dicha elaboración melódica, iubilatio, que "los cantores llaman sequentia", parece corresponderse con una clase de pieza especificada en un gradual de finales del siglo VIII, proveniente de Mont Blandin ${ }^{39}$. Después del último domingo de Pentecostés, se copia en este manuscrito una lista de veinticinco Alleluias entre los que seis ${ }^{40}$, después del versículo, llevan la rúbrica "cum sequentia" ${ }^{41}$.Algunas décadas más tarde del testimonio de Amalario, encontraríamos

${ }^{37}$ Jean-Michel Hanssens (ed.): Amalarii episcopi Opera liturgica omnia, Roma, Biblioteca Apostolica Vaticana, 1948-50, vol. 2, p. 304: "Versus alleluia tangit cantorem interius, ut cogitet in quo debeat laudare dominum, aut in quo laetari. Haec iubilatio, quam cantores sequentiam vocant, illum statum ad mentem nostram ducit, quando non erit necessaria locutio verborum, sed sola cogitatione mens menti monstrabit quod retinet in se".

${ }^{38}$ Del mismo modo, en el quinto Ordo Romanus, escrito en algún lugar de las tierras del Rin entre los años 850 y 900 (para uso tanto monástico como secular), encontramos una referencia similar a la de Amalario: "Cantor vero qui inchoat Alleluia, ipse solus cantat versum de Alleluia. Ipse iterum Alleluia dicit, stans in eodem gradu, id est inferiore. Sequitur iubilatio, quam sequentiam vocant [En verdad, el cantor que entona el Alleluia, canta él mismo el versículo del Alleluia. Él mismo dice (canta) una vez más el Alleluia, de pie en el mismo escalón, es decir, el inferior. Sigue la iubilatio, que llaman secuencia (sequentiam)]". Michel Andrieu (ed.): Les Ordines Romani du Haut Moyen Âge. Les Textes (Ordines I-XIII), Lovaina, Spicilegium Sacrum Lovaniense, 1948, vol. 2, p. 215. La inclusión de la sequentia en un Ordo Romanus es una prueba explícita de la asimilación de la secuencia dentro del rito franco-romano. Otro testimonio del s. IX, en De Harmonica Institutione de Hucbaldo de Saint-Amand, a través de una breve referencia a la secuencia Stans a longe como ejemplo de canto gregoriano, vuelve a demostrar la asunción de la secuencia como parte del rito. Véase Warren Babb: Hucbald, Guido and John on Music. Three Medieval Treatises, New Haven, Yale University Press, 1978, pp. 28-30.

${ }^{39}$ Bruselas, Bibl. Royale, Cod. lat. 10127-10144 (ca. 780-820). Véase René-Jean Hesbert: Antiphonale Missarum Sextuplex, Bruselas, Vromant, 1935, p. 199a. De manera sinóptica (especialmente en la Tabla 10.1, pp. 309-310) y discusión sobre más testimonios, directos e indirectos, de entre ca. 800 a 925, en L. Kruckenberg: "Sequence", pp. 304-317.

${ }^{40}$ Estos seis Alleluias son Iubilate Deo, Dominus regnavit, Beatus vir, Te decet hymnus, Cantate DominoNotum fecit Dominus y Confitemini Domino.

${ }^{41}$ Stäblein, a partir del estudio de algunos manuscritos posteriores, ha demostrado que, efectivamente, todos estos Alleluias fueron cantados con alguna clase de añadido. Véase B. Stäblein: "Zur Frügeschichte der Sequenz", pp. 4-7; R. L. Crocker: The Early Medieval Sequence..., pp. 392-395. 
el ya citado prefacio del Liber Hymnorum de Notker, donde se hace una descripción de unas melodiae longissimae y del proceso de poner texto a estos embellecimientos del Alleluia para poder recordarlas más fácilmente, casi a manera de una suerte de notación musical en sí misma (véase nota 64).

Lo que inmediatamente se desprende de estos testimonios es que, ya a mediados del siglo IX, ese género de melodías mencionadas por Amalario y cantadas en la abadía de Mont Blandin creció y se desarrolló en algunos lugares hasta el punto de poner a prueba la memoria de los acólitos ${ }^{42}$. Por otro lado, es más que probable que las textualizaciones de las melodiae longissimae existieran antes del tiempo de Notker: tan solo sería necesario citar su afirmación de que él mismo tomó esta idea de los ejemplos, ya muy "corruptos", del antifonario perteneciente al monje huido del saqueo de Jumièges o el reposado conocimiento de su maestro Iso a la hora de corregirle y ayudarle. Pero un canon que podría haber sido dictado por un concilio celebrado en Meaux en el año 845, da una clara prueba de que la práctica referente a que los cantores, tanto seculares como regulares, añadieran textos a las sequentiae para el Alleluia, estaba ya muy extendida a mediados del siglo IX, puesto que no se sanciona algo que no esté generalizado:

Debido a la reprobable iniquidad de algunos, que deleitándose en las novedades, no temen alterar [interpolare] la pureza de la antigüedad con sus propias invenciones, establecemos que ningún clérigo o monje ose añadir, interpolar, recitar, murmurar o cantar cualquiera de las composiciones, que llaman prosas, o cualesquiera otras fantasias [fictiones], en el himno angélico, es decir, el Gloria in excelsis Deo, y en las secuencias, que suelen cantarse solemnemente en el Alleluia. El que así lo haga, sea destituido ${ }^{43}$.

La indicación de que debía prohibirse la alteración del canto del Gloria y de la sequentia, por medio de diversos procedimientos y composiciones textuales conocidas como prosae, es muy importante, ya que refleja la primera oposición

${ }^{42}$ R. L. Crocker: The Early Medieval Sequence..., pp. 396-397, donde se establece que no hay manera de saber qué ocurrió exactamente en el tránsito del siglo VIII al siglo IX en relación con este repertorio. También es significativa, en esta dinámica, la cita de que en una copia posterior del Liber officialis de Amalario, la secuencia aparezca ya como un capítulo aparte: De sequentia.

${ }^{43}$ Wilfried Hartmann (ed.): Concilia Aevi Karolini, Hanover, Hahn, 1984, vol. 3, p. 129: "Propter inprobitatem quorundam omnino dampnabilem, qui novitatibus delectati puritatem antiquitatis suis adinuentionibus interpolare non metuunt, statuimus, ut nullus clericorum nullusque monachorum in ymno angelico, id est Gloria in excelsis deo, et in sequentiis, quae in Alleluia sollempniter decantari solent, quaslibet compositiones, quas prosas vocant, vel ullas fictiones addere, interponere, recitare, submurmurare aut decantare presummat. Quod si fecerit, deponatur". Para una discusión en torno a este canon véase Gabriel Silagi: "Vorwort", Liturgische Tropen. Referate zweier Colloquien des Corpus troporum in München (1983) und Canterbury (1984), Munich, Arbeo-Gesellschaft, 1985, pp. 8-10; Keith A. Falconer: Some Early Tropes to the Gloria, tesis doctoral, Princeton University, 1989; Andreas Haug: "Ein neues Textdokument zur Entstehungsgeschchte der Sequenz", Festschrift Ulriche Siegele zum 60. Geburtstag, Rudolf Faber (ed.), Kassel, Bärenreiter Verlag, 1991, pp. 3-19. 
explícita entre los términos sequentia y prosa por el mero hecho de que la invención del texto pudiera corromper el rito. En este sentido, las sequentiae parecen ser tratadas como poseedoras de un valor intrínseco por su pureza de antigüedad, por lo que se entiende que tenían ya en estas fechas un lugar claro dentro de la misa gregoriana.

A pesar de la enumeración de algunos de estos testimonios tempranos en torno al Alleluia y a la secuencia, lo cierto es que la relación de ambos géneros no queda en absoluto clarificada a partir de ellos o, al menos, no lo hace bajo el prisma de nuestra concepción moderna de las cosas. Si bien, por un lado, como dice Gutiérre $z^{44}$, no se puede afirmar en líneas generales que la secuencia derive absolutamente del Alleluia o que sea un tropo de este, idea relacionada con el mito de un gregoriano original y auténtico que fue "tropado" o alterado con posterioridad, por otro lado, si examinamos con detenimiento cierta información aportada por los manuscritos, es posible dar cuenta de la existencia de algunos elementos que realmente vinculan la secuencia al Alleluia.

En primer término, podemos apuntar que al menos existe una relación nominal, en el sentido de que debajo de la primera frase de las melodías que están anotadas de forma melismática en los sequentiaria, aparece la palabra "alleluia". Aun así, se trata de una relación puramente nominativa que no tiene por qué tener que ver ni con la prosa (texto) correspondiente a esa secuencia, ni implica que tenga que existir obligatoriamente una relación melódica entre la primera frase de esta y un Alleluia del propio de la misa. Lo que sí que es innegable es que existe una filiación litúrgica entre ambos géneros, desde el mismo momento en el que, como ya hemos tratado arriba, la secuencia servía de conexión y de exégesis entre el Alleluia y el Evangelio, entre elViejo Testamento y el Nuevo o, lo que es lo mismo, entre la promesa hecha a los profetas y su cumplimiento en Cristo. Pero es que, además, como dice Bower:

Ambos géneros se cantan en el momento de la misa en el que más anomalías y libertad existen; ambos géneros existen como melodías independientes del texto y, por tanto, ambos pueden adaptarse a varias ocasiones específicas. La necesaria asociación litúrgica entre las dos formas está tal vez mejor ejemplificada por la desaparición de la secuencia durante la Cuaresma, cuando no se cantan Alleluias ${ }^{45}$.

${ }^{44}$ C. J. Gutiérrez: "Secuencia”, p. 879

${ }^{45}$ C. M. Bower: "An Alleluia for Mater", p. 110: "Both genres are sung at that moment in the Mass in which most anomalies, and most freedom, occur; both genres exist as melodies independent of text, and thus both can be adapted to various specific occasions. The necessary liturgical association between the two forms is perhaps best exemplified by the disappearance of the sequence during Lent when no Alleluias are sung". En efecto, al igual que el Alleluia, la secuencia podía ser adaptada a diferentes festividades e, incluso, ocasiones litúrgicas, como lo demuestra el hecho de que, fuera de la misa, fuese cantada en el oficio, especialmente reemplazando al himno de Vísperas, en las Completas o al final de Maitines (en algunas tradiciones también durante la Vigilia Pascual y Pentecostés), sin contar con que algunos dramas litúrgicos la absorbieron (así el caso de Victimae paschali laudes para el drama pascual Quem quaeritis in sepulchro). En algún momento entre el 831 y el 855, un ejemplo temprano de ello nos lo da de nuevo 
En el intento de esclarecer la posición litúrgica de la secuencia, muchos investigadores han caído en la tentación de emparentar este género con otros de canción litúrgica medieval que, en ocasiones, no resultan ser del todo exactos con aquello que se entendía por sequentia o prosa en la Edad Media temprana. Quizá el testimonio más notorio en este sentido sea el de Jacques Handschin, cuando afirma que la secuencia:

Es una subsivisión del tropo: es el tropo conectado con el Alleluia de la misa -o, de manera más precisa, el tropo añadido al Alleluia cuando se repite después de su versículo-. Desde que la secuencia llegó a ser particularmente prominente, el término "tropo", que propiamente incluye a la secuencia, también se utiliza, en un sentido más restringido, para indicar cualquier tipo de tropo que no sea una secuencia. Hasta aquí la terminología no está en disputa ${ }^{46}$.

Evidentemente, esta suposición implicaría la existencia previa de una melodía a la que posteriormente se le añadiría el texto mediante el proceso de "tropar" o, más propiamente, "prosular" (de prosula -ae, es un verbo que utilizamos aquí de manera exclusiva y parcial para designar la acción de adaptar un texto al melisma dado de una composición gregoriana) ${ }^{47}$ el iubilus de un Alleluia determinado. Para Handschin, por tanto, la alusión a la secuencia implicaría tanto la melodía sin texto como con él, a pesar de que la unión de texto y música, como hemos visto, en ocasiones también haya sido definida como prosa en un elevado número de manuscritos medievales. El desarrollo de esta

Amalario de Metz, esta vez en el Liber de ordine antiphonarii, cuando da cuenta de la presencia del canto de la secuencia en el contexto de las Vísperas de la semana de Pascua en Roma: "Ideo in ea statione in qua apostolicus celebrat vespertinale officium, alleluia canitur cum omni supplemento et excellentia versuum et sequentiarum [Por tanto, en esta estación en la que el Papa celebra el oficio vespertino, que se cante el Alleluia con todo boato y excelencia de los versículos y las secuencias]". Jean-Michel Hanssens (ed.): Amalarii episcopi Opera liturgica omnia, Roma, Biblioteca Apostolica Vaticana, 1948-50, vol. 3, p. 84. Siglos más tarde, en este mismo sentido encontramos también una interesante rúbrica en la consueta ausonense Vic, Bibl. Mus. Episc., ms. 134, f. 5v, del siglo XIII (ca. 1216-1228): "Dum dicitur prosa non dicatur uersus neque hymnus [Siempre que se diga la prosa, que no se diga ni versus ni himno]". Higini Anglès: La música a Catalunya fins al segle XIII, Barcelona, Biblioteca de Catalunya, 1935, p. 220.

${ }^{46}$ Jacques Handschin: "Trope, Sequence and Conductus", New Oxford History of Music. 2. Early Medieval Music up to 1300, Anselm Hughes (ed.), Londres, Oxford University Press, 1954, p. 128: "Is a subdivision of the trope: it is the trope connected with the Alleluia of the Mass - or, more precisely, the trope added to the Alleluia when it is repeated after its verse. Since the sequence became particularly prominent, the term 'trope', which properly includes sequence, is also used, in a more restricted sense, to indicate any kind of trope which is not a sequence. So far the terminology is not in dispute". El influjo del argumento de Handschin ha ponderado la consideración de la secuencia por buena parte de la crítica. Valga como demostración el comienzo del capítulo correspondiente a la secuencia en el popularizado manual de Hoppin, escrito en 1978: "Como adiciones al Aleluya de la Misa, las secuencias han sido consideradas por lo general como una clase especial de tropo". Richard H. Hoppin: La música en la Edad Media, Madrid, Ediciones Akal, 2000, p. 168.

${ }^{47}$ Arturo Tello Ruiz-Pérez: "Tropo", Diccionario de la música española e hispanoamericana, Emilio Casares Rodicio (dir.), Madrid, SGAE, 1999-2002, vol. 10, pp. 478-484. 
hipótesis, asimismo, supondría que la secuencia viniera a ser un reemplazamiento con texto añadido o no del iubilus. Esto significaría que la estructura de los pareados y otras características formales se derivarían de una supremacía del hecho melódico previo, quizá a modo de emulación del impulso que otorgaron otros desarrollos del Alleluia, como la adición de nuevos versículos y me$\operatorname{lodías}^{48}$. Bajo el punto de vista de Handschin, no solo existiría una relación entre Alleluia y secuencia, sino una supeditación en la que la segunda en todo momento estaría sujeta "estructural" o "constitutivamente" al primero.

Muy lejos de esta concepción, Crocker, ya desde sus primeras aportaciones, ha puesto en duda que necesariamente fuera la preexistencia de la melodía la que diera origen a la secuencia, y ha mantenido otra hipótesis de índole divergente, en la que cabría la posibilidad de que, en dichos orígenes, texto y música fueran compuestos de manera simultánea, minimizando la importancia de la relación Alleluia-secuencia ${ }^{49}$ y centrándose en el lenguaje "elevado" de las prosae ("Kunstprose"), como un principio formativo crucial en el género. Hay que consignar, sin embargo, que gran parte de las conclusiones aportadas por Crocker, y este es un dato no poco relevante al respecto, se han derivado sobre todo del estudio de dieciséis manuscritos conservados en la Biblioteca Nacional de París, de los siglos X y XI, procedentes todos del ámbito de Saint Martial de $\operatorname{Limoges}^{50}$ o, lo que es lo mismo, del grueso del corpus de secuencias aquitano-occidentales.

Con todo, entre el conjunto de conclusiones principales de Crocker al estudiar ese repertorio temprano, se halla el hecho de identificar tres tipos de estructura a partir de los incipit de las prosas, hoy en día de gran utilidad a la hora de acercarse al análisis de estas piezas ${ }^{51}$. A saber:

1. Cuando una primera línea individual de texto tiene su correspondiente frase melódica, y a esta le siguen otro par de líneas con su melodía correspondiente (la segunda línea del pareado tiene la misma longitud

\footnotetext{
${ }^{48}$ Sobre estas supuestas relaciones melódicas, véanse los estudios de Heinrich Husmann: "Das Alleluia Multifarie und die vorgregorianische Stufe des Sequenzgesanges", Festschrift Max Schneider zum achtzigsten Geburtstage, Walther Vetter (ed.), Leipzig, Deutscher Verlag für Musik, 1955, pp. 17-23; —: "Alleluia, Vers und Sequenz", Annales Musicologiques, 4, 1956, pp. 19-53; etc. Muy esclarecedor, asimismo, en cuanto a los problemas que plantea este aspecto, resulta Calvin M. Bower: "Alleluia, Confitemini Domino, Quoniam Bonus - An Alleluia, Versus, Sequentia, and Five Prosae Recorded in Aquitanian Sources", Music in the Theater, Church and Villa: Essays in Honor of Robert Lamar Weaver and Norma Wright Weaver, Susan Parisi (ed.), Warren, Míchigan, Harmonie Park Press, 2000, pp. 3-30.

${ }^{49}$ Aspecto central en los estudios sobre la secuencia hasta la fecha. Por su importancia en este sentido (mención especial merecen los estudios de Stäblein, el ya nombrado Husmann y un no escaso etcétera), véase una actualización bibliográfica en Calvin M. Bower: "From Alleluia to Sequence. Some Definitions of Relations", Western Plainchant in the First Millennium. Studies in the Medieval Liturgy and its Music, Sean Gallagher (ed.), Burlington, Ashgate, 2003, pp. 351-398; L. Kruckenberg: "Sequence", pp. 350-356.

${ }^{50}$ Richard L. Crocker: The Repertory of Proses at Saint Martial de Limoges (Tenth and Eleventh Centuries), tesis doctoral, Yale University, 1957.

${ }^{51}$ Richard L. Crocker: "The Repertory of Proses at Saint Martial de Limoges in the Tenth Century", Journal of the American Musicological Society, 11, 1958, pp. 149-164.
} 
y melodía que la primera). La estructura sería la siguiente: XY1Y2, de manera que la "X" es la línea individual y la "Y1Y2" son las dos líneas que forman el pareado.

2. Cuando existe una relación melódica de la primera frase con un Alleluia específico de la misa. En tal caso, la estructura sería: (All) XY1Y2. Estructuralmente no existe diferencia con el tipo anterior, solo se distinguen en que, en el segundo, la primera frase tiene la melodía tomada de un Alleluia.

3. Cuando las prosas comienzan directamente con un pareado regular (teniendo la misma longitud y melodía) de estructura Y1Y2. Con esta configuración, en el secuenciario, suele aparecer una frase melódica haciendo la función de introducción al pareado, frase frecuentemente subrayada por la palabra "alleluia". La estructura, entonces, sería: All Y1Y2. Sin embargo, esta primera frase colocada con la palabra "alleluia" debajo, podía ser o no ser similar o idéntica al incipit de un Alleluia de la misa. Es decir, que en la primera frase aparezca la palabra "alleluia", no implicaría la existencia de relación real con un Alleluia.

Justamente esta última conclusión, constatando que algunas melodías de secuencia no hacen referencia a ningún Alleluia conocido, ha sido la que ha permitido a Crocker argumentar que la creencia tradicional acerca de la creación de las secuencias no es del todo verdadera ${ }^{52}$ :

Esta posición litúrgica, combinada con la tradición de llamarla sequentia y con la práctica de escribir las melodías de secuencias sin texto, como melismata, cada una comenzando con el texto "Alleluia", proyectaba la imagen de la secuencia como un remplazo textual para el jubilus; pero hay demasiadas discrepancias para que la imagen sea creíble.Y hay secuencias tempranas y prototípicas que no se ajustan a esta imagen ${ }^{53}$.

Aun siendo verosímil la hipótesis lanzada por Crocker, es decir, que en muchos casos no se partió de un Alleluia particular para crear una secuencia, sin embargo, como apunta Fassler, parece que esta cuestión, la del Alleluia-secuencia, fue un motivo intenso de preocupación para los francos hasta el punto de que,

\footnotetext{
${ }^{52}$ R. L. Crocker: The Early Medieval sequence..., pp. 392-409.

${ }^{53}$ Richard L. Crocker: "Medieval Chant", New Oxford History of Music. 2. The Early Middle Ages to 1300, Richard L. Crocker, David Hiley (eds.), Oxford, Oxford University Press, 1990, pp. 258-259: "This liturgical position, combined with the tradition of calling it sequentia, and also the notational practice of writing down the sequence melodies without text, as melismata, each beginning with the text 'Alleluia', all projected the image of the sequence as a texted replacement for the jubilus; but there are too many discrepancies for the image to be believed. And there are some early and very typical sequences that not conform to the image". Asimismo, Crocker establece que la relación con el Alleluia se va haciendo más cercana en épocas posteriores. Véase R. L. Crocker: "The Repertory of Proses at Saint Martial...", pp. 160-161.
} 
aunque a veces no crearan secuencias partiendo de un Alleluia en concreto, no sea descabellado pensar que al menos pretendiesen dar la impresión de que sí lo hacían $^{54}$. Para Fassler, varios factores son fundamentales como argumento:

1. Las secuencias de los siglos IX y X tenían una estructura irregular y las sílabas parecían haber sido superpuestas sobre melodías preexistentes (lo que ocurre algunas veces).

2. A diferencia de las secuencias de Notker, la gran mayoría de las secuencias escritas en el sur de Francia durante los siglos X y XI sostienen la vocal 'a' de la palabra “alleluia” al final de sus líneas, reforzando la idea de que estas piezas son extensiones del Alleluia.

3. Los textos de la secuencia temprana de los siglos IX, X e, incluso, XI aluden como tema recurrente a la práctica explícita de añadir textos, bien a la música de la Iglesia Triunfante o de los ángeles, bien al sonido del órgano.

4. En los manuscritos, las secuencias normalmente aparecen escritas con un incipit de "alleluia" en el inicio, aunque las notas correspondientes no tengan ninguna relación conocida con un Alleluia de la liturgia.

5. Es apreciable que la tradición de escribir las secuencias de dos formas, con texto y sin él, se debiera probablemente a que la notación de las piezas sin texto ayudaría a leer la notación de la pieza con texto.

De esta manera, para Fassler, las secuencias tempranas debieron haber sonado como si de prosulae para el iubilus o para las sequentiae del Alleluia se tratara; de ahí, su implicación (necesaria) con el Alleluia de la misa. Propone dejar fuera de toda duda que la secuencia, en su naturaleza dual, melódica o textuada, asumió deliberadamente los valores simbólico-musicales del Alleluia y que, como comentario de este, demuestra como género cuán importante era el peso de la tradición de dichos valores para el compositor litúrgico medieval.

Algunos estudios realizados con posterioridad, han arrojado nueva luz sobre el tema, al tiempo que han planteado nuevos puntos vista. Así, por ejemplo, encontramos las investigaciones de David Hiley y las valoraciones concernientes a la relación crucial entre melodías y textos hechas por Andreas Haug. Si bien, a través del análisis de las variantes de las melodías de secuencia más tempranas y extendidas, Hiley ha demostrado que las melodías también eran interpretadas y diseminadas sin $\operatorname{textos}^{55}$, Haug considera

${ }^{54}$ M. E. Fassler: Gothic Song..., pp. 40-41.

${ }^{55}$ David Hiley: "The Sequence Melodies Sung at Cluny and Elsewhere", De musica et cantu. Studien zur Geschichte der Kirchenmusik und der Oper: Helmut Hucke zum 60. Geburtstag, Peter Cahn, Ann-Katrin Heimer (eds.), Hildesheim, Olms, 1993, pp. 131-155; —: "The Repertory of Sequences at Winchester", Essays on Medieval Music in Honor of David G. Hughes, Graeme M. Boone (ed.), Cambridge, Harvard University Press, 1995, pp. 153-193. 
los textos como textualizaciones, aunque en todo momento acentuando que la preexistencia de las melodías no necesariamente ha de ser interpretada como una relación histórica o cronológica, sino como una correspondencia desde el punto de vista técnico. Hemos aquí, por ejemplo, el sugerente término que, con carácter neutral, introduce para los desarrollos litúrgicos del Alleluia durante el siglo IX:"neuer Ansatz" [nuevo enfoque] ${ }^{56}$.

Hasta ahora, como podemos comprobar, todas estas posiciones y maneras de ver el vínculo o interrelación entre Alleluia y secuencia por parte de la crítica, han quedado circunscritas en su mayoría a determinar la identidad del incipit melódico de una secuencia -textuada o no, preexistente o coexistentecon el de un Alleluia o su iubilus; casi como un criterio único e insoslayable. Sin dejar en absoluto de lado este principio, pues es importante a nivel demostrativo, nosotros, ya desde la misma definición del género, de su "forma lógica", hemos razonado la hipótesis de que, en virtud de su significado inherente y la articulación exegética de su contenido -melódico y/o textual-, la secuencia queda fusionada inextricablemente con el Alleluia -mientras preludia y conduce al Evangelio- en ese marco genérico y aglutinante que es la celebración misma. La identificación de la correspondencia de incipit es reveladora, no cabe duda, igual que lo es la equivalencia nominativa con los versículos del Alleluia con los que pudiera relacionarse una secuencia dada, pero no son los únicos criterios empíricos.

Correspondencias de otra índole podrían buscarse y entrar en liza de manera muy ventajosa, como la equivalencia melódica y motívica en un espectro más amplio que el mero incipit, la consonancia y complementariedad de los sentidos exegéticos de la Escritura en la concatenación versículo-prosa-Evangelio (que, a su vez, comporta canto melismático-canto silábico-cantilación), o aquella de la asociación litúrgica y circunstancial en los intrincados procesos de migración -llenos de significado por sí mismos- de los Alleluias (y sus versículos asociados) de unas festividades a otras. Es obvio que, ninguna de estas dimensiones, excluye o desacredita a las otras.

Por fortuna, Bower ${ }^{57}$, en un estudio casi piloto en este sentido, ha abordado no hace demasiado tiempo la relación Alleluia-secuencia en el repertorio temprano del Este y del Oeste, desde el prisma de algunas de estas dimensiones. Se trata de una propuesta metodológica que reclama, por parte del autor, un estudio más pormenorizado, pero que, sobre la base de unas implicaciones relacionales de tipo litúrgico, histórico, musical y estético, ya arroja algunos resultados preliminares de sumo interés, tanto cuantitativo, a través de sus tablas, como cualitativo, en función de las viables líneas de investigación que deja abiertas.

\footnotetext{
${ }^{56}$ Andreas Haug: "Neue Ansätze im 9. Jahrhundert", Die Musik des Mittelalters, Hartmut Möller, Rudolf Stephan (eds.), Laaber, Laaber-Verlag, 1991, pp. 94-128; -: "Melisma", Die Musik in Geschichte und Gegenwart, Ludwig Finscher (ed.), Kassel, Bärenreiter-Verlag, 1997, vol. 6, pp. 19-29.

${ }^{57}$ C. M. Bower: "From Alleluia to Sequence...", pp. 351-398.
} 
Pues bien, la primera constatación de Bower es que, considerando en conjunto todos estos factores, la expectativa de relaciones Alleluia-secuencia crece de forma casi exponencial. Así, de un corpus de cincuenta melodías tempranas de secuencia en la tradición del Este, nada menos que veintiuna reciben su "apodo" 58 de uno o varios versículos de Alleluia (veintiséis es el total de versículos cuyo incipit sirve para nombrar sequentiae). A ellas se les suman otras siete por coincidencia de incipit melódico con Alleluias conocidos, además de once que establecen una asociación litúrgica consistente con determinados Alleluias. Es decir, treinta y nueve de cincuenta melodías de secuencia (prácticamente cuatro quintos del repertorio) guardan diversos grados de parentesco -no excluyentes- con algún Alleluia. Por su parte, las ciento cuarenta y dos melodías del Oeste se reparten a razón de sesenta y cuatro, con una denominación coincidente con alguno de los versículos de Alleluia (son cincuenta y tres los citados); treinta y tres, a tenor de su identidad compartida por el incipit melódico; y seis, alcanzan su vinculación por vía exclusiva de asociación litúrgica. Lo que nos da una proporción de dos tercios del repertorio para el Oeste, justo la misma que si consideramos ambas tradiciones como un conjunto.

Detrás de la fría objetividad de las matemáticas, no obstante, se esconden algunas consideraciones que Bower presenta a la manera de principios. Por ejemplo, "aquellas melodías de Alleluia que son cantadas más a menudo durante el año litúrgico tienden a ser asociadas con una pluralidad de melodías de secuencia" 59 , de lo que se sigue que la secuencia es, entre otras cosas, un medio efectivo de hacer propio (> appropriare) el instante previo a la proclamación del Evangelio, sobre todo cuando la melodía del Alleluia es demasiado común (entiéndase el hecho en el devenir de la necesidad de diferenciar una solemnidad específica del resto de los días). De hecho, la secuencia puede tornarse en un elemento clave para la identificación y datación de melodías de Alleluia que podrían haber venido directamente de Roma, ya que, por su asociación con ellas en otros manuscritos posteriores (si consideramos, con McKinnon ${ }^{60}$, que las contenidas en el manuscrito Roma, Bibl. Apostolica Vaticana, vat. lat. 5319 son el grupo más antiguo que se habría diseminado en territorio franco a mediados del siglo VIII), podría especularse con la existencia de secuencias que hubiesen viajado también desde Roma. Recordemos simplemente el testimonio de Amalario en el Liber de ordine antiphonarii (véase nota 45).

Desde el punto de vista estrictamente técnico-musical, de los datos ofrecidos por Bower, puede entresacarse que, pese a sus posibles vinculaciones motívicas en el incipit y/o desarrollo, la secuencia tuvo rango de

\footnotetext{
${ }^{58}$ Acerca de la costumbre medieval de titular con sobrenombres las melodías de secuencia, véase la breve discusión y bibliografía de L. Kruckenberg: "Sequence", pp. 322-324.

${ }^{59}$ C. M. Bower: "From Alleluia to Sequence...", p. 364: "Those Alleluia melodies that are most often sung during the liturgical year tend to be associated with a plurality of Sequence melodies".

${ }^{60}$ J. McKinnon: The Advent Project..., pp. 255-256.
} 
autonomía en cuanto a su desenvoltura -más expansiva y audaz- con respecto a la melodía de "su" Alleluia particular. Sin forzar las cosas, así lo demuestra el caso de encontrar diferentes melodías de secuencia para una única de Alleluia, es decir, maneras diversas de "interpretarlo" o de individualizarlo exegéticamente, lo que pone de manifiesto, por lo demás, que cada secuencia no es un mero suplemento melódico deslindado de un Alleluia concreto o un apéndice musical de este. El conocido testimonio de una glosa del siglo IX sobre el De nuptiis Philologiae et Mercurii, de Marciano Capella, cobra así nuevos significados y matices: hablando de una música, perteneciente al reino de la harmonia, establece que no necesita apoyarse en el significado de las palabras, "sino solo sonidos, que se unen conforme a alguna base racional, igual que las secuencias [sequentiae] entre los cantores" $"$.

A través del examen de los comentarios litúrgicos, de la información contenida en las fuentes y de los posicionamientos más relevantes de la crítica, podemos concluir dos condiciones significativas: a) que en los repertorios tempranos, camino al Evangelio, existieron firmes y demostrables lazos de unión entre el Alleluia y la secuencia; y b) que, a la luz de determinadas transformaciones estilísticas posteriores, las actitudes con respecto a la relación Alleluia y secuencia fueron susceptibles de cambio en el transcurso de la Edad Media. Por tanto, la secuencia, de ser vista desde sus orígenes hasta el siglo XII temprano como una especie de enganche con el Evangelio, "interdependiente" con el Alleluia y expresando las mismas cosas que él, ya en el siglo XII tardío, pasó a ser una composición de carácter más desligado del Alleluia, aunque -como veremos- todavía conservando gran parte de la carga simbólica de este, lo que no le impidió asumir nuevos valores y propósitos dentro de la liturgia, y también fuera. Se hace perentorio, pues, dar un paso más hacia la cuestión del estilo para comprender mejor el concepto de la secuencia en tanto que fenómeno dinámico.

\section{El estilo en el repertorio temprano}

Es muy dificil hablar de la secuencia primitiva sin volver, una vez más, al Liber Hymnorum de Notker, puesto que de este testimonio, a pesar de haber sido puesto en duda la verosimilitud del Prooemium ${ }^{62}$, se desprenden una serie de "claves" de vital importancia para interpretar el repertorio.

${ }^{61}$ Mariken Teeuwen: Harmony and the Music of the Spheres. The "Ars Musica" in Ninth-Century Commentaries on Martianus Capella, Leiden, Brill, 2002, pp. 327-328: "Sed soni tantum sibimet ipsis aliqua ratione coniuncti queruntur, ut sunt sequentiae apud cantores".

${ }^{62}$ Desde Blume en los AH, 53, p. xix, pasando por Spanke, Handschin, von den Steinen, Husmann, etc., han sido muchas las discusiones en favor y en contra de aceptar la autoría de Notker en el Prooemium, así como también ha sido puesta en tela de juicio la validez misma de este testimonio. En tiempos recientes, por ejemplo, R. L. Crocker: The Early Medieval Sequence...; - "Sequence", The New Grove Dictionary of 
En primer lugar, tenemos que las melodías empleadas por Notker pueden ser ubicadas con seguridad en el siglo IX. Casi todas las otras melodías en los grandes y confusos repertorios conservados en las fuentes de alrededor del año 1000 carecen de esta evidencia. Es cierto que algunas de ellas pueden datar del siglo IX, pero la mayoría probablemente no, y no hay manera alguna por entero objetiva para determinar cuál es cuál (solo Stans a longe, nombrada por Hucbaldo de Saint-Amand, podría ser considerada sin duda también del s. IX). Por tanto, una valoración fehaciente de las características comunes para un corpus de las secuencias más antiguas, en principio, únicamente podría ser alcanzada en base a las melodías usadas por Notker.

Además, incluso aunque la tradición melódica de Sankt Gallen no pueda ser completamente descifrada hasta varios siglos después de Notker, los textos del Liber Hymnorum suponen una inestimable herramienta para verificar el plan marcado para las secuencias en el siglo IX. Esto se debe al hecho de que, como regla general para el repertorio temprano, cualquier texto encaja solo con una melodía, mientras que una melodía dada siempre puede tener varios textos alternativos. De tal manera que incluso la disposición de una melodía que, expresada en el número y la longitud de sus frases, hubiera sido alterada entre el siglo IX y el tiempo en que por vez primera es conservada en una versión legible (generalmente no anterior al año 1000), siempre podría reestablecerse en su forma primitiva a partir del texto de Notker. En este sentido, el valor de este testimonio se torna de un valor decisivo para el repertorio temprano en su conjunto ${ }^{63}$, habida cuenta de que el repertorio occidental comparte sus más importantes melodías con el Liber Hymnorum de Notker: en la relativamente estable tradición de manuscritos de Sankt Gallen, las secuencias muestran solo pocos cambios entre aproximadamente el 850 y el 1000 (e incluso en centurias posteriores); en cambio, las secuencias occidentales muchas veces sufrieron variaciones.

Al que por su gran santidad se ha visto elevado al honor de ser un gran sacerdote, al amadísimo señor Liutwardo, el más digno sucesor de ese hombre incomparable, Eusebio, obispo de Vercelli; y abad del monasterio del santísimo Columbano y

Music and Musicians, Stanley Sadie (ed.), Londres, Macmillan, 1980, vol. 17, pp. 141-153, ha puesto en duda la validez histórica del prefacio, lo que ha sido debatido principalmente por A. Haug: "Ein neues Textdokument...", pp. 3-19, y sobre todo en Andreas Haug: "Re-Reading Notker's Preface", Quomodo cantabimus canticum? Studies in Honor of Edward H. Roesner, David Butler Cannata, Gabriela Ilnitchi Currie, Rena Charnin Mueller, John Louis Nádas (eds.), Middleton, Wisconsin, American Institute of Musicology, 2008, pp. 65-80. Véase también la reciente discusión de C. M. Bower: The Liber Ymnorum of Notker Balbulus, Londres, Henry Bradshaw Society, 2016, vol. 2, pp. 1 y ss.

${ }^{63}$ R. L. Crocker: "Sequence", pp. 141-153; —: R. L. Crocker: The Early Medieval Sequence..., pp. 1-14. 
defensor de la celda de su discípulo, el nobilísimo Galo y también archicapellán del gloriosísimo emperador Carlos, de Notker, el más insignificante de los monjes de San Galo.

Cuando aún era joven y las melodías muy largas -repetidamente confiadas a la memoria- escapaban de mi pobre cabeza, empecé a razonar cómo podría evocarlas con rapidez. Entretanto, sucedió que otro sacerdote de Jumièges, recientemente asolado por los normandos, vino a morar entre nosotros. Con él traía su antifonario, en el que aparecían ciertos versos puestos en música de secuencia, aunque se hallaban en un estado ya muy corrupto. Tanto como me habían deleitado a la vista me desilusionó su gusto. A pesar de esto, a imitación de esos versos empecé a escribir "Laudes Deo concinat orbis universus, qui gratis est redemptus" y más adelante, "Coluber adae deceptor". Cuando llevé los versículos a mi maestro Iso, este, tras alabar mi laboriosidad y sentir piedad por mi falta de experiencia elogió lo que era agradable y lo que no lo era decidió mejorarlo diciendo: "los movimientos individuales de la melodía deberían recibir sílabas individuales". Al escuchar tal cosa aquellos que caían bajo 'ia', los corregí sin tardanza. Sin embargo, aquellos bajo 'le' o 'lu' me parecieron casi imposibles y dejé de intentarlo, aunque más adelante, con la práctica lo resolví de manera fácil, como atestiguan "Dominus in Sina" y "Mater". Instruido de tal forma, pronto compuse mi segunda pieza, "Psallat ecclesia mater illibata". Cuando enseñé estos versículos a mi maestro Marcelo, este, lleno de alegría, los hizo reunir por escrito, y se los dio a algunos niños para que los cantaran. Cuando me dijo que debería recogerlas en un libro y ofrecerlas como presente a una persona eminente, me retraí avergonzado, ya que pensaba que jamás podría hacer tal cosa. Hace poco que mi hermano Otario rogó que alguien en vuestro honor se encargara de redactarlo y yo fui considerado merecedor de llevar a cabo esta obra singular. Finalmente y a duras penas me animé a ello y dedico este humilde e insignificante librito a vuestra nobleza para con ello ganarme vuestra piedad y para que (el libro) sirva de apoyo a mi hermano junto a nuestro señor el emperador.Vuelvo a usar obstinadamente el mismo metro en el que escribí la vida de San Galo -aunque mi hermano Salomón lo hubiera propuesto antes- para que lo examinéis y me apresuro a disponer lo que por vos ha de ser explicado ${ }^{64}$.

\footnotetext{
64 "Summae sanctitatis merito summi sacerdotii decore sublimato domino dilectissimo Liutwardo incomparabilis viri eusebii vercellensis episcopi dignissimo successori abbatique coenobii sanctissimi columbani ac defensori cellulae discipuli eius mitissimi galli necnon et archicapellano gloriosissimi imperatoris Karoli Notkerus cucullariorum Sancti Galli novissimus. Cum adhuc iuvenulus essem et melodiae longissimae, saepius memoriae commendatae, instabile corculum aufu gerent, coepi tacitus mecum volvere, quonam modo eas potuerim colligare. Interim vero contigit, ut presbyter quidam de Gimedia, nuper a Nordmannis vastata, veniret ad nos, antipho narium suum deferens secum: in quo aliqui versus ad sequentias erant modulati, sed iam tunc nimium vitiati. Quorum ut visu delectatus, ita sum gustu amaricatus. Ad imitationem tamen eorundem coepi scribere: Laudes deo concinat orbis universus, qui gratis est redemptus, et infra: Coluber Adae deceptor. Quos cum magistro meo Isoni obtulissem, ille studio meo congratulatus im peritiaeque compassus, quae placuerunt laudavit, quae autem minus, emendare curavit dicens: Singulae motus cantilenae singulas syllabas debent habere. Quod ego audiens, ea quidem quae in ia veniebant, ad liquidum correxi: quae vero in le vel lu, quasi inpossibilia vel attemptare neglexi, cum et illud postea usu facillimum deprehenderim, ut testes sunt 'Dominus in Syna' et 'Mater'. Hocque modo instructus, secunda mox vice dictavi: Psallat ecclesia mater illibata. Quos versiculos cum magistro meo Marcello praesenta rem, ille gaudio repletus in rotulas eos
} 
Aparte del hecho de que denomine a sus secuencias himnos y de que perfeccione, como iniciativa personal, un tipo de piezas que provienen de occidente (Jumièges), a partir del Proomeium vemos también que Notker concibe las sequentiae (melismas) relacionadas con la palabra "alleluia", esperando conservar tanto su contorno melódico como la estructura fonética de la palabra. Asimismo, entiende la elaboración de sus textos como textualizaciones "estrictas" de composiciones melódicas independientes y preexistentes, de manera que podemos deducir un trato de la prosa ("art-prose") como una categoría poética que en ningún caso tiene por qué ser inferior al versus $s^{65}$.

Más allá del testimonio de Notker, la secuencia en sus inicios muestra una gran diversidad de género, circunstancia evidenciada tanto en el texto como en la melodía, así como en la relación entre ambas. Los diferentes y variados ejemplos que se han encontrado en las primeras fuentes permiten entrever una poderosa y creativa imaginación de los autores, dejando como testimonios secuencias cuya estructura puede ser paralela o aparalela, que pueden existir con o sin texto, que a veces solo tienen parte de la melodía textuada y en los que la relación texto-música suele ser silábica ${ }^{66}$.

congessit; et pueris cantandos aliis alios insinuavit. Cumque mihi dixisset, ut in libellum compactos alicui primorum illos pro munere offerrem, ego pudore retractus numquam ad hoc cogi poteram. Nuper autem a fratre meo Othario rogatus, ut aliquid in laude vestra conscribere curarem, et ego me ad hoc opus imparem non immerito iudicarem, vix tandem ali quando aegreque ad hoc animatus sum, ut hunc mini mum vilissimumque codicellum vestrae celsitudini con secrare praesumerem. Quem si in eo placitum vestrae pietati comperero, ut ipsi fratri meo apud domnum im peratorem sitis adminiculo, metrum quod de vita sancti Galli elaborare pertinaciter insisto, quamvis illud fratri meo Salomoni prius pollicitus fuerim, vobis examinan dum, habendum ipsique per vos explanandum dirigere festinabo" (Einsiedeln, Stiftbibliothek, Codex 121, ff. 429-433). W. von den Steinen: Notker der Dichter ..., vol. 2, pp. 8-10; - : Notkeri Poetae. Liber ymnorum [Notkers des Dichters. Hymnenbuch], Berna / Munich, Francke Verlag, 1960, pp. 6-8: La traducción es de Carmen Julia Gutiérrez en la versión preparatoria (aunque finalmente no incluida en la versión definitiva) de la voz "Secuencia", del Diccionario de la música española e hispanoamericana, (agradecemos la amabilidad de habernos facilitado esta versión no publicada). Para una traducción publicada, aunque parcialmente, del Prooemium, véase Donald. J. Grout, Claude V. Palisca: Historia de la Música Occidental, Madrid, Alianza Música, 1997, vol.1, p. 82.

${ }^{65}$ A. Haug: "Re-Reading Notker's Preface", p. 70. Véase una actualización del particular en Sam Barret: "Latin Song at the Abbey of Sankt Gallen from c. 800 to the Liber Ymnorum", Early Music History, 38, 2019, pp. 1-50.

${ }^{66}$ Por ejemplo, como expone D. Hiley: Western Plainchant..., p. 186, en el Liber Hymnorum, encontramos cuarenta textos para treinta y tres melodías, de los cuales ocho son para ocho melodías breves y de estructura aparalela, sin que existan ejemplos de melodías parcialmente textuadas. Por otra parte, Chartres, Bibliothèque municipale, ms. 47 posee diez melodías aparalelas y tampoco ninguna parcialmente textuada, mientras que Pa 1240, el primer tropario-prosario completo conocido, contiene cuatro melodías parcialmente textuadas y ninguna aparalela. En todos los casos, el resto de secuencias tendrían una estructura paralela, lo que indica que fue esta la forma arquetípica o predominante ya en la secuencia primitiva. 


\section{La secuencia paralela}

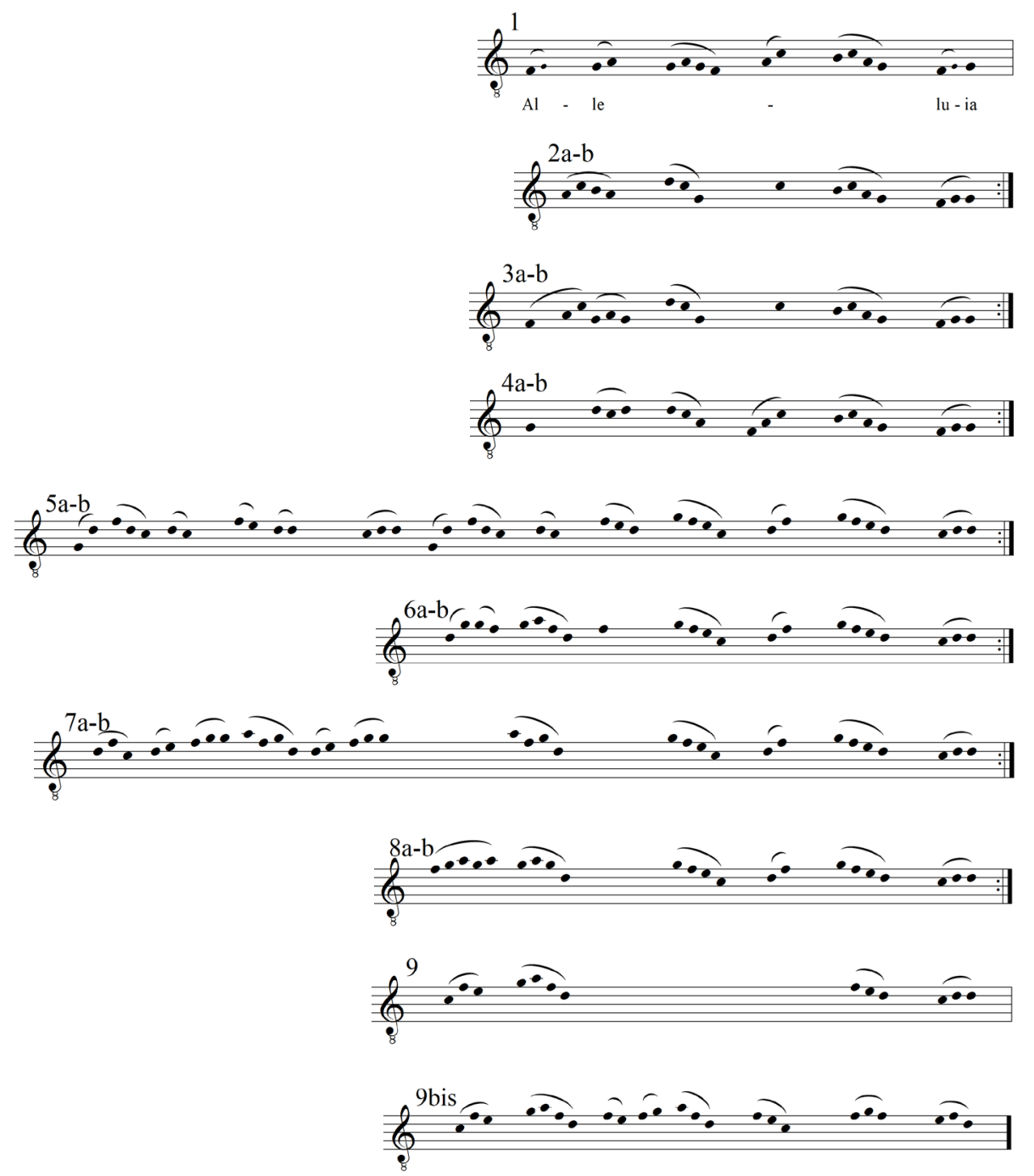

Ejemplo 1. Secuencia Mater, en Sankt Gallen, Stiftsbibl. Cod. 381, pp. 443-445, s. X (transcripción basada en la distematía de Einsiedeln, Stiftsbibl. Cod. 366 (Msc. 472), s. XII) ${ }^{67}$.

Véase ilustración 2

${ }^{67}$ Transcripción tomada de Haug en Gunilla Björkvall, Andreas Haug: "Sequence and Versus: On the History of Rhythmical Poetry in the Eleventh Century", Latin Culture in the Eleventh Century. Proceedings of the Third International Conference on Medieval Latin Studies, Cambridge (1998), Michael W. Herren, Christopher J. McDonough, Ross G. Arthur (eds.), Turnhout, Brepols, 2002, vol. 1, p. 71. 
El ejemplo 1 muestra una melodía de secuencia (sequentia) -llamada Mater, en el Este, y Christi hodierna / Caelica resonant, en el Oeste- tal y como aparece en los manuscritos de las áreas Este y Oeste a partir del siglo X. Esta sequentia consiste en nueve líneas melódicas que varían considerablemente en longitud: las más breves tienen trece o catorce notas; las más largas, treinta y cinco o treinta y siete; y la mayoría oscila entre las diecisiete y las veintidós. Esta peculiar combinación de líneas constituye la forma melódica de esta secuencia, forma que la hace diferente de cualquier otra secuencia.

A simple vista, es reseñable el hecho de que las frases primera y última -aunque emparentadas- sean simples, mientras que el resto están repetidas. Asimismo, la tremenda expansión de las frases 5 y 7 se debe a repeticiones internas, y se da la circunstancia de que todas las frases terminan con la misma figura cadencial (Fa-Sol-Sol y Do-Re-Re) ${ }^{68}$.

La melodía está basada sobre el modo de Sol, pero solo las frases 1-4 acaban en la finalis del modo, mientras que el ámbito melódico está restringido al marco del salto de quinta. A partir de la frase 6, la melodía parece desplegarse ascendentemente, y ya la figura cadencial se produce sobre la quinta superior, de forma que el clímax se alcanza en las frases 7 y 8 . Por otro lado, es destacable que la expansión gradual hacia el agudo de la melodía se corresponde con la expansión, también gradual, de la longitud de las frases, siempre con una sensación de dinamismo tendente a una meta cadencial (el hecho de que no sea habitual la sucesión de notas repetidas es muy significativa en este sentido). Finalmente, se puede vislumbrar una considerable concentración motívica entre algunas frases de la secuencia (por ejemplo, en las secciones finales entre las frases de la 1 a la 4 y de la 5 a la 8); en esta dinámica, el despliegue de la composición melódica podría decirse que se produce principalmente en los comienzos de frase, mientras que la coherencia siempre suele conseguirse en las secciones finales.

Esta sequentia ha sido copiada -y, aparentemente, también podría haber sido interpretada- sin texto (véase ilustración 3), es decir, como una composición meramente melismática, pero la evidencia explícita de una interpretación no textuada de las melodías de secuencia la encontramos únicamente en la tradición Oeste ${ }^{69}$. Al mismo tiempo, sin embargo, como un aspecto común a la inmensa mayoría del repertorio temprano, esta melodía fue también copiada e interpretada en conexión a diversos textos de secuencia.Y precisamente uno

${ }^{68}$ Esta fórmula, denominada "cadencia galicana", es extremadamente extraña en las melodías gregorianas tradicionales, porque, como veremos, implica una fuerte acentuación proparoxítona, y es sabido que, en el canto gregoriano, la sílaba tónica es preferiblemente cantada sobre alguna nota más aguda que las de las sílabas átonas.

${ }^{69}$ D. Hiley: Western Plainchant..., pp. 187-188; Lori Kruckenberg: The Sequence from 1050-1150: Study of a Genre in Change, tesis doctoral, University of Iowa, 1997, pp. 104-111; -: "Neumatizing the Sequence...", pp. 243-317. 
de estos textos, Congaudent angelorum, fue escrito por Notker.Aquí presentamos una transcripción del único ejemplo de esta secuencia conservado en fuentes peninsulares, concretamente en el manuscrito de San Juan de la Peña:
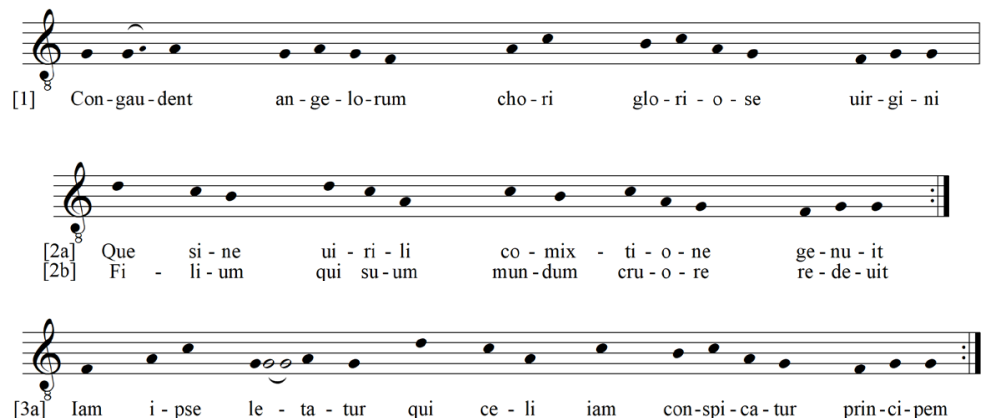

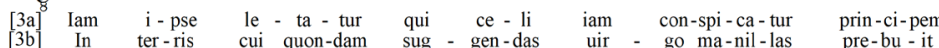
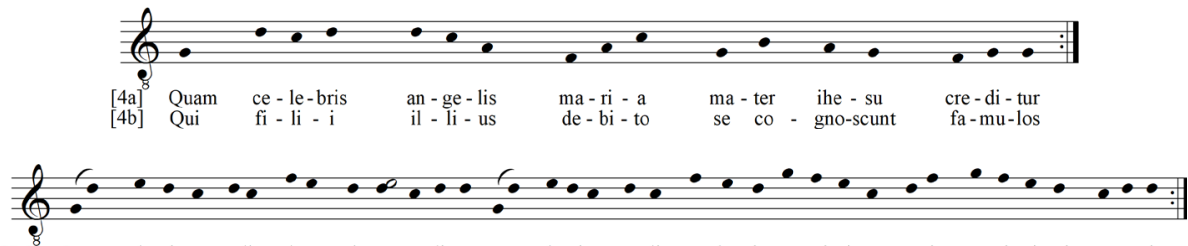

[5a] Qua glo-ri-a celis i-sta uir-go co-li-tur que domino ce-li pre-bu-it o-spi-ci-um su-i sanctis-si-mi corpo-ris

[5b] Quam splendi-da polo stella ma-ris ru-ti-lat que omnium lumen a-strorum et ho-minum atque spi-ri-lu-um ge-nu-it
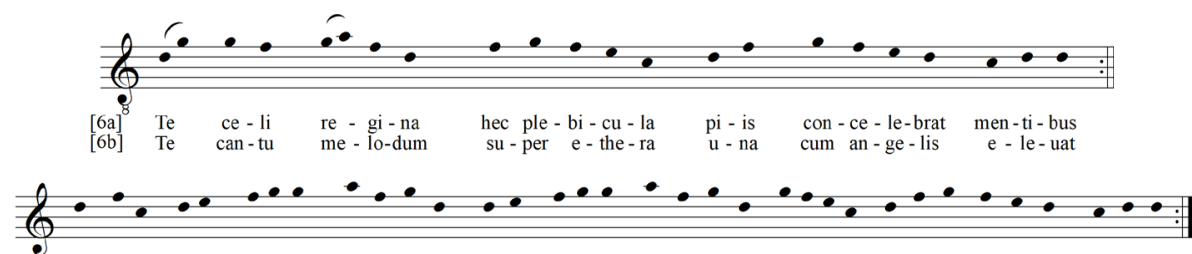

[7a] Te li-bri uirgo concinunt prophe-ta-rum chorus iu-bi-lat sa-cer-do-tum a-posto-li ce-tus-que mar-ti-num pre-di-cat pe plebis sexus sequitur u-tri-us-que ui-tam di-ligens uir-gi-na-lem ce-li-colas in ca-sti-mo-ni-a e-mulans
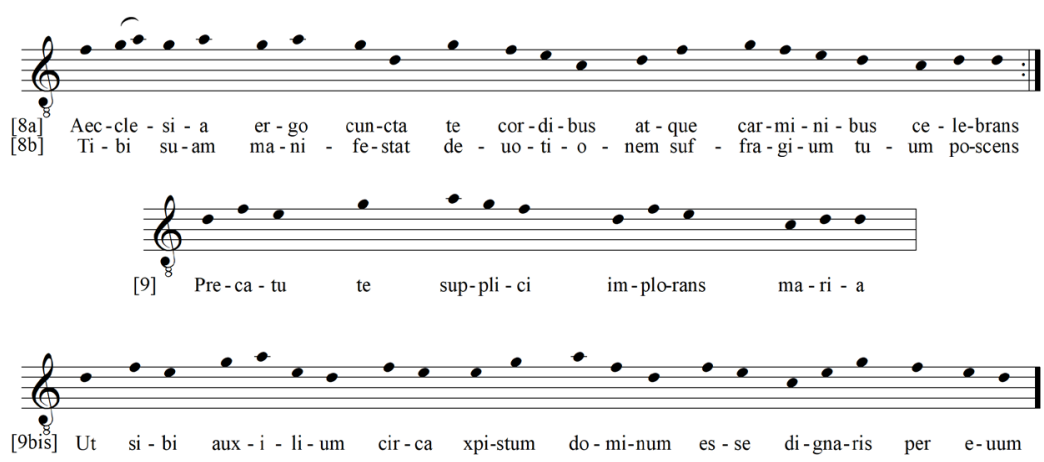

Ejemplo 2. Prosa Congaudent angelorum, en Huesca, Bibl. Capitular, Cod. 4,ff. 91v-93r (s. XII in) 
En efecto, aquí se cumple ese principio con el que el maestro Iso aconsejó a Notker, es decir, que "los movimientos individuales de la melodía deben recibir sílabas individuales". La razón, no es otra más que el hecho de que el texto esté directa e innegablemente determinado por la forma de la melodía (ejemplo 1$)^{70}$. De manera que el número de frases melódicas determina, vez tras vez, el número de líneas de texto y el número de notas, así como el número de sílabas de cada frase. También las cadencias melódicas determinan los finales de cada línea textual, ya que Notker consistentemente sitúa en estos lugares palabras con acento proparoxítono, sin emplear para ello la asonancia o algún tipo de rima, a diferencia de lo que ocurre en otras secuencias tempranas, especialmente de origen occidental, en las que es frecuente la vocalización en la letra 'a' como evocación de "alleluia".

La repetición de frases en la melodía crea, pues, pares de líneas paralelas en el texto y, en ello, la disposición de cada línea del pareado tiende a ser congruente, quizá porque Notker percibió la melodía como estructurada en pequeñas unidades y, por consiguiente, intentó adaptar las palabras a cada célula melódica. Además, las palabras que en un pareado son asignadas a una misma célula melódica tienden a tener el mismo patrón acentual, a pesar de tratarse indudablemente de $p r o s a^{71}$.

De igual manera, la estructura general de la melodía ha sido plasmada en el nivel del contenido textual, por lo que podemos decir que la disposición de los contenidos se corresponde, casi dramatúrgicamente, con el despliegue de la melodía en lo que al ambitus se refiere. Solo haría falta citar como ejemplo el hecho de que la primera alusión directa a la regina caeli (esta secuencia es para la fiesta de la Asunción de la Virgen) está emplazada en la frase 6, justo en el punto donde por vez primera se alcanza el clímax melódico.

Resumiendo, y esto vale para todo el repertorio temprano de secuencias paralelas, tenemos que el texto está determinado por la melodía, esto es, que la forma textual se comporta, por así decir, de manera "melógena" 72 , como en las prosulae. En esta dinámica, el principio de composición textual pasa a través de palabras simples o de pequeños grupos de palabras, no de frases enteras (de forma que encajen dentro del plan melódico), y los parámetros definidores

${ }^{70}$ Sorprendentemente con pequeñas e insignificantes variantes debidas lógicamente a la circunstancia de que, siendo una melodía del siglo IX, haya cruzado el reino franco (en el transcurso de más de dos siglos) para llegar a San Juan de la Peña.

${ }^{71}$ Sin embargo, esto no se cumple en todos los casos. Así tenemos: 4a ángelis María, 4b íllius débitos, donde también podría pronunciarse Mária e illius; 5 a praébuit, 5 b astrórum, que poéticamente podría articularse ástrorúm; etc. Queremos agradecer la apasionante y sugerente discusión sobre estos y otros aspectos a la Dra. Eva Castro Caridad, de la Universidade de Santiago de Compostela.

${ }^{72}$ El término melógeno, que indica que la creación de la melodía precedió al texto, junto a logógeno (donde el texto y la música son de nueva factura) y meloforme (para indicar una melodía sin texto) fue propuesto por I. Milveden y usado en las ediciones de Corpus Troporum: vol. 1, p. 15 y vol. 2, pp. 7-8. Hoy día, son comúnmente aceptados por la crítica. 
de este principio son, por un lado, su longitud, es decir, el número de sílabas y, por otro, con frecuencia, la posición del acento, sin que en ninguno de los dos casos se den patrones regulares como en el versus. Los cimientos de la construcción compositiva, pues, no se asientan en el verso poético, sino en los principios de la "Kunstprosa" o prosa poética ${ }^{73}$.

\section{La secuencia aparalela}

Llamada así por la crítica porque se trata de una morfología de secuencia que, a diferencia de la anterior, como es lógico, no depende de una estructura a base de paralelismo melódico.Y, además, suele ser mucho más breve. Su estilo melódico, pues, es diferente, ya que tiene muchas más notas repetidas que la secuencia paralela. Asimismo, tampoco los finales de los versículos suelen estar marcados por patrones cadenciales. A estas secuencias se las podría considerar como "amorfas" "74, pero hay que entender su valor artístico y su razón de ser; a lo que debemos añadir que este tipo de secuencia es el que muestra con mayor frecuencia una relación inequívoca con algún Alleluia específico de la misa.

Históricamente, las secuencias aparalelas coexistieron con las paralelas en las fuentes más tempranas y, en este sentido, es probable que fueran seleccionadas sin ninguna distinción por parte de los cantores. Algunos estudiosos han visto en ellas el paso preliminar para el desarrollo del modelo de la secuencia paralela, suponiendo que esta última fuese producto de la repetición de los versículos simples de aquéllas. Esta teoría no ha sido todavía demostrada, ni existe una clara evidencia de que la secuencia aparalela preceda a la paralela, mucho menos en términos evolutivos ${ }^{75}$.

También se ha visto en esta clase de secuencia una suerte de intersticio entre el Allelluia de la misa y la secuencia paralela. Precisamente en el estudio sobre esta tipología realizado por Kohrs ${ }^{76}$, se señala que no parece que la secuencia paralela tuviera su origen en la aparalela, pero sí es posible que el conocimiento del tipo paralelo estimulara la textualización de las sequentiae en tanto que reemplazamientos del iubilus.

Dicha acepción de ser, quizá, el tipo de secuencia más claramente emparentado con el Alleluia de la misa explica que Crocker haya intentado esclarecer, a partir de esta tipología, por ejemplo, el cómo pudieran ser las secuencias a las que Amalario se refería en el Liber Officialis (véase arriba): "Estas pequeñas

\footnotetext{
${ }^{73}$ Eduard Norden: Die antike Kunstprosa vom VI Jahrhundert v. Chr. bis in die Zeit der Renaissance, Leipzig, Teubner, 1898; Karl Polheim: Die lateinische Reimprosa, Berlín, Weidmann, 1925.

${ }^{74}$ R. L. Crocker: "Sequence", p. 99.

${ }^{75}$ L. Kruckenberg: The Sequence from 1050-1150 ..., pp. 81-83.

${ }^{76}$ Klaus Heinrich Kohrs: Die aparallelen Sequenzen. Repertoire, liturgische Ordnung, musikalischer Stil, Munich / Salzburg, Emil Katzbichler, 1978.
} 
secuencias son las candidatas más probables para las antiguas sequentiae a las que se refiere Amalario de Metz con el texto de abajo; pero no hay manera fácil de demostrar que cualquiera de estas secuencias se remonte a antes de Notker" 77 .

Más claro y taxativo sobre el lugar que ocupa esta morfología de secuencia con respecto al Alleluia y a la secuencia en general, se muestra, por ejemplo, Bower, cuando dice:

En este punto, debo mostrar una cierta incomodidad con la clasificación de "aparalela" como una especie de secuencia, particularmente cuando tal clasificación es descrita, además, como un "reemplazamiento del iubilus". "Aparalela", como es obvio, no era un criterio para clasificar melodías entre los cantores que reunían los secuenciarios tempranos del Este y el Oeste franco, ya que las melodías hoy llamadas "aparalelas" o "asimétricas" se encuentran indistintamente junto a las melodías "paralelas" y "simétricas" [...] Me parece que los elementos "asimétricos" en las secuencias representan un todo estilístico en vez de ser un subconjunto claramente definido: suele ser dificil establecer una frontera para este elemento estilístico que definiría una especie dentro del género ${ }^{78}$.

\section{La secuencia parcialmente textuada}

La ilustración $1^{79}$ representa un tercer tipo de secuencia caracterizado por el hecho de tener sus melodías únicamente texto en algunas de sus frases o en parte de ellas. Con frecuencia, estas secuencias suelen aparecer en los sequentiaria (que habitualmente recogen melodías sin texto), mientras que, por su lado, tampoco es extraño que el texto aparezca integrado en los prosaria, como parte de una prosa completa.

Stäblein ha identificado nueve de estas secuencias ${ }^{80}$, señalando que los textos parciales suelen aparecer en las frases cinco, ocho o nueve y, en algunas piezas más largas, también en las frases once o trece. Por otro lado, estos casos

${ }^{77}$ R. Crocker: "Some Ninth-Century Sequences", p. 370: "These small sequences are the most likely candidates for the old sequentiae that Amalarius of Metz refers to, with an underlaid text; but there is no easy way of demostrating that any of these particular sequences go back before Notker".

${ }^{78}$ C. M. Bower: "From Alleluia to Sequence...", pp. 365-366: "At this point I must express a certain discomfort with the classification 'aparallel' as a species of Sequence, particularly when that classification is further described as 'jubilus-replacement'. 'Aparallel' was obviously not a criterion for classifying melodies among the cantors who assembled the early East and West Frankish sequentiaries, for melodies now called 'aparallel' or 'asymmetrical' are found side by side 'parallel' and 'symmetrical' melodies [...] It seems to me that 'asymmetrical' elements in Sequences represent a stylistic continuum rather than a clearly defined subset, and it is often difficult to establish a boundary for this stylistic element that would define a species within the genre".

${ }^{79}$ Alleluia. Ecce puerpera en el manuscrito vicense de Vic, Bibl. Mus. Episc., ms. 106, f. 44v (s. XIlex / XIIIin). Arturo Tello Ruiz-Pérez: "Rethinking Partially-texted Sequence. Ecce puerpera genuit, between Italy and Catalonia", comunicación no publicada en el Seventeenth Meeting of the IMS Study Group "Cantus Planus", Venecia, 28 de julio al 1 de agosto de 2014.

${ }^{80}$ B. Stäblein: "Zur Frühgeschichte der Sequenz", pp. 1-33. 
de textualizaciones parciales parecen limitarse geográficamente a las fuentes de la tradición occidental y, más concretamente, a las regiones de Francia, del norte de España e Inglaterra.

En ocasiones, los textos de estas secuencias poseen una estructura asemejada a la del verso poético, con asonancia en "a" y, frecuentemente, de naturaleza y contenido aclamatorio. En lo que a la melodía se refiere, poseen la forma estándar o más extendida, consistente en la sucesión de pareados.

Como constata Crocker, este tipo particular ha llevado a los estudiosos a plantear varias hipótesis. Por ejemplo, con un declarado sentido evolutivo, Stäblein, siguiendo en parte a von den Steinen ${ }^{81}$, sugiere que estos textos podrían ser una primera etapa en la composición de la secuencia; un material arcaico, común, latente, del que se habría nutrido la secuencia para su constitución "normalizada" posterior. Queda velado en la hipótesis, además de un abanico multicolor ("bunt bemalt") de opciones de ejecución para el repertorio a partir de esta especie de humus primario, un posible punto de origen sobre la secuencia misma como género:

Las partes parcialmene textuadas estaban allí de antemano. Eran fórmulas sólidas, familiares para la gente de la época, que, si no estaban en boca de todos, sí al menos lo estaban en muchos oídos y corazones [...] Deben haber sido estructuras de palabras y tonadas que nadie querría perderse, tal vez reliquias galicanas, canciones populares, canciones escolares o de juglares, tal vez incluso algo así como secuencias en miniatura de un estilo muy arcaico $^{82}$.

Por su parte, Husmann ${ }^{83}$ ya antes habría apuntado una segunda hipótesis contrapuesta: la de que los textos parciales podrían actuar como interpolaciones posteriores o "tropos" en prosas ya existentes. Es decir, el curioso fenómeno de lo que sería "tropar una prosa" que -si, como hemos visto, se parte del débil presupuesto de la secuencia como un tipo de tropo-, para algunos, habría devenido en "tropar un tropo"... No obstante, rebate Crocker a ambos:

Ninguna de las hipótesis tiene suficientemente en cuenta los procedimientos estructurales comunes en el repertorio temprano en su conjunto. La localización de estos versos aclamatorios en el plan global de una secuencia ejerce una función muy específica -la de acentuar y resaltar la forma configurada de la disposición rítmica y melódica de las frases. En este sentido, los versos aclamatorios no son un fenómeno aislado, sino bastante análogos a otras características tales

${ }^{81}$ Wolfram von den Steinen: "Die Anfange der Sequenzendichtung", Zeitschrift fir Schweizerische Kirchengeschichte, 40-41, 1946-1947, p. 208.

82 B. Stäblein: "Zur Frühgeschichte der Sequenz", pp. 29-30: "Die teiltextierten Partien waren vorher da. Es waren feste, den damaligen Menschen geläufige Bildungen, die wenn nicht in aller Mund, so doch in vieler Ohr und Herz waren [...] Es müssen Wort-Tongebilde gewesen sein, die man nicht missen mochte, vielleicht gallikanische Relikte, Volksgesange, Spielmanns- oder Schola-Liedchen, vielleicht sogar so etwas wie Miniatursequenzen einer sehr archaischen Stilschich".

${ }^{83}$ Heinrich Husmann: "Sequenz und Prosa", Annales Musicologiques, 2, 1954, pp. 71-91. 
como las conclusiones de frase sobre notas no constitutivas del modo, o las frases más largas que contienen pequeñas subfrases líricas separadas con cadencias internas. En otras palabras, los versos aclamatorios necesitan ser explicados como una elección de los compositores dentro de las secuencias particulares en las que aparecen, y no como parte de un simple principio morfológico que permanece inmutable a todos los $\operatorname{casos}^{84}$.

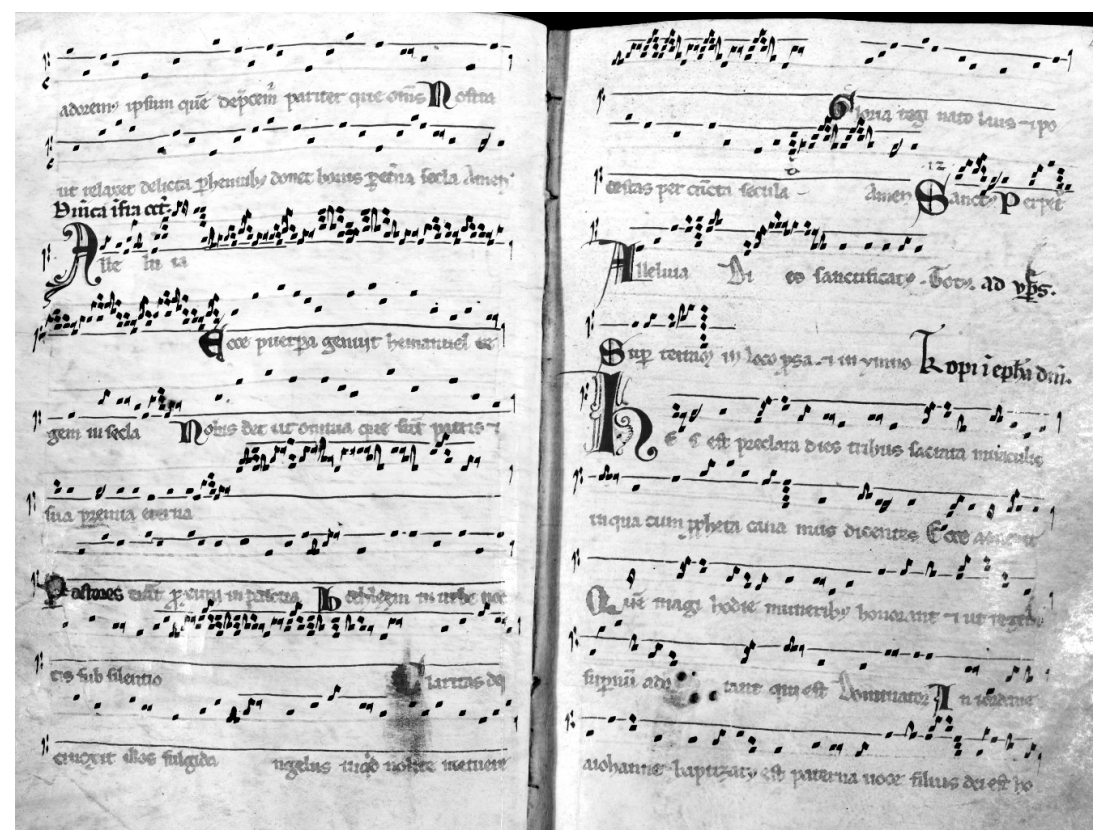

Ilustración 1. Alleluia. Ecce puerpera, en Vic, Bibl. Mus. Episc., ms. 106, ff. 44v-45r (s. XII ex / XIII in). Biblioteca Museo Episcopal de Vic

\section{Las grandes tradiciones: Este, Oeste e italiana}

El plan de unificación cultural y litúrgica trazado en primera instancia por Pipino y, más tarde, por Carlomagno fue realizado en una época en la que, como dice Huglo,

${ }^{84}$ R. L. Crocker: "Sequence", p. 100: "Neither hypothesis takes sufficient account of the structural procedures common in the early repertory as a whole. The location of these acclamatory verses in the overall plan of a sequence performs a very specific function -that of accenting and highlighting the shape brought about by the melodic and rhythmic disposition of phrases. In this respect, the acclamatory verses are not isolated phenomena, but quite analogous to other features, such as phrase-endings on non-final pitches, or the longer phrases that contain short lyrical subphrases marked off with internal cadences. In other words, the acclamatory verses need to be explained as composer's choices within the individual sequences in which occur, not as part of a single morphological principle that holds for all instances". 
El latín ya no era el vehículo de intercambio en la vida económica, en la sociedad, ni en la familia. En cierto modo, la reforma carolingia se asentó sobre dos bloques lingüísticos: el bloque de los dialectos tudescos, por una parte, y el bloque de la Romania, es decir, el conjunto de países en los que se habla una lengua nacida del latín ${ }^{85}$.

Después del año 814, fecha de la muerte de Carlomagno, las luchas políticas y la división del Imperio no hicieron más que reducir las comunicaciones entre estos dos bloques lingüísticos y contribuir a su aislamiento. La consecuencia litúrgica no tardó en hacerse patente: todas las piezas creadas en el transcurso de los siglos IX hasta mediados del XI entre las que se cuenta todo el corpus de secuencias tempranas-, ya sea en el Este o en el Oeste, raramente conocieron una difusión internacional demasiado amplia.

Fruto de este aislamiento es posible hablar de unas claras diferencias en el desarrollo de la secuencia como género en diferentes lugares. No obstante, estas divergencias han sido con frecuencia minimizadas e, incluso, ignoradas por los estudios musicológicos, mientras que las similitudes han sido fuertemente enfatizadas. Si bien es cierto que se ha hablado y reconocido una serie de variantes a nivel textual, la tendencia generalizada ha consistido en considerar todas las secuencias como constituyentes de un único género, como producto de un "genio franco" colectivo ${ }^{86}$. En este sentido, algunos investigadores como Karlheinz Schlager ${ }^{87}$, Haug $^{88}$ y, más recientemente, Lori Kruckenberg ${ }^{89}$, suponen una excepción en lo que se refiere a la conciencia de separación cultural que supuso esa barrera.

Así, por ejemplo, Schlager señala que las diferentes maneras de escribir los repertorios en ambas tradiciones tienen más importancia de la que tradicionalmente se le ha dado y que, en suma, estas diferencias deberían ser entendidas como un reflejo de las distintas maneras de concebir el género. Pero, quizá,

\footnotetext{
${ }^{85}$ Michel Huglo: "La division de la tradition monodique en deux groupes 'est' et 'ouest", Revue de Musicologie, 85, 1999, p. 5: "Le latin n'était plus le véhicule des échanges dans la vie économique, dans la société et dans la famille. La réforme carolingienne a été en quelque sorte plaquée sur deux bolcs linguistiques: le bloc des dialectes tudesques d'une part, et le bloc de la Romania, c'est-à-dire l'ensemble des pays où l'on parle une langue issue du latin".

${ }^{86}$ Crocker frecuentemente emplea esta expresión en The Early Medieval Sequence.

${ }^{87}$ Karlheinz Schlager: "Beobachtungen zur frühen Sequenz in ost- und westfränkischer Überlieferung", Gordon Athol Anderson (1929-1981). In memoriam, Luther Dittmer (ed.), Henryville, The American Institute of Musicology, 1984, vol. 2, pp. 531-543.

${ }^{88}$ Andreas Haug: Gesungene und schriftlich dargestellte Sequenz. Beobachtungen zum Schriftbild der ältesten ostfränkischen Sequenzenhandschriften, Neuhausen / Stuttgart, Hänssler-Verlag, 1987, pp. 7-14.

${ }^{89}$ Lori Kruckenberg: "The Absence of Transmission. Symptoms of a Musical-Cultural Reception Barrier between the West- and East Frankish Regions", Musik und kulturelle Identität: Bericht über den XIII. Internationaler Kongress der Gesellschaft für Musikforschung in Weimar 2004, Detlef Altenburg, Rainer Bayreuther (eds.), Kassel, Bärenreiter, 2012, vol. 2, pp. 466-76.
} 
podríamos extender el valor de estas divergencias a un ámbito más extenso, tocando puntos como aquel que atañe al intento de comprender plenamente el empleo de la palabra sequentia en el contexto de la terminología medieval.

De esta manera, tenemos que, en la tradición Este, el término sequentia definía la unión de la música y del texto, por lo que, y de manera general, el término prosa no se utilizó para referirse al género secuencia. Esto quizá se debió a que las melodías de secuencia no se encontraban escritas (a excepción de algunas fuentes como Sankt Gallen, Stiftsbibliothek, Codex 484) en un lugar aparte al de los textos, es decir, que no se encontraban recopiladas en fuentes o elencos propios como veremos sucedía en el Oeste.

La distribución tipo de cada página en las fuentes orientales de los siglos X y XI fue la siguiente (véase ilustración 2): los textos eran copiados en la parte interior del folio, mientras que a su lado, en el margen exterior, se colocaban los neumas. Cada frase o versículo empezaba en una nueva línea, con una mayúscula en color, y los primeros neumas de cada melodía estaban normalmente escritos sobre las palabras "alleluia", “aeuia" o "aeua". Normalmente el nombre de la melodía solía acompañar a cada secuencia, bien al inicio de la notación, bien junto a la rúbrica de la fiesta o, inclusive, al lado de la rúbrica sequentia. Solo en algunas contadas excepciones en las colecciones del siglo X, se hizo uso de la notación interlineal que empezó a predominar a partir del año $1100^{90}$.

Por su parte, en el Oeste existieron fundamentalmente dos maneras de escribir las secuencias: sin texto y con texto. Por un lado, las no textuadas fueron secuencias escritas como un melisma nuevamente bajo la palabra "alelluia" ('aeuia' o 'aeua'), en las que en algunos casos se situaba una 'a' insertada en el inicio de cada frase musical (el equivalente a un versículo en la versión textuada) e, incluso, se utilizaban letras para marcar los finales de las líneas musicales (véase ilustración 3). Era común que estas secuencias melódicas fueran recopiladas juntas en fascículos independientes de los libros litúrgicos (sequentiaria), normalmente bajo la indicación incipiunt sequentiae.

Por otro lado, las denominadas prosae (secuencias con texto) podían aparecer también juntas en elencos aislados (prosaria), frecuentemente con el título incipiunt prosae $e^{91}$. En cuanto a su escritura, la neumatización solía estar dispues-

${ }^{90}$ Para un listado completo de las fuentes del Este y del Oeste hasta el siglo XII, véase las tablas en L. Kruckenberg: The Sequence from 1050-1150..., pp. 115, 118, 121. Para el Este, véase también Susan Rankin: "The Earliest Sources of Notker's Sequences in St Gallen, Vadiana 317 and Paris, Bibliothèque Nationale lat. 10587", Early Music History, 10, 1991, pp. 201-233.

${ }^{91}$ Como ya hemos visto, en la Edad Media, existieron otros significados para estos términos, ya que, por ejemplo, también se denominaba como sequentia a las prolongaciones melismáticas del Alleluia y como prosa a determinadas formas trópicas (llamadas también prosulae, como diminutivo de prosa) consistentes en la adaptación de textos de nueva composición a los melismas de determinados cantos oficiales. 
ta interlinealmente, como sucede en otros cantos, mientras que la presentación de los textos, contrariamente a lo que sucedía en el Este, no reflejaba una estructura de versículos sino más bien de "prosa", es decir, a renglón corrido.

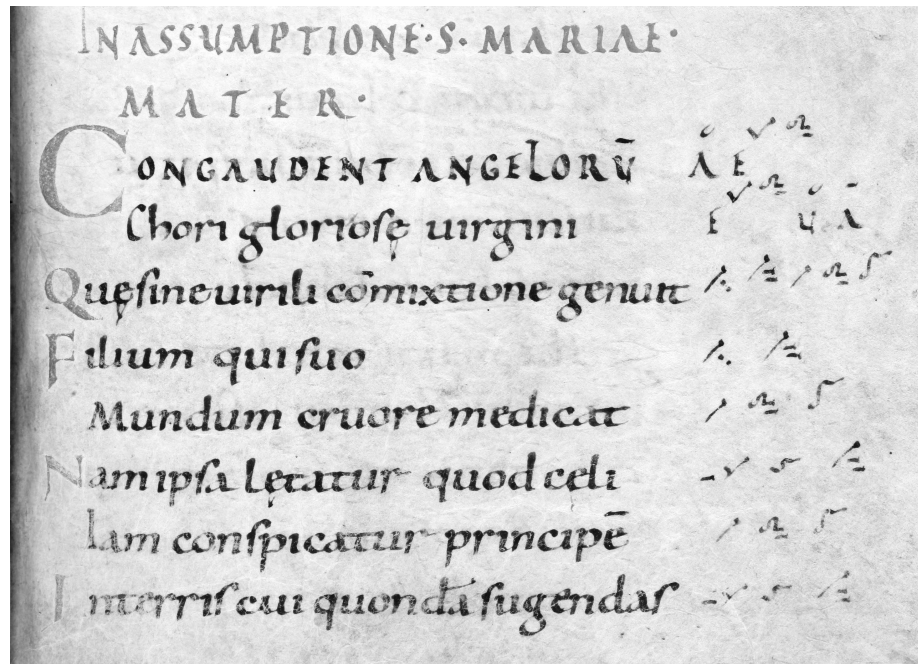

Ilustración 2. Congaudent angelorum (melodía Mater), en Sankt Gallen, Stiftsbibl. Cod. 381, p. 443. Sankt Gallen, Stiftsbibliothek, www.e-codices.ch

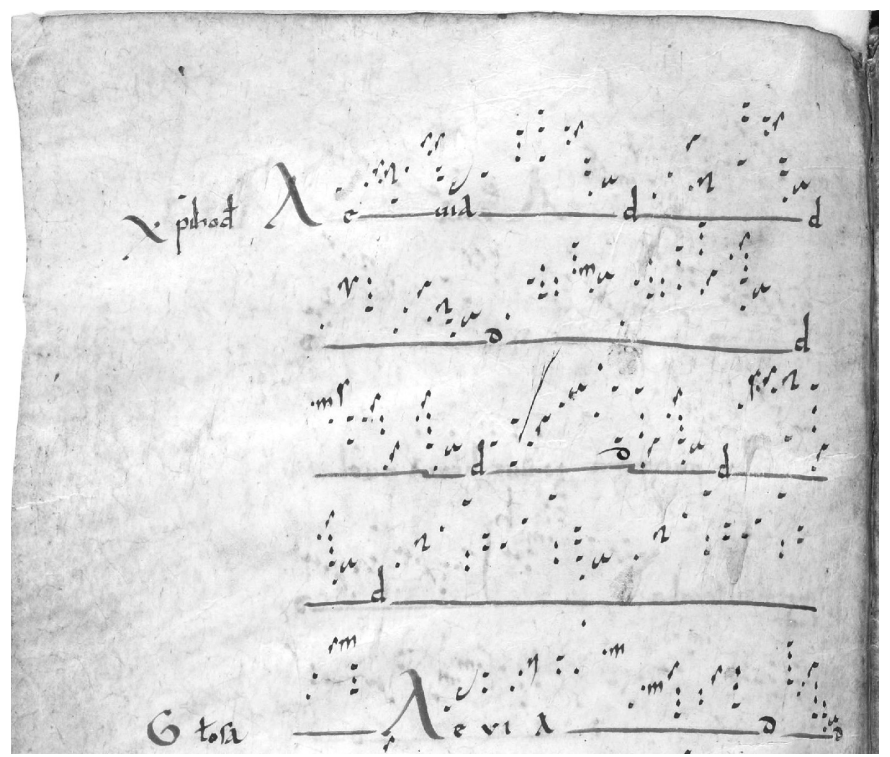

Ilustración 3. Melodía Christi hodierna (=Mater, en la tradición Este), en París, Bibl. Nat., lat. 1084, f. 199, gallica.bnf.fr / BnF 
Kruckenberg ${ }^{92}$ da al menos cuatro excepciones a esta manera de separar secuencias y prosas. En primer lugar, cita el gradual de Nevers de mediados del siglo XI (París, Bibliothèque Nationale, lat. 9449), una fuente que combina la forma textual con la no textual, esto es, alternando los versos con texto y música con las melodías sin texto. Los otros tres ejemplos de ello pertenecen a fuentes italianas:Apt,Archives de la Basilique Sainte-Anne, ms. 18 (s. X ex / XI in); Verona, Biblioteca Capitolare, CVII (s. XI in), y Turín, Biblioteca Nazionale, naz. G.V.20 (s. XI in). Es muy posible que esta manera de escribir las secuencias tuviera mucho que ver con su interpretación, es decir, que pareciera haber estado reservado al juicio de los intérpretes el decidir la alternancia de lo textual con lo meramente musical a la hora de cantar.

Precisamente estas diferentes maneras de escribir las melodías y los textos de las secuencias han sido fuente de discusión en el seno de la crítica musicológica. Una primera posición, representada principalmente por Crocker, plantea que la secuencia puramente melismática no sería más que una manera de mostrar una mayor información musical en aquellos casos en los que la notación de la prosa pudiera entrañar algún grado de ambigüiedad.Y en este sentido, añade que la primera forma del género habría sido la textual y que, por tanto, las secuencias siempre habrían sido cantadas en su forma "completa", esto es, texto y música ${ }^{93}$.

Ciertamente, la hipótesis planteada por Crocker se vería cumplida en lo que concierne a las secuencias del Este, y en algunos casos en los que su notación adiastemática sí necesitaría ser aclarada, pero en el caso de las fuentes occidentales, cuya notación es bastante diastemática a partir del siglo XI, no existe diferencia de precisión y claridad en la manera de copiar los prosaria y sequentiaria, pues en ambos tipos de colecciones se proporcionaba la misma información en lo que a la melodía se refiere.

Por consiguiente, una segunda gran hipótesis ha sido planteada: que ambas versiones, tanto las que llevan texto como las exclusivamente melódicas, fueran susceptibles de ser interpretadas. De modo que algunos estudiosos, como Husmann ${ }^{94}$, han señalado la posibilidad de que la ejecución consistiera en la sucesión de una frase cantada silábicamente y, a continuación, otra melismáticamente. Por su parte, Smits van Waesberghe ${ }^{95}$ ha apuntado que la interpretación podría hacerse de manera melismática (por el o los solistas) y silábica (por la schola cantorum) de forma simultánea. Como señalábamos antes, Hiley, más recientemente, tras varios estudios en los que

92 L. Kruckenberg: The Sequence from 1050-1150..., pp. 103-104.

${ }^{93}$ R. L. Crocker: "Sequence", p. 149.

${ }^{94}$ H. Husmann: "Sequenz und Prosa", pp. 61-91.

${ }^{95}$ Joseph Smits van Waesberghe: "Einleitung zu einer Kausalitätserklärung der Evolution der Kirchenmusik im Mittelalter (von etwa 800 bis 1400)", Archiv für Musikwissenschaft, 26, 1969, pp. 249-275. 
trataba de clarificar el papel de las secuencias y los tropos en Cluny, ha afirmado que las secuencias, aun teniendo texto, pudieron ser interpretadas también de forma puramente melódica ${ }^{96}$.

A medio camino entre las tradiciones Este y Oeste, pero con las suficientes características propias como para considerarla una tradición aparte, está la península itálica. Los orígenes de la secuencia en Italia son obscuros, ya que prácticamente no se conservan fuentes anteriores al año 1000.Además, en las fuentes tempranas es poco habitual encontrar las secuencias ordenadas en fascículos ad hoc; normalmente están intercaladas a lo largo del año litúrgico, en su lugar correspondiente de la misa.

En cuanto a la terminología, tanto sequentia como prosa se utilizaron indistintamente para identificar las secuencias con texto, puesto que las secuencias melódicas o con texto parcial fueron casos muy excepcionales en Italia. Esta ambivalencia en cuanto a la terminología vino a reflejar el sincretismo característico del repertorio italiano en lo que respecta a su formación: coexistieron secuencias del Este, del Oeste y algunas de producción local.

Sin embargo, apenas existen secuencias conocidas internacionalmente, aunque muchas fueran conocidas en el Este e Italia, o en el Oeste y en Italia. Además, como apunta Kruckenberg ${ }^{97}$, en las fuentes italianas existió una clara separación de las secuencias de las dos tradiciones, Este y Oeste, al menos hasta el siglo XI. Para Kruckenberg esto es un signo más que confirma que existió una barrera en la recepción, intencionada o, al menos, consciente ("Rezeptionsbarriere"), entre el repertorio de secuencias de las tradiciones del Este y del Oeste del Imperio Franco.

Como señala Hiley ${ }^{98}$, formalmente las secuencias de origen italiano no presentaban la regularidad de estructura que existía en las otras dos tradiciones, además de que algunas versiones italianas de secuencias del norte mostraron bastantes irregularidades. Otra peculiaridad en su estructura fue la aparición frecuente de frases simples, en contraste con los habituales pareados que dominaron en las otras dos tradiciones. Tampoco mantuvieron el característico "silabismo" de las secuencias del norte, sino que, en muchos casos, para una sílaba utilizaron dos o más notas, o se repitieron las mismas hasta acomodarlas a las sílabas. A este propósito, es llamativo un pequeño grupo de secuencias que

\footnotetext{
${ }^{96}$ David Hiley: "Cluny, Sequences and Tropes", La Tradizione dei Tropi Liturgici, Claudio Leonardi, Enrico Menestrò (eds.), Spoleto, Centro italiano di studi sull'alto medioevo, 1990, pp. 125-138; —: "The Sequentiary of Chartres Bibliothèque Municipale, Ms. 47", La Sequenza Medievale. Atti del Convegno Internazionale, Milano, 7-8 aprile 1984, Agostino Ziino (ed.), Lucca, Libreria Musicale Italiana, 1992, pp. 105-117; —: "The Sequence Melodies...", pp. 131-155; —: "The Repertory of Sequences...", pp. 153-193.

${ }^{97}$ L. Kruckenberg: The Sequence from 1050-1150.., p. 125.

${ }^{98}$ D. Hiley: Western Plainchant..., p. 183.
} 
hicieron uso de la técnica de la variación, en base a que su estructura consistió en una melodía que iba sufriendo transformaciones a lo largo de todos los versos de la composición.

Aunque la producción italiana fue menor con respecto a las otras regiones, sí parece ser que existieron varias iglesias y monasterios muy activos en la composición de secuencias $^{99}$. Además, como señala Hiley, es bastante probable que las discrepancias y diferencias que encontramos entre las maneras de componer de las regiones del norte y las de Italia, se deban a que los músicos italianos asimilaron la secuencia como un género externo, ajeno y que, por ello, muchas veces volvieran a sus propios hábitos compositivos "pre-gregorianos"; en ocasiones, poco o nada parecidos con la secuencia nacida en el seno del Imperio.

En resumen, se puede decir que los inicios de la secuencia están marcados por la diversidad. Efectivamente, una diversidad de tradiciones, de recopilaciones, de estructuras... que, como veremos más adelante, confluiría a partir de los siglos XI y XII en un tipo más uniforme e internacional (superándose esa barrera Este-Oeste), en el que la secuencia como género estaría mucho más normalizadamente definida y adoptaría una forma mucho más estable.

Por tanto, en el tránsito de los siglos IX al XI, los artistas medievales crearon una gran variedad de repertorios y diversidad de cantos; nuevas categorías de canción litúrgica para decorar más solemnemente la misa: los tropos (para el ordinario y el propio), las prosulae (sobre todo para el Gloria, el Alleluia, el Ofertorio y el Osanna del Sanctus) y las secuencias, tanto textuadas como no textuadas. A partir de mediados del siglo XI, sin embargo, la situación de este corpus de nuevas piezas cambiaría sustancialmente. Sin ir más lejos, mucho de este repertorio, en el s. XIII, habría desaparecido en favor de otros repertorios más grandes y, a la postre, más extendidos internacionalmente.Todo ello, empero, no impidió que algunas secuencias tempranas convivieran entremezcladas con estos nuevos repertorios, sobreviviendo, por ejemplo, junto a algunos elencos de los tropos del ordinario, gracias al peso de la tradición, a los movimientos reformadores de los siglos XII y XIII y a una especie de fascinación emanada del propio género secuencia.

\section{El estilo de la secuencia de transición}

La secuencia hay que entenderla como un género que está en continuo cambio, en continua transformación. Por ello, el paso de lo que llamamos primer estilo (desde aproximadamente los inicios siglo IX hasta principios del XI)

\footnotetext{
${ }^{99}$ Para un catálogo de las fuentes con secuencias italianas, véase Lance W. Brunner: "Catalogo delle sequence in manoscritti di origine italiana anteriori al 1200", Rivista Italiana de Musicología, 20, 1985, pp. 191-276; - : The Sequences of Verona, Biblioteca Capitolare XVII and the Italian Sequence Tradition, tesis doctoral, University of North Carolina at Chapell Hill, 1977. Por supuesto, de suma utilidad es Giacomo Baroffio (ed.): Iter Liturgicum Italicum, Padua, CLEUP, 1999.
} 
y el segundo (a partir de mediados del XII), lleva implícito un proceso de transición que se encuentra a caballo entre ambos. Pero como proceso de transición que es, merece un estudio detallado, al igual que los otros dos estilos, el "temprano" y el "clásico" o rimado, de manera que nos permita conocer más y mejor cómo ha variado la secuencia ${ }^{100}$.

Ya cuando editaron los volúmenes de Analecta Hymnica $(A H)$, Clemens Blume y Henry Marriott Bannister decidieron organizar las secuencias según un criterio cronológico determinado por criterios estilísticos, aplicando las etiquetas de primera época y segunda época. Pero, entonces, cayeron en la cuenta de que había noventa y cuatro secuencias que, por sus características, no podían incluirse en las dos etapas establecidas de partida. Tal fue el modo en el que Blume y Bannister optaron por introducir, entre las dos etapas, una de transición ${ }^{101}$.

Dedicaron no pocas páginas de $A H$ a la explicación de este concepto de transición. Por ejemplo, señalaron la dificultad que entraña en casos individuales situar una secuencia en el estilo de transición o en el de la segunda época, ya que, es frecuente encontrar una rima mantenida, junto a un ritmo y simetría que distan mucho de ser plenos. $\mathrm{O}$, por el contrario, una perfecta estructura rítmica y simétrica que, sin embargo, descuida la rima. También apuntaron la dificultad en algunos casos de distinguir si una secuencia debe ir en el estilo de transición o en la primera época, ya que algunas como Laude dignum $(A H, 53,203)$, atribuida a Notker y, por lo tanto, del primer periodo, tienen un ritmo simétrico y asonancia en todos sus versos. Es harto complicado, pues, decidir dónde debe situarse una prosa con estas características $^{102}$.

Estos autores resaltaron otro problema importante que se suma al anterior. Se trata del referente al arco temporal, puesto que la transición de un periodo a otro -casi por definición- nunca tiene una delimitación exacta en el tiempo. En torno al siglo XI, existen secuencias que tienen claramente las características del estilo de transición, como la tendencia a la rima versificada. Pero también, alrededor de este tiempo, existía una predilección por las secuencias en prosa, no limitadas por el ritmo y la asonancia, que no dejaron de existir ni mucho menos. Bien al contrario, estas predominaron casi de forma exclusiva durante el siglo XI. Por otro lado, ya a finales del siglo XI, aparecieron secuencias que daban muestra de un más que perfeccionado dominio técnico del

${ }^{100}$ Aunque son numerosos los estudiosos que han hecho alusiones de manera general a este estilo de transición de la secuencia, como ahora veremos, el primer estudio en profundidad de esta fase, lo realizó como tema clave de su tesis doctoral Lori Kruckenberg, y dicho estudio supone el principal cimiento de nuestras afirmaciones en este apartado. L. Kruckenberg: The Sequence from 1050-1150..

${ }^{101}$ Clemens Blume, Henry Marriott Bannister: Thesauri hymnologici prosarium, AH, 54, 5.

102 Véase AH, 54, 5-6. 
ritmo y la rima en sus estrofas. Esto no supuso que las secuencias de "transición" tuvieran un fin próximo, sino que continuaron existiendo durante centurias hasta principios del siglo XVI.

Debido a todo ello no sería correcto hablar de secuencias del "periodo de transición", ya que esto podría interpretarse en un sentido cronológico, lo que llevó a los editores de $A H$ a concluir que la mejor manera de definirlas sería como secuencias del "estilo de transición". Así lo hacemos nosotros.

Un ejemplo representativo de lo que venimos hablando es Victimae paschali laudes ${ }^{103}$, una de las cuatro que "sobrevivieron" a Trento. En ella, el ritmo simétrico está en todas partes, pero de forma sugerente, no impositiva; solo en medio del pareado de la estrofa 4 y 5 y la parte de cierre de la 6 y 7, la rima aparece de forma plena, mientras que las tres primeras estrofas guardan una tipología estilística más cercana a la secuencia temprana, a pesar de que, a la vez, los versos están limitados por la asonancia. Victimae paschali laudes es muestra, no obstante, de un viraje claro hacia la versificación, hacia la poesía. Da síntomas de un tipo de versificación que, por lo demás, busca deliberada y palatinamente la regularización y el estrofismo.

Tras las afirmaciones de Bannister y Blume, otros estudiosos, basándose fundamentalmente en lo señalado por ellos, han aludido a estas cuestiones en estudios generales de la época medieval, en diccionarios y en libros que se refieren a la historia de la secuencia. Destacaremos solo alguno de ellos, por espacio, que puedan resultar de interés para entender mejor el estilo de transición. Así, la reflexión de John Stevens:

La historia de la secuencia $[\ldots]$ se divide frecuentemente en tres etapas: la primera $[\ldots]$ en la que los textos fueron una especie de "prosa poética", gobernada por la simetría y un patrón, pero no por una medida cuantitativa ni por un acento cualitativo; la segunda, en la que los textos se vuelven más regulares de distintos modos y se pueden llamar, sin violencia alguna, versos; y una tercera, que tiene como figura central a Adam de St.Victor, en la que las estrofas están tan estandarizadas en estructura y rima, que los poemas se parecen a los himnos -solo la progresión melódica (AA, BB, CC, etc.) las distingue como secuencias- ${ }^{104}$.

${ }^{103}$ Véase Graduale Triplex, edición crítica a cargo de los monjes de Solesmes, Solesmes, Abbaye de Saint Pierre / París, Desclée, 1979, p. 198.

${ }^{104}$ John Stevens: Words and Music in the Middle Ages. Song, Narrative, Dance and Drama, 1050-1350, Cambridge, Cambridge University Press, 1986, p. 91: "The history of the sequence [...] is often divided into three stages: the first [...] in which the texts were in a sort of "poetic prose," governed by symmetry and pattern but not by quantitative measure nor by qualitative accent; the second, in which the texts became more regular in various ways and could without violence to the term be called "verse"; and a third, having Adam of St. Victor as its central figure, in which the strophes are so standardized in structure and rhyme that the poems resemble hymns -only the melodic progression (AA BB CC etc) distinguishes them as sequences". 


\section{Otro de los textos que hacen alusión al estilo de transición es el de Paul Evans cuando afirma:}

Los textos de la secuencia temprana estaban en una especie de prosa elevada [...] En el siglo XI, un periodo de transición comienza en la historia de la secuencia. La rima empieza a reemplazar a la asonancia y una estructura estrófica más regular se da en lugar de las irregulares longitudes de las frases de las secuencias tempranas. Nuevas composiciones de melodías empiezan a suceder, y es presumiblemente esta nueva libertad melódica lo que permite la creación de formas poéticas más estructuradas. Un buen ejemplo de este tipo de secuencia de transición es "Victimae paschali" [...] Con el siglo XII, la secuencia alcanza su forma final [...] habiéndose convertido en algo muy parecido a un himno, con los versículos pareados de la forma temprana reemplazados por estrofas pareadas regulares, de versos hímnicos y rimados ${ }^{105}$.

Y, por último, aludiremos a otro estudioso, Wulf Arlt, que se ha referido a la necesidad de estudiar la secuencia denominada de "transición" en el contexto de la "neues Lied" [nueva canción] o los nova cantica:

Para el llamado periodo de "transición" de la secuencia "clásica" a la "regular" en los siglos XI y XII, la atención se ha centrado en aspectos textuales. Las cuestiones musicales, y especialmente la relación entre la música y el texto, se han descuidado hasta un grado sorprendente. Prácticamente no hay secuencia de este periodo para la cual la transmisión haya sido estudiada sistemáticamente, incluidas las fuentes con notación neumática. Los comentarios interpretativos generalmente se basan en versiones del siglo XII o incluso del XIII; y hay numerosas teorías no verificadas sobre la ornamentación de melodías concebidas silábicamente y cuestiones similares ${ }^{106}$.

${ }^{105}$ Paul Evans: "Sequence", The New Harvard Dictionary of Music, Don M. Randel (ed.), Cambridge, Massachusetts, Belknap Press of Harvard University Press, 1986, pp. 739-740: "The texts of the earliest sequences were in a kind of elevated prose $[\ldots]$ In the $11^{\text {th }}$ century, a transitional period in the history of the sequence begins. Rhyme begins to replace assonance, and a more regular strophic structure is found in place of the irregular phrase lengths of the earlier sequence. Newly composed melodies begin to occur, and it is presumably this new melodic freedom that allows for the creation of more structured poetic forms. A fine and familiar example of this type of transitional sequence is "Victimae paschali" [...] With the $12^{\text {th }}$ century, the sequence reaches its final form [...] hav[ing] become quite hymn like, with the paired versicles of the earlier form replaced by regular paired strophes of hythmic and rhymed verse".

106 Wulf Arlt: "Sequence and Neues Lied", La Sequenza Medievale. Atti Del Convegno Internazionale, Milano, 7-8 aprile 1984, Agostino Ziino (ed.), Lucca, Libreria Musicale Italiana, 1992, p. 3: "For the so called period of 'transition' from the 'classical' to the 'regular' sequence in the eleventh and twelfth centuries, attention has been concentrated on textual aspects. Musical questions, and especially the relationship between music and text, have been neglected to an astonishing degree. There is almost no sequence of this period for which the transmission has been studied sistematically, including the sources with neumatic notation. Interpretative remarks are usually based on versions of the twelfth or even the thirteenth centuries; and there are numerous unproven theories concerning ornamentation of syllabically conceived melodies, and similar questions". Justo sobre muchas de estas cuestiones a las que alude Arlt, como la transmisión o, sencillamente, para un ejemplo de análisis de algunos de los rasgos del estilo de transición y del de la secuencia del siglo XII, remitimos a nuestros sendos estudios sobre la prosa Gratulemur et laetemur. A. Tello Ruiz-Pérez: "Tras el rastro de tropos..."; A. Tello Ruiz-Pérez, P. Peláez Bilbao: "La prosa Gratulemur et laetemur...". 
Según Kruckenberg ${ }^{107}$, hay que destacar cuatro puntos que parecen ser constantes y que son objeto de debate cuando nos referimos a este estado de "transición": 1) que el siglo XI y principios del XII es esencialmente la etapa de transición en la historia de la secuencia;2) que la libertad melódica y las nuevas composiciones de melodías son rasgos sobresalientes en la secuencia del siglo XI;3) que se halla en implicación un corpus de secuencias que conforma un repertorio coherente, y 4) que existen dos secuencias que son características y representativas de todo el grupo, Victimae Paschali Laudes $(A H, 54,7)$ y Laetabundus exultet fidelis chorus $(A H, 54,2)$.

Señala Kruckenberg, por otro lado, cómo esas primeras alusiones realizadas por Blume y Bannister a las "secuencias de estilo transicional", frecuentemente se han convertido en sinónimo de secuencias del "periodo transicional" para muchos estudiosos de este género. Pero Blume y Bannister, como hemos dicho, a diferencia de otros investigadores, no pretendían encuadrar esas noventa y cuatro secuencias en criterios temporales, entre una primera y segunda época.

El trabajo de Kruckenberg se basa en parte en lo que aporta $A H$, con la diferencia de que ella ha dividido las secuencias de transición de Blume y Bannister en seis grupos, por centurias, de acuerdo con las fechas de los más antiguos testimonios conservados. En este sentido, en determinados casos ha tenido que corregir -en base a estudios posteriores- algunas de las fechas otorgadas a las fuentes. Por ejemplo, $A H$ cita para la secuencia Stola iocundatis $(A H, 54,61)$ varias fuentes del siglo XII como los más antiguos testimonios, pero omite el de Cambrai, Bibl. municipale, ms. 78, que es del siglo XI.

Este desajuste en las dataciones hechas por Blume y Bannnister tiene una clara explicación, ya que, de las noventa y cuatro secuencias, cuarenta y nueve (casi la mitad) no pueden ser datadas antes del siglo XIII. De otra parte, algunas de estas secuencias de transición son anteriores incluso al manuscrito más antiguo que las conserva, y otras no fueron compuestas hasta finales de la Edad Media. Pero lo más importante es que no debemos olvidar que tanto el estilo literario de la primera época, como el estilo de transición, se cultivaron también hasta el siglo XVI, coexistiendo con las secuencias rimadas de la segunda época.

Siempre se ha aludido a este estilo de transición en términos meramente textuales, poéticos, pero para comprender este proceso de cambio, que se estaba generando en torno a la mitad del siglo XI y principios del XII, se requiere, como ha llevado a cabo Kruckenberg, una investigación de sus

${ }^{107}$ L. Kruckenberg: The Sequence from 1050-1150 ..., p. 38. 
aspectos musicales, su diseminación por Europa, el contexto en el que se produjeron y sus fuentes. Los resultados más relevantes a los que ha llegado se resumen en que:

1. De todas esas melodías, veintisiete (por debajo de $30 \%$ ) son textos dados a melodías de la primera época, que se conocían ya aproximadamente antes del año 1000.

2. De estas veintisiete melodías anteriores al año 1000, determina que existen ocho de transición dadas a la melodía de la secuencia Ave praeclara maris stella (atribuída a Herman de Reichenau, también conocido como Hermannus Contractus, que murió en 1054). Un hecho significativo al respecto es que esta secuencia no circuló con nombre independiente como hacían las secuencias tempranas. Así, estas secuencias y las anteriormente citadas suman treinta y cinco de las noventa y cuatro, es decir, que hallamos un $37 \%$ que utilizaron melodías conocidas antes de aproximadamente el 1050.

3. Otras diez secuencias de transición están vinculadas con melodías de secuencias atribuidas a Gottschalk de Aquisgrán.

4. Por otro lado, del total de noventa y cuatro secuencias, existen treinta y dos melodías que conocemos hoy en día solo por fuentes posteriores al año 1050. De estas treinta y dos, no todas se encuentran entre los años 1050-1150, sino que nueve pueden remontarse hasta el siglo XI, y once al siglo XII. Algunas de estas nuevas melodías estuvieron ampliamente diseminadas, y algunas tenían más de un texto.

Por lo que parece, pues, se perpetuó esa tradición de la secuencia temprana correspondiente a que a una melodía se le añadieran diferentes textos. Por otro lado, existen algunas diferencias entre ambos estilos en este aspecto; por ejemplo, una tendencia mayor hacia la ornamentación en lugar de una textura silábica. En este sentido, debemos recordar que la textualización era el principal procedimiento para la creación de los textos de las nuevas secuencias durante la secuencia temprana, mientras que, en la secuencia del siglo XII, como veremos, los textos solían ser contrafacta de un texto antecedente, incluso parodias organizadas por "familias".

Dos secuencias, en efecto, se sitúan como representativas de este estilo, Victimae paschali Laudes y Laetabundus exultet, y lo hacen no solo como paradigmas convenidos por la crítica moderna, sino porque sus melodías sirvieron de molde compositivo durante, incluso, siglos sucesivos. Compuestas ambas hacia mediados del siglo XI, ya hemos dado cuenta rápida de algunas características de Victimae paschali, pero lo relevante de ellas es que, como marcas de estilo, amortizan un vertiginoso éxito de difusión de estas 
dos secuencias que, en el caso de esta de Pascua, llegó a borrar la separación entre las tradiciones del Este y del Oeste. Es en este punto donde, precisamente, hallamos una nueva clave que, en virtud del estilo, queda abierta con la secuencia de transición, a saber, la "internacionalización”, el carácter paneuropeo ${ }^{108}$.

Otro aspecto significativo es el que atañe a las fuentes y elencos en los que aparecen las secuencias de este estilo. De tales colecciones se desprende que no es posible establecer o identificar centros de producción específicos, compositores o fuentes concretas que sobresalgan, como sin embargo sí sucede para las secuencias tempranas y posteriores. Lo común para estas fuentes es que posean algunas secuencias de transición, además de otras provenientes de las dos tradiciones de la secuencia temprana e, inclusive, que convivan con secuencias plenamente rimadas o "clásicas" más recientes.Y aunque presentan algunas secuencias antiguas, signo de continuidad, y otras modernas, síntoma de vanguardia, por medio de la secuencia de transición, estas fuentes también articulan, por lo general, una mediadora ruptura con la tradicional barrera establecida entre el Este y el Oeste ${ }^{109}$.

\section{El estilo de la secuencia a partir del siglo XII}

Como venimos diciendo, la secuencia, como una categoría de canción litúrgica medieval, estuvo en una constante mutación, y, en este sentido, uno de los acontecimientos más significativos que se produjeron en el repertorio después del año 1100 fue el hecho de que se regularizase y homogeneizase el

108 Once de las secuencias de transición son conocidas por doquier: Laetabundus exultet, Victimae phascali, Congaudentes exsultemus / vocali, Caeleste organum hodie, Gaudete vos fidelis, Virginae Mariae laudes intonent Christiani, Sacrosanta hodiernae, Sancti merita Benedicti, Stola iocundutatis, Virgines castae y Clara chorus dulce pangat. Se salvó así esa especie de obstáculo -convertido en barrera- en lo que a la recepción de secuencias tempranas entre el Este y Oeste se refiere.

${ }^{109} \mathrm{Al}$ menos existen seis fuentes que contienen entre siete y diez secuencias de transición: Cambrai, Bibl. municipale, ms 78; Cambrai, Bibl. municipale, ms 60; París, Bibl. Nat., lat. 3126; Londres, Br. Libr. Cotton Caligula A XIV 14; Laon, Bibl. municipale, ms 263, y Tortosa, Bibl. Capitular, Cod. 135 (véase P. Peláez Bilbao: Las secuencias del manuscrito..., vol. 1, pp. 176-180). Sin embargo, la mayoría de los manuscritos de los siglos XI, XII e, incluso, XIII que contienen secuencias de transición, todavía dan prioridad a un repertorio temprano y de carácter regionalista para sus secuencias. Algunos pueden contener una o dos secuencias de transición pero, en general, sus repertorios no cambian prácticamente en nada. Un ejemplo de esto es un gradual del siglo XII, Bruselas, Bibl. Royale, II 3823 (Fétis 1172), donde la mayoría de sus secuencias eran ya conocidas en el Oeste, pero que introduce algunos rasgos de modernidad: dos o tres secuencias de transición, junto a una de las primeras secuencias rimadas, Laudes crucis attollamus (véase ejemplo 3), y una de las secuencias "plenas" del estilo del siglo XII, Virgines egregiae / Virgines. Este es el caso claro de un repertorio temprano del siglo XII, que demuestra a la vez continuidad e innovación, con nuevas secuencias del estilo nova cantica, pero que no aporta nuevo repertorio de secuencias de transición. Muchas fuentes que encontramos entre el 1050 y 1150 son como esta del priorato cluniacense de Sauxillanges, en Souvigny (Auvergne): presentan, inclusive, la confrontación en el mismo folio de la versión de ambas tradiciones. 
género, de que se normalizara. Este cambio fue lo suficientemente significativo como para que hoy se pueda hablar de un "segundo estilo"y hasta de "secuencia clásica" en la vida de la secuencia, siendo este un momento de gran esplendor y auge del repertorio. Para la explicación de este apartado, nos hemos apoyado fundamentalmente en las numerosas y referenciales investigaciones realizadas por Fassler al respecto ${ }^{110}$. Así, a imagen de la "neues Lied", Fassler centra sus estudios en la "nueva secuencia", la que nosotros denominamos del segundo estilo; principalmente alrededor de un poeta y compositor paradigmático,Adam de SaintVictor; y en un lugar concreto, la abadía de SaintVictor de París y su entorno. Pero va mucho más allá, dedicando un espacio también a la catedral de Notre Dame y sus influencias en otros centros parisinos y de otras regiones. Busca y analiza su lugar de origen, desarrollo, prosperidad y expansión regional y cronológica.

Inmersa en todo el nuevo interés y revitalización del verso rítmico que se dio a finales del siglo XI, veamos cómo la secuencia comenzó a ser escrita predominantemente en un tipo de versificación latina caracterizada por la regularidad, la rima y el acento, en vez de en los hasta entonces utilizados pareados en prosa o los titubeantes ensayos estilísticos, entre una cosa y la otra, de la transición.

A raíz de esta nueva manera de concebir el género, los poetas del siglo XII desarrollaron algunos modelos de versificación para las secuencias y otros tipos similares de poesía litúrgica, como el versus, el conductus o el himno; modelos que fueron detallada y sistemáticamente descritos en los tratados sobre el arte de la poesía rítmica del momento ${ }^{111}$. Sin duda, como dice Fassler ${ }^{112}$, la más popular forma de versificación de la secuencia poética fue aquella empleada en la más famosa y extendida secuencia del siglo XII, Laudes crucis attolamus (ejemplo 3), para las festividades de la Cruz, es decir, la imitación del septenario trocaico $(8 p+8 p+7 p p)^{113}$.

${ }^{110}$ Margot E. Fassler: "Sequence, late", Dictionary of the Middle Ages, Joseph. R. Strayer (ed.), Nueva York, Scribner, 1982-1985, vol. 11, pp. 166-167; -: Musical Exegesis in the Sequences of Adam and the Canons of St Victor, tesis doctoral, Cornell University, 1983; —: "Who was Adam of Saint Victor? The Evidence of the Sequence Manuscripts", Journal of the American Musicological Society, 37, 1984, pp. 233-269; —: "Accent, Meter, and Rhythm in Medieval Treatises 'De rithmis", Journal of Musicology, 5, 1987, pp. 164-190; —: "The Role of the Parisian Sequence in the Evolution of Notre-Dame Polyphony", Speculum, 62, 1987, pp. 345-374; - : "The Disappearance of the Proper Tropes and the Rise of the Late Sequence: New Evidence from Chartres", Cantus Planus. Papers Read at the Fourth Meeting Pécs, Hungary 3-8, September 1990, László Dobszay (ed.), Budapest, Hungarian Academy of Sciences / Institute for Musicology, 1992, pp. 319-335; —: Gothic Song...; -: The Virgin of Chartres. Making History through Liturgy and the Arts, New Haven, Yale University Press, 2010; -: Music in the Medieval West, Nueva York, W. W. Norton \& Company, 2014, pp. 56-78; - " "Women and Their Sequences. An Overview and a Case Study", Speculum, 94, 3, 2019, pp. 625-673.

${ }^{111}$ Para una discusión sobre el tema y un estudio de estos tratados véase M. E. Fassler: "Accent, Meter...", pp. 164-190.

${ }^{112}$ M. E. Fassler: Gothic Song..., pp. 64-78.

${ }^{113}$ Dag Norberg: An Introduction to the Study of Medieval Latin Versification, Washington, The Catholic University of America Press, 2004, pp. 107-108 
Nuestro ejemplo consiste en poesía estrófica. En ella, cada estrofa se divide en dos mitades pareadas (salvo la primera), con la misma música para cada una de ellas, sugiriéndose de esta manera la estructura típica de las secuencias tempranas aunque, de manera distinta, manteniendo la regularidad del cómputo silábico de principio a fin. Así, la estructura bipartita de cada estrofa está enfatizada no solo por la presentación de las mitades de estrofa con la misma música, sino también gracias a la rima de las cadencias finales de cada mitad de pareado. El empleo frecuente de la aliteración (por ejemplo, "dulce lignum dulci dignum"), de las rimas internas dentro de cada frase pareada ("Dulce melos tangat caelos") y de la asonancia ("melodia-symphonia"), son otros recursos empleados habitualmente por los autores de secuencias a partir del XII y que encontramos constantemente en este caso.

Desde el comienzo las unidades melódicas ${ }^{114}$ parecen desplegarse según el principio de la variación: cada una está interconectada con la inmediatamente anterior y con la inmediatamente posterior. Por tanto, la música de toda la secuencia funciona como una cadena de eventos particulares, cada uno vinculado con el otro a través de diversos recursos de variación. De hecho, la mayor parte de la melodía pareciera haber sido generada de la primera unidad melódica que, por cierto, procede del Alleluia Dulce lignum. A partir de esta "concatenación" de unidades melódicas, la estructura general de la melodía queda conformada como una sucesión de frases pareadas (cada pareado para una estrofa del texto), en la que los finales están puntualizados por fórmulas cadenciales muy similares, que sirven para enfatizar los acentos y las cadencias rítmicas de la poesía, dando por momentos en la pieza una sensación de "estribillo" musical.

A grandes rasgos, pues, puede decirse que Laudes crucis attollamus está organizada musicalmente como una secuencia temprana (pareados con distinta música), pero textualmente como un himno (carácter estrófico). Tiene un estilo y estructura que reflejan las características de ambos géneros, fundiéndolos para hacer algo nuevo, que en ningún caso deja de ser una secuencia; no solo por la forma, sino también por su lugar particular dentro de la misa y por todas las asociaciones alegóricas -no olvidemos su plausible familiaridad con los salmos- construidas en torno a ella a lo largo de los siglos.

Sin embargo, a pesar del parentesco de ciertos principios formales con las secuencias tempranas, Laudes crucis attollamus habla con un acento sustancialmente diferente al empleado comúnmente por estas. Sus temas y sus valores exegéticos han cambiado: el objetivo prioritario ya no es buscar la unión en el canto con las cohortes angélicas, sino comprender y profundizar en todos los significados de

${ }^{114}$ Cada unidad melódica se corresponde plenamente con una célula textual. Así, por ejemplo, en la primera estrofa tenemos "Laudes crucis attolamus" - "nos qui crucis exultamus" - "speciali gloria"; en la segunda, "Dulce melos tangat celos" - "dulce lignum dulci dignum" - "credimus melodia" / "Voce vita non discordet" - "cum vox vitam non remordet" - "dulcis est simphonia"; y así sucesivamente... 
las Escrituras, tomándose estas como la representación del lenguaje de signos de Dios aludido por San Agustín, por ejemplo, en De doctrina christiana ${ }^{115}$. Como dice Hugo de Saint-Victor: Primum fit sermo Dei ad nos, postea sermo noster ad Deum [primero sea la palabra de Dios hacia nosotros, después nuestra palabra a Dios] ${ }^{116}$. Así, en esta secuencia, por ejemplo, están remarcadas la idea de los sacramentos, tal y como estos tienen lugar en la Iglesia, y la relevancia de los sacerdotes, ya sea como celebrantes o en conexión con la Cruz y sus significados, a través de los poderes litúrgicos del ministerio. De hecho, el poeta en realidad es como si tuviese la determinación de escribir un comentario litúrgico versificado, partiendo de imágenes y conceptos del Antiguo Testamento y describiendo la devoción comunitaria a los misterios de la Cruz.

1. Laudes crucis attolamus

nos qui crucis exsultamus

speciali gloria

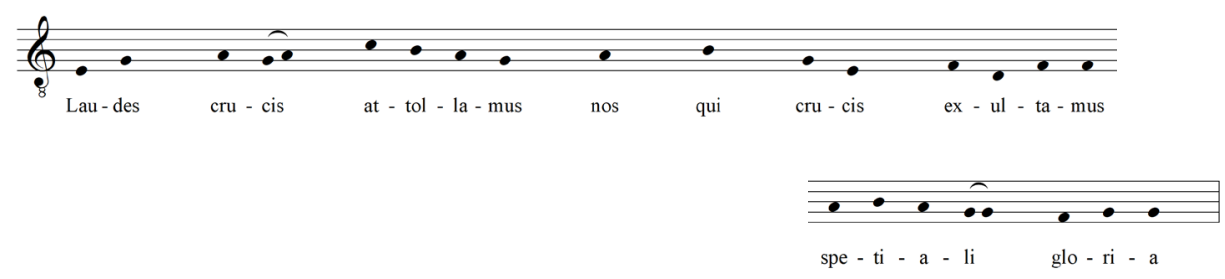

2a. Dulce melos tangat caelos dulce lignum dulci dignum credimus melodia 2b. Voce uita non discordet

cum uox uitam non remordet dulcis est symphonia

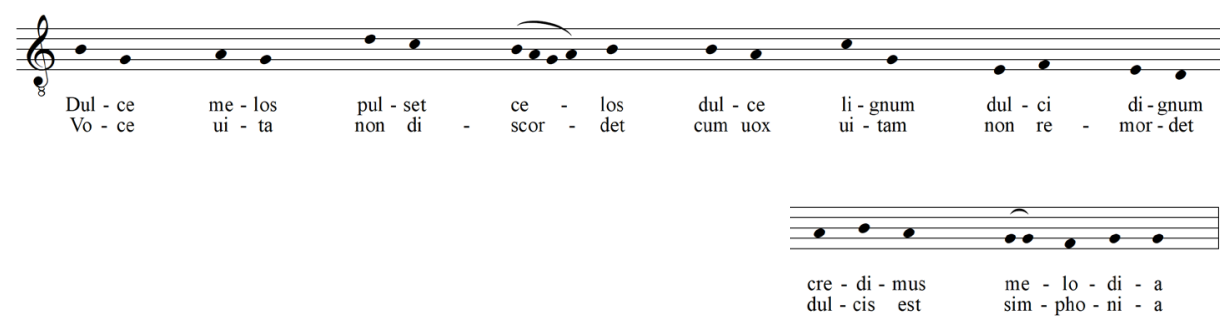

115 Véase un análisis en este sentido en Rainer Berndt: "La pratique exégétique d'André de Saint-Victor: tradition victorine et influence rabbinique", L'Abbaye parisienne de Saint-Victor au Moyen Âge. Communications présentées au XIII Colloque d'Humanisme médiéval de Paris (1986-1988), Jean Longère (ed.), Turnhout, Brepols, 1991, p. 275.

${ }^{116}$ Hugo de Saint-Victor: Didascalion de studio legendi: A Critical Text, Charles Henry Buttimer (ed.), Washington, The Catholic University Press, 1939, p. 74. 
3a. Servi crucis crucem laudent qui per crucem sibi gaudent uitae dari munera 3b. O quam felix quam praeclara fuit haec salutis ara rubens agni sanguine

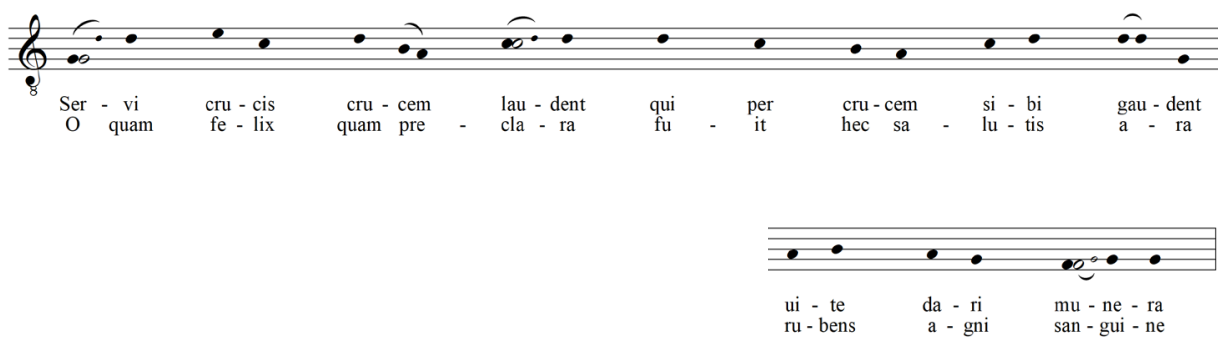

4a. Agni sine macula qui mundauit saecula $\mathrm{ab}$ antiquo crimine 4b. Dicant omnes et dicant singuli aue salus totius saeculi arbor salutifera
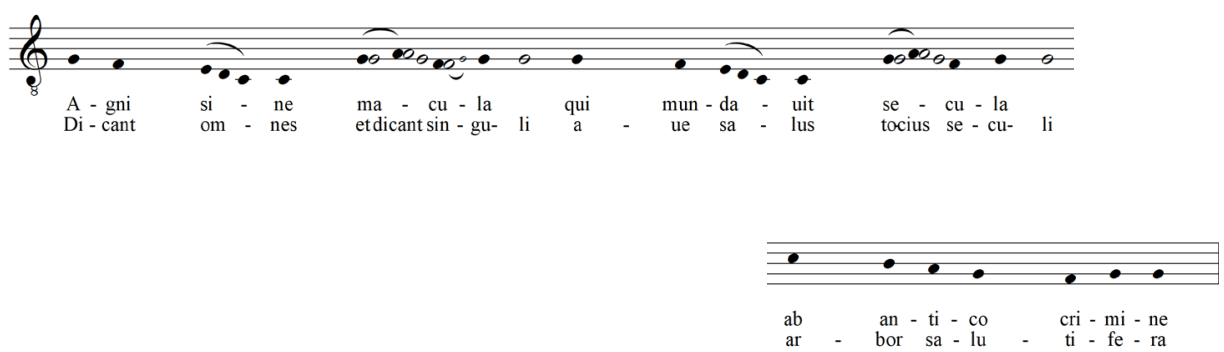

5a. Haec est scala peccatorum perquam Christus rex caelorum ad se traxit omnia 5b. Forma cuius hoc ostendit quae terrarum comprehendit quattuor confinia
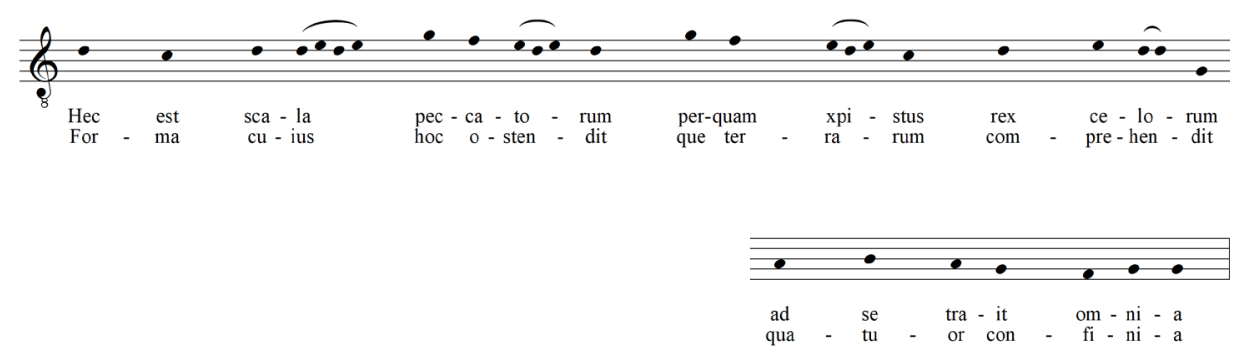
6a. Ligna legens in Sarepta spem salutis est adepta pauper muliercula 6b. Sine lignis fidei nec lechytus olei ualet nec farinula

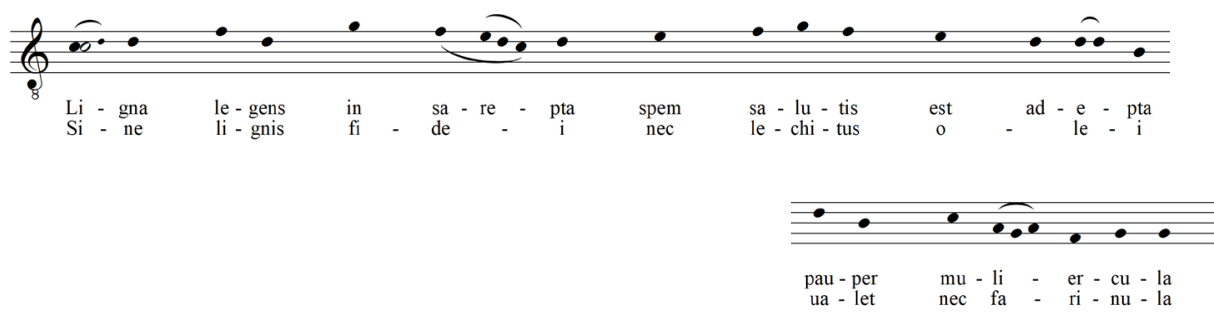

7a. Roma naues uniuersas in profundum uidit mersas una cum Maxentio

7b. Fusi Traces caesi Persae sed et partis dux aduersae uictus ab Heraclio

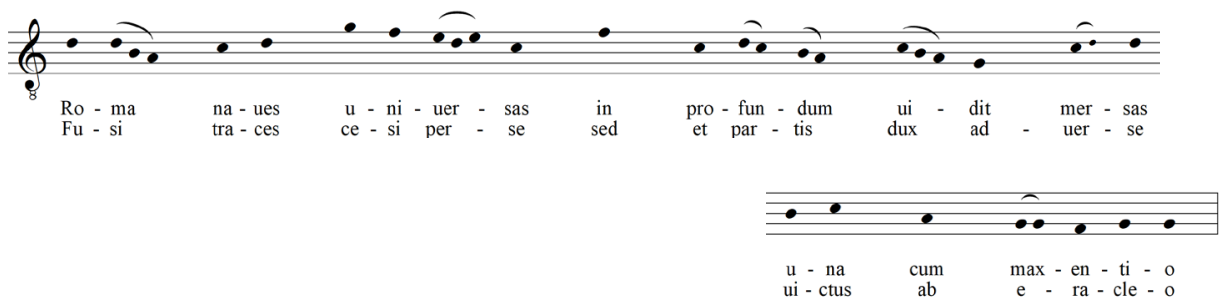

8a. In scripturis sub figuris ista latent sed iam patent crucis beneficia

8b. Reges credunt hostes cedunt sola cruce Christo duce unus fugat milia

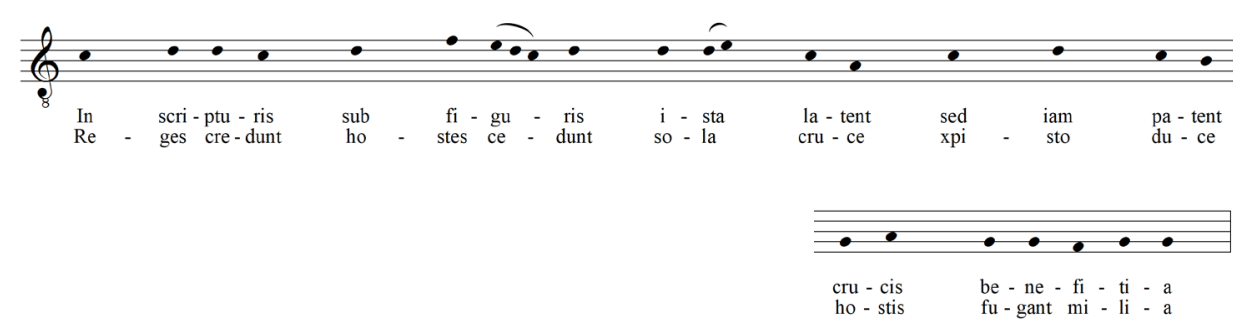


9a. Non sunt noua sacramenta nec recenter est inuenta crucis haec religio 9b. Ista dulces aquas fecit per hanc silex aquas iecit Moysi officio

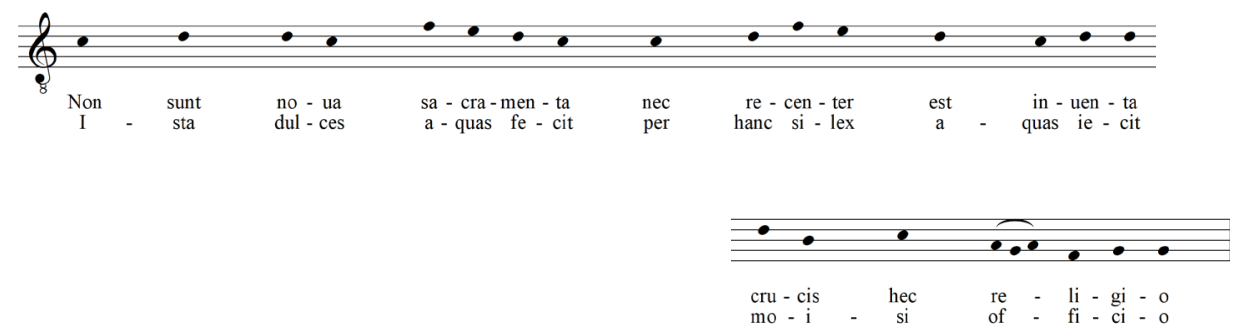

10a. Ista suos fortiores semper facit et uictores morbos sanat et languores reprimit daemonia 10b. Dat captiuis libertatem uitae confert nouitatem ad antiquam dignitatem crux reduxit omnia

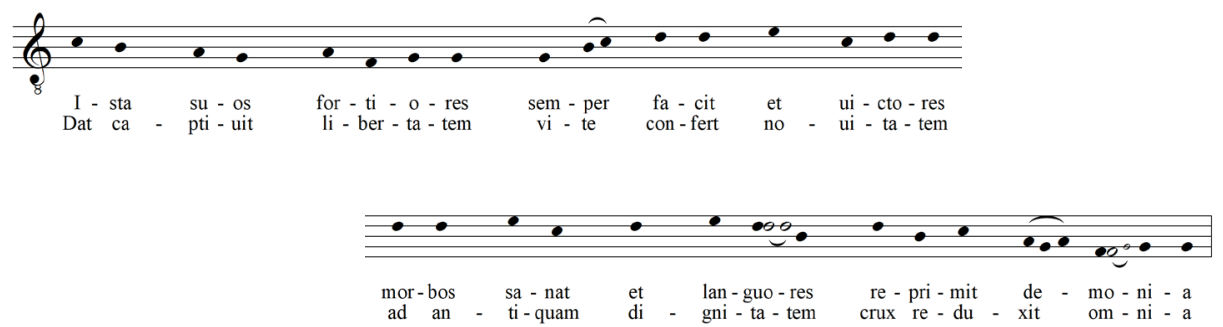

11a. O crux lignum triumphale mundi uera salus uale inter ligna nullum tale fronde flore germine

11b. Medicina christiana salua sanos aegros sana quod non ualet uis humana fit in tuo nomine

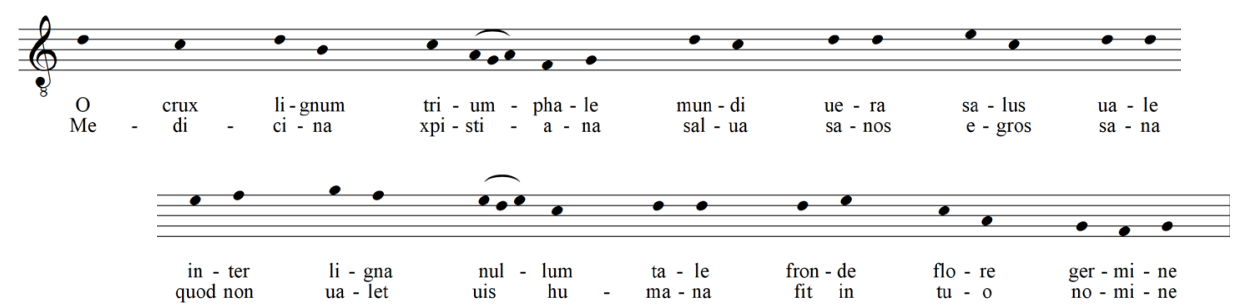


12a. Assistentes crucis laudi consecrator crucis audi atque seruos tuae crucis post hanc uitam uerae lucis transfer ad palatia 12b. Quos tormento uis seruire fac tormenta non sentire sed cum dies erit irae nobis confer et largire sempiterna gaudia

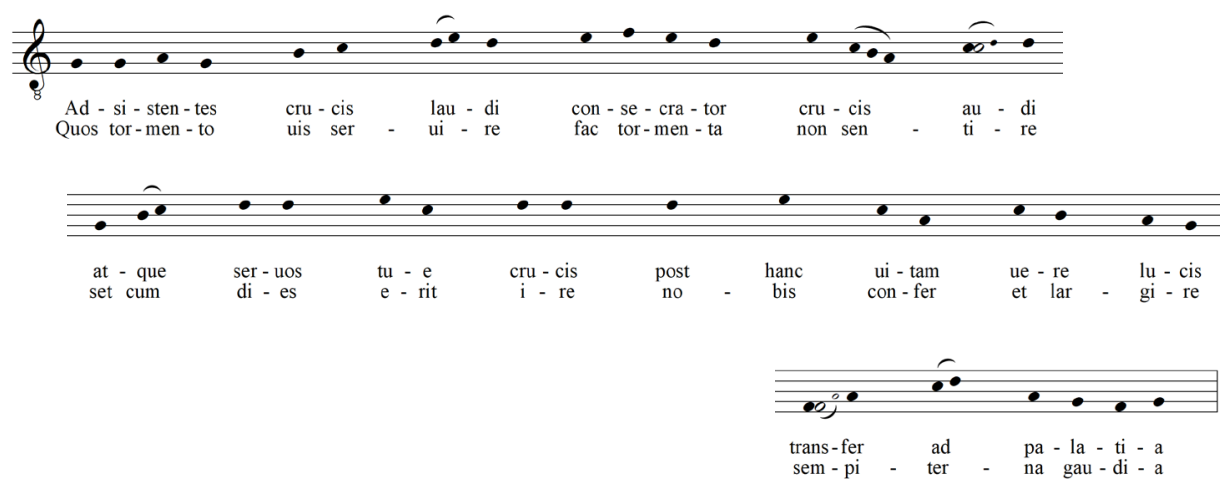

AMEN

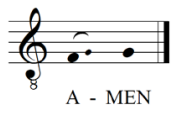

Ejemplo 3. Laudes crucis attolamus. Tortosa, Bibl. Capitular, Cód. 135, ff. 51r-53r (s. XIII med) $)^{117}$

Para resumir, a partir del modelo prototípico de Laudes crucis attollamus, podemos decir que la secuencia de la segunda época se caracteriza por: estar en un tipo de verso equilibrado y simétrico, basado en la regularización de la construcción de la estrofa a partir de una composición determinada por la alternancia de acentos tónicos y átonos y la multiplicidad de rimas. Además, esta regularidad, marcada por el ritmo y la rima, suele articularse a través de la alternancia de versos octosílabos con algunos heptasílabos. Melódicamente, se da un vuelco hacia un silabismo menos estricto, más flexible.Asimismo, la secuencia como género adquiere un carácter "polimelódico", de manera que, a diferencia de lo que sucedía con las secuencias tempranas, se da la circunstancia de que un texto podía tener varias melodías asociadas a él, lo cual no impide que se siguiese empleando de manera copiosa la técnica del contrafactum.

Todos estos cambios de acento en el lenguaje y en la concepción de la secuencia en este "estilo clásico", así como en lo que a su naturaleza a la manera de comentario o reflexión litúrgica se refiere, inmediatamente la arraigan a

${ }^{117}$ La normalización del texto poético y la presentación de la lectura propia del manuscrito sigue, de manera general, los principios editoriales expuestos muy recientemente en A. Tello Ruiz-Pérez, P. Peláez Bilbao: "La prosa Gratulemur et laetemur...", pp. 221-231. Véase también P. Peláez Bilbao: Las secuencias del manuscrito..., vol. 2, pp. 15-27. 
unas fechas concretas, a partir del siglo XII; a un lugar, París, y a unas nuevas corrientes de pensamiento, marcadas por la reforma agustiniana, el florecimiento de Notre-Dame y el incipiente desarrollo escolástico de la universidad.

En efecto, las fuentes que contienen los primeros grandes repertorios de secuencias tardías demuestran que París fue quizá el más importante centro de producción durante el siglo XII ${ }^{118}$.Y precisamente estos repertorios estuvieron enraizados en dos tradiciones distintas de secuencias parisinas: por un lado, la de Notre-Dame y, por otro, la de la abadía agustiniana de Saint-Victor ${ }^{119}$. La más temprana de estas tradiciones fue la de la catedral, esto es, la colección de cantos creados en la primera mitad del siglo XII por Adam Precentor y su escuela. Pero, en algún momento de 1130,Adam dejó la catedral para ingresar en la abadía de Saint-Victor, por lo que, como dice Fassler: "Él es probablemente uno y el mismo famoso poeta llamado Maestro Adán de S.Víctor por Tomás de Cantimpré en el siglo XIII, y mencionado por ambos, Ricardo de S.Victor y Alano de Lile en el siglo XII"120.

El gran repertorio de secuencias creado por Adam y su escuela sirvió como punto de arranque de una segunda escuela, formada por compositores victorinos, a partir de la segunda mitad del siglo XII. En la producción de este segundo gran repertorio parisino, los victorinos desarrollaron un sistema único de simbolismo musical que creció a la luz de los escritos de Hugo de Saint-Victor y sus nociones particulares acerca de los propósitos del arte religioso ${ }^{121}$.

Parejo a este impulso estilístico victorino, no hay que obviarlo, aunque ya presente desde sus primeros pasos como género, la secuencia, como encarnación de los más arraigados impulsos de libertad creativa, fue susceptible de ser interpretada polifónicamente. Desde los ejemplos de organum en Musica y Scolica Enchiriadis, hasta la gran polifonía de Notre-Dame de París y mucho más allá, pasando por los troparios-prosarios de Winchester o de Saint-Martial de Limoges, encontramos secuencias cantadas a varias voces, amplificándose así, por momentos, sus posibilidades exegéticas en sentido vertical ${ }^{122}$.

118 Según Fassler, destacan los siguientes prosarios: París, Bibliothéque Nationale, lat. 14506 (St. Victor, ca. 1200); París, Bibliothéque Nationale, lat. 14452 (victorino, ca. 1200-1235); París, Bibliothéque Nationale, lat. 14819 (1140-1220); París, Bibliothéque Nationale, lat. 13252 (St. Magloire, XI ex); París, Bibliothéque Nationale, lat. 1112 (Notre-Dame, ca. 1200); París, Ste. Genevieve 1259 (Ste. Genevieve, s. XIII); París, Bibliothéque Mazarine 526 (St. Denis, 1234-1236). Véase M. E. Fassler: Gothic Song..., pp. 139, 147.

119 Heinrich Husmann: "Notre-Dame und Saint-Victor. Repertoire-Studien zur Geschichte der gereimten Prosen (Schluß)”, Acta Musicologica, 36, 1964, pp. 98-123.

${ }^{120}$ M. E. Fassler: "Sequence, late", p. 167: "He is probably one and the same with the famous poet called Magister Adam of St. Victor by Thomas of Cantimpré in the thirteenth century, and mentioned by both Richard of St. Victor and Alan of Lille in twelfth century".

${ }^{121}$ Edgar de Bruyne: "La estética de los victorinos", Estudios de estética medieval, Madrid, Gredos, 1959, vol. 2, pp. 215-265; M. E. Fassler: "Who was Adam of Saint Victor?...”, pp. 233-269.

${ }^{122}$ Brian R. Gillingham: A History of the Polyphonic Sequence in the Middle Ages, tesis doctoral, University of Washington, 1976. 


\section{Breves consideraciones finales}

¿Qué hace a una secuencia ser una secuencia? Implícita desde el principio, dos han sido los enfoques por medio de los cuales hemos pretendido dar respuesta a esta pregunta para adentrarnos en la clarificación de la secuencia medieval como concepto: una generalización definitoria de lo que hemos denominado "forma lógica", estática, articulada sobre todo a raíz de su relación nativa con el Alleluia y el Evangelio de la misa franco-romana; y un repaso sucinto por el entramado de sus estilos, en tanto la "forma dinámica" que también es.

El primer enfoque ha aspirado a adquirir un modelo razonable de identificación, abstraíble de forma estable más allá de las condiciones y artificios, morfologías o circunstancias, con las que cada obra del género secuencia pueda presentársenos. El segundo, tomando ese modelo como elemento común parangonable, ha pretendido desentrañar la compleja madeja en la que el género fue enredándose -entiéndasenos, para nuestra manera moderna de ver algo tan lejano como un producto medieval- a lo largo y ancho de su historia. Ambos enfoques son complementarios, ambos han sido necesarios.

De la conjunción de dichos enfoques, emana de forma sintética una definición para la secuencia que, en todo caso, como género independiente, la excluye de ser una prolongación o división del tropo, como se ha visto en ocasiones por parte de la crítica. Así, una secuencia es:

En la misa franco-romana de la Edad Media latina, una categoría de canto que, entre el Alleluia y el Evangelio, supone un punto exegético de armonización, coordinación y conexión entre el Antiguo y el Nuevo Testamento para las solemnidades más importantes del año litúrgico. Con una dimensión que va desde la pura melodía hasta la melodía textuada total o parcialmente, su forma y rasgos estilísticos, muy variados en su historia y tradiciones, dependen en primer término de la condición de ser un canto de nueva composición y, por tanto, no universal y preceptivo, aunque prevalece a lo largo del tiempo una estructura característica a base de pareados autónomos melódica y textualmente.

Mucho más allá de esta definición, la miríada de posibilidades de estudio que ofrece el género, ya desde su misma complejidad estilística intrínseca, posee un carácter abarcador. Para empezar, entre otras cuantiosas líneas de trabajo, queda a la espera urgente la elaboración de un catálogo completo y exhaustivo de composiciones y fuentes; también el estudio comparado y sistemático de sus tradiciones, que arroje resultados equiparables a los de otros repertorios de canto medieval; al igual que el análisis pormenorizado de las diferentes tipologías puede, sin duda, no solo ahondar en las relaciones texto y música, sino, a través precisamente de ellas, arrojar nuevas perspectivas a las investigaciones en la exégisis, la teología y liturgia de la Edad Media, etc. 
La cuestión queda abierta, no puede ser de otro modo.Ahora lo que se impone es exhortar al estudio de las cualidades de transmisión cultural que la secuencia atesora. En un mundo como el nuestro, repleto de conexiones, inculturaciones, recepciones, relaciones..., la secuencia, un mero canto medieval -0 , mejor, la canción litúrgica en su conjunto-, como por arte de magia, se convierte en un escenario privilegiado de ensayo, si no de comprensión razonable, de que cada realidad ha de ser considerada en la totalidad de los factores que la constituyen.

\section{Bibliografia}

Andrieu, Michel (ed.): Les Ordines Romani du Haut Moyen Âge. Les Textes (Ordines I-XIII), Lovaina, Spicilegium Sacrum Lovaniense, vol. 2, 1948.

Anglès, Higini: La música a Catalunya fins al segle XIII, Barcelona, Biblioteca de Catalunya, 1935.

Artt, Wulf: "Sequence and Neues Lied”, La Sequenza Medievale. Atti Del Convegno Internazionale, Milano, 7-8 aprile 1984, Agostino Ziino (ed.), Lucca, Libreria Musicale Italiana, 1992, pp. 3-18.

BABв, Warren: Hucbald, Guido and John on Music. Three Medieval Treatises, New Haven, Yale University Press, 1978.

Baroffio, Giacomo (ed.): Iter Liturgicum Italicum, Padua, CLEUP, 1999.

BARret, Sam: "Latin Song at the Abbey of Sankt Gallen from c. 800 to the Liber Ymnorum", Early Music History, 38, 2019, pp. 1-50.

BERNDT, Rainer: "La pratique exégétique d'André de Saint-Victor: tradition victorine et influence rabbinique", L'Abbaye parisienne de Saint-Victor au Moyen Âge. Communications présentées au XIII Colloque d'Humanisme médiéval de Paris (1986-1988), Jean Longère (ed.), Turnhout, Brepols, 1991, pp. 271-290.

BJörkvall, Gunilla; Haug, Andreas: "Sequence and Versus: On the History of Rhythmical Poetry in the Eleventh Century", Latin Culture in the Eleventh Century. Proceedings of the Third International Conference on Medieval Latin Studies, Cambridge (1998), Michael W. Herren, Christopher J. McDonough, Ross G. Arthur (eds.), Turnhout, Brepols, 2002, vol. 1, pp. 57-82.

Bona, Joanne: Rerum liturgicarum libri duo, Roma, Typis Nicolai Angelii Tinassii, 1671.

Bower, Calvin M.: "An Alleluia for Mater", Essays on the Music of J. S. Bach and Other Divers Subjects. A Tribute to Gerhard Herz, Robert L. Weaver (ed.), Nueva York, Pendragon Press, 1982, pp. 98-116.

—: "Alleluia, Confitemini Domino, Quoniam Bonus - An Alleluia, Versus, Sequentia, and Five Prosae Recorded in Aquitanian Sources", Music in the Theater, Church and Villa: Essays in Honor of Robert LamarWeaver and Norma Wright Weaver, Susan Parisi (ed.), Warren, Míchigan, Harmonie Park Press, 2000, pp. 3-30.

—: "From Alleluia to Sequence. Some Definitions of Relations", Western Plainchant in the First Millennium. Studies in the Medieval Liturgy and its Music, Sean Gallagher (ed.), Burlington, Ashgate, 2003, pp. 351-398. 
—: The LiberYmnorum of Notker Balbulus, 2 vols. Londres, Henry Bradshaw Society, 2016.

Brunner, Lance W.: The Sequences of Verona, Biblioteca Capitolare XVII and the Italian Sequence Tradition, tesis doctoral, University of North Carolina at Chapell Hill, 1977.

—: "Catalogo delle sequence in manoscritti di origine italiana anteriori al 1200", Rivista Italiana de Musicologia, 20, 1985, pp. 191-276.

Bruyne, Edgar de: "La estética de los victorinos", Estudios de estética medieval, Madrid, Gredos, 1959, vol. 2, pp. 215-265.

Cattin, Giulio: Historia de la Música 2. El Medioevo. Parte I, Madrid,Turner Música, 1987.

Crocker, Richard L.: The Repertory of Proses at Saint Martial de Limoges (Tenth and Eleventh Centuries), tesis doctoral,Yale University, 1957.

-: "The Repertory of Proses at Saint Martial de Limoges in the Tenth Century", Journal of the American Musicological Society, 11,1958, pp. 149-164.

—: "Some Ninth-Century Sequences", Journal of the American Musicological Society, 20, 1967, pp. 367-402.

—: The Early Medieval Sequence, Berkeley, University of California Press, 1977.

—: "Sequence", The New Grove Dictionary of Music and Musicians, Stanley Sadie (ed.), Londres, Macmillan, 1980, vol. 17, pp. 141- 153.

-: "Medieval Chant", New Oxford History of Music. 2. The Early Middle Ages to 1300, Richard L. Crocker, David Hiley (eds.), Oxford, Oxford University Press, 1990, pp. 225-309.

Curtius, Ernst Robert: Literatura europea y Edad Media latina, 2 vols., México, Fondo de Cultura Económica, 1955.

Deusen, Nancy van: “The Use and Significance of the Sequence”, Musica Disciplina, 40, 1986, p. $5-47$.

Dreves, Guido Maria; Blume, Clemens; Bannister, Henry Marriott: [AH] Analecta Hymnica Medii Aevi, 55 vols., Leipzig, O. R. Reisland, 1886-1922.

Dronke, Peter:"The Beginnings of the Sequence", Beiträge zur Geschichte der deutschen Sprache und Literatur, 87, 1965, pp. 43-73.

DüMmler, Ernst (ed.): Epistolae Karolini aevi. 2. Epistolae 4, Munich, Monumenta Germaniae Historica, 1978.

ELFVING, Lars: Étude lexicographique sur les séquences limousines, Estocolmo, Almqvist \& Wiksell, 1962.

Evans, Paul: “Sequence”, The New Harvard Dictionary of Music, Don M. Randel (ed.), Cambridge, Massachusetts, Belknap Press of Harvard University Press, 1986, pp. 739-740.

FalCOner, Keith A.: Some Early Tropes to the Gloria, tesis doctoral, Princeton University, 1989.

Fassler, Margot E.: "Sequence, late", Dictionary of the Middle Ages, Joseph. R. Strayer (ed.), Nueva York, Scribner, 1982-1985, vol. 11, pp. 166-167.

-: Musical Exegesis in the Sequences of Adam and the Canons of St Victor, tesis doctoral, Cornell University, 1983.

- "Who was Adam of SaintVictor? The Evidence of the Sequence Manuscripts", Journal of the American Musicological Society, 37, 1984, pp. 233-269.

-: "Accent, Meter, and Rhythm in Medieval Treatises 'De rithmis", Journal of Musicology, 5, 1987, pp. 164-190. 
- "The Role of the Parisian Sequence in the Evolution of Notre-Dame Polyphony", Speculum, 62, 1987, pp. 345-374.

- "The Disappearance of the Proper Tropes and the Rise of the Late Sequence: New Evidence from Chartres", Cantus Planus. Papers Read at the Fourth Meeting Pécs, Hungary 3-8, September 1990, László Dobszay (ed.), Budapest, Hungarian Academy of Sciences / Institute for Musicology, 1992, pp. 319-335.

-: Gothic Song. Victorine Sequences and Augustinian Reform in Twelfth-Century Paris, Cambridge, Cambridge University Press, 1993.

—: Music in the Medieval West, Nueva York,W.W. Norton \& Company, 2014.

-: The Virgin of Chartres. Making History through Liturgy and the Arts, New Haven, Yale University Press, 2010.

—: "Women and Their Sequences. An Overview and a Case Study", Speculum, 94, 3, 2019, pp. 625-673.

Gillingham, Brian R.: A History of the Polyphonic Sequence in the Middle Ages, tesis doctoral, University of Washington, 1976.

Graduale Triplex, edición crítica a cargo de los monjes de Solesmes, Solesmes, Abbaye de Saint Pierre / París, Desclée, 1979.

Grout, Donald. J.; Palisca, Claude V.: Historia de la Música Occidental, 2 vols., Madrid, Alianza Música, 1997.

Gutiérrez, Carmen Julia: "Secuencia", Diccionario de la música española e hispanoamericana, Emilio Casares Rodicio (dir.), Madrid, SGAE, 1999-2002, vol. 9, pp. 879-882.

Hammerstein, Reinhold: Die Musik der Engel. Untersuchungen zur Musikanschauung des Mittelalters, Berna, Francke, 1962.

Handschin, Jacques: “Trope, Sequence and Conductus", New Oxford History of Music. 2. Early Medieval Music up to 1300, Anselm Hughes (ed.), Londres, Oxford University Press, 1954, 128-174.

Hanssens, Jean-Michel (ed.): Amalarii episcopi Opera liturgica omnia, Roma, Biblioteca Apostolica Vaticana, vols. 2-3, 1948-1950.

Hartmann, Wilfried (ed.): Concilia Aevi Karolini, Hanover, Hahn, vol. 3, 1984.

Haug, Andreas: Gesungene und schriftlich dargestellte Sequenz. Beobachtungen zum Schriftbild der ältesten ostfränkischen Sequenzenhandschriften, Neuhausen / Stuttgart, Hänssler-Verlag, 1987.

- : "Ein neues Textdokument zur Entstehungsgeschchte der Sequenz", Festschrift Ulriche Siegele zum 60. Geburtstag, Rudolf Faber (ed.), Kassel, BärenreiterVerlag, 1991, pp. 3-19.

—: "Neue Ansätze im 9. Jahrhundert", Die Musik des Mittelalters, Hartmut Möller, Rudolf Stephan (eds.), Laaber, Laaber-Verlag, 1991, pp. 94-128.

—: "Melisma", Die Musik in Geschichte und Gegenwart 2, Ludwig Finscher (ed.), Kassel, Bärenreiter-Verlag, 1997, vol. 6, pp. 19-29.

- "Re-Reading Notker's Preface", Quomodo cantabimus canticum? Studies in Honor of Edward H. Roesner, David Butler Cannata, Gabriela Ilnitchi Currie, Rena Charnin Mueller, John Louis Nádas (eds.), Middleton, Wisconsin, American Institute of Musicology, 2008, pp. 65-80.

Hesbert, René-Jean: Antiphonale Missarum Sextuplex, Bruselas,Vromant, 1935. 
Hiley, David: “Cluny, Sequences and Tropes”, La Tradizione dei Tropi Liturgici, Claudio Leonardi, Enrico Menestrò (eds.), Spoleto, Centro italiano di studi sull'alto medioevo, 1990, pp. 125138.

—: "The Sequentiary of Chartres Bibliothèque Municipale, Ms. 47”, La Sequenza Medievale. Atti del Convegno Internazionale, Milano, 7-8 aprile 1984, Agostino Ziino (ed.), Lucca, Libreria Musicale Italiana, 1992, pp. 105-117.

—: "The Sequence Melodies Sung at Cluny and Elsewhere", De musica et cantu. Studien zur Geschichte der Kirchenmusik und der Oper: Helmut Hucke zum 60. Geburtstag, Peter Cahn, Ann-Katrin Heimer (eds.), Hildesheim, Olms, 1993, pp. 131-155.

—: Western Plainchant. A Handbook, Oxford, Oxford University Press, 1993.

-: "The Repertory of Sequences at Winchester", Essays on Medieval Music in Honor of David G. Hughes, Graeme M. Boone (ed.), Cambridge, Harvard University Press, 1995, pp. 153193.

Hoppin, Richard H.: La música en la Edad Media, Madrid, Ediciones Akal, 2000.

Hughes, Andrew (ed.): Anglo-French Sequelae. Edited from the Papers of the Late Dr. Henry Marriott Bannister, Burnham, The Plainsong \& Medieval Music Society, 1934.

Huglo, Michel:"La division de la tradition monodique en deux groupes 'est' et 'ouest", Revue de Musicologie, 85, 1999, pp. 5-28.

Husmann, Heinrich: "Sequenz und Prosa", Annales Musicologiques, 2, 1954, pp. 61-91.

—: "Das Alleluia Multifarie und die vorgregorianische Stufe des Sequenzgesanges", Festschrift Max Schneider zum achtzigsten Geburtstage, WaltherVetter (ed.), Leipzig, DeutscherVerlag für Musik, 1955, pp. 17-23.

—: "Alleluia,Vers und Sequenz", Annales Musicologiques, 4, 1956, pp. 19-53.

- "Notre-Dame und Saint-Victor. Repertoire-Studien zur Geschichte der gereimten Prosen (Schluß)", Acta Musicologica, 36, 1964, pp. 98-123.

Jacobsson, Ritva;Treitler, Leo: "Tropes and the Concept of Genre", Pax et Sapientia: Studies in Text and Music of Liturgical Tropes and Sequences in Memory of Gordon Anderson, Ritva Jacobsson (ed.), Estocolmo, Almqvist \& Wiksell, 1986, pp. 59-89.

Jonsson, Ritva, et al.: [CT] Corpus Troporum, 12 vols., Estocolmo, Almqvist \& Wiksell, 1975.

KARCHER, Guillermo Javier: Las antiguas secuencias lemosinas de los tiempos fuertes del año litúrgico. Valoración teológico-litúrgica del Prosario de Analecta Hymnica VII, tesis doctoral, Pontificio Instituto Littúrgico de Roma, 1998.

KoHrs, Klaus Heinrich: Die aparallelen Sequenzen. Repertoire, liturgische Ordnung, musikalischer Stil, Múnich / Salzburgo, Emil Katzbichler, 1978.

Kruckenberg, Lori: The Sequence from 1050-1150: Study of a Genre in Change, tesis doctoral, University of Iowa, 1997.

- "Neumatizing the Sequence. Special Performances of Sequences in the Central Middle Ages", Journal of the American Musicological Society, 59, 2, 2006, pp. 243-317.

—: "The Absence of Transmission. Symptoms of a Musical-Cultural Reception Barrier between the West- and East Frankish Regions", Musik und kulturelle Identität: Bericht über den XIII. Internationaler Kongress der Gesellschaft für Musikforschung in Weimar 2004, Detlef Altenburg, Rainer Bayreuther (eds.), Kassel, Bärenreiter, 2012, vol. 2, pp. 466-76. 
—: "Sequence", The Cambridge History of Medieval Music, Mark Everist, Thomas Forrest Kelly (eds.), Cambridge, Cambridge University Press, 2018, pp. 300-358.

Langer, Susanne K.: Problems of Art. Ten Philosophical Lectures, Londres, Routledge \& Kegan Paul, 1957.

Lubac, Henri de: Exégèse médiévale. Les quatre sens de l'Écriture, París, Aubier, vol. 1, 1959.

Martín Pérez, Balbino (ed.): Obras de San Agustín. Enarraciones sobre los Salmos [Bilingüe], Madrid, Biblioteca de Autores Cristianos, vols. 19-22, 1964-1967.

McKinnon, James: "The Patristic Jubilus and the Alleluia of the Mass", Cantus Planus. Papers read at the Third Meeting of the International Musicological Society Study Group, Tihany, Hungary, 19-24 September 1988, László Dobszay, Péter Halász, János Mezei, Gábor Prószéky (eds.), Budapest, Hungarian Academy of Sciences Institute for Musicology, 1990, pp. 61-70.

-: The Advent Project. The Later-Seventh-Century Creation of the Roman Mass Proper, Berkeley, University of California Press, 2000.

MeYER, Wilhem: Gesammelte Abhandlungen zur mittellateinischen Rythmik, 2 vols., Berlín, Weidmann, 1905.

Norberg, Dag: An Introduction to the Study of Medieval Latin Versification, Washington, The Catholic University of America Press, 2004.

Norden, Eduard: Die antike Kunstprosa vom VI Jahrhundert v. Chr. bis in die Zeit der Renaissance, Leipzig, Teubner, 1898.

Odelman, Eva: "Comment a-t-on appelé les tropes? Observations sur les rubriques des tropes des Xe et XI" siècles”, Cahiers de Civilisation Médiévale, 18, 1975, pp. 15-36.

Peláez Bilbao, Patricia: Las secuencias del manuscrito Tortosa, Archivo Capitular, Cód. 135. Estudio y edición crítica, 2 vols., tesis doctoral, Universidad Complutense de Madrid, 2020.

Polheim, Karl: Die lateinische Reimprosa, Berlín, Weidmann, 1925.

Raby, Frederic James Edward: A History of Christian-Latin Poetry from the Beginnings to the Close of the Middle Ages, Oxford at Clarendon, Oxford University Press, 1953.

Rankin, Susan: “The Earliest Sources of Notker's Sequences in St Gallen, Vadiana 317 and Paris, Bibliothèque Nationale lat. 10587”, Early Music History, 10, 1991, pp. 201-233.

Saint-Victor, Hugo de: Didascalion de studio legendi: A Critical Text, Charles Henry Buttimer (ed.), Washington, The Catholic University Press, 1939.

SCHLAger, Karlheinz: "Beobachtungen zur frühen Sequenz in ost- und westfränkischer Überlieferung”, Gordon Athol Anderson (1929-1981). In memoriam, Luther Dittmer (ed.), Henryville, The American Institute of Musicology, 1984, vol. 2, pp. 531-543.

Silagi, Gabriel: "Vorwort", Liturgische Tropen. Referate zweier Colloquien des Corpus troporum in München (1983) und Canterbury (1984), Munich, Arbeo-Gesellschaft, 1985.

SMITS van WAesBerghe, Joseph: "Einleitung zu einer Kausalitätserklärung der Evolution der Kirchenmusik im Mittelalter (von etwa 800 bis 1400)", Archiv für Musikwissenschaft, 26, 1969, pp. 249-275.

SPANKE, Hans: Beziehungen zwischen romanischer und mittelalterlicher Lyrik, mit besonderer. Berücksichtigung der Metrik und Musik, Berlín, Weidmann, 1936.

SтÄвLEIN, Bruno: “Zur Frügeschichte der Sequenz”, Archiv für Musikwissenschaft, 18, 1961, pp. 1-33. 
-: "Sequenz", Die Musik in Geschichte und Gegenwart, Friedrich Blume (ed.), Kassel, Bärenreiter-Verlag, 1965, vol. 12, col. 522-549.

Steinen, Wolfram von den: "Die Anfange der Sequenzendichtung", Zeitschrift fir Schweizerische Kirchengeschichte, 40-41, 1946-1947, pp. 190-212.

—: Notker der Dichter und seine geistige Welt, 2 vols., Berna, Francke Verlag, 1948.

—: Notkeri Poetae. Liber ymnorum [Notkers des Dichters. Hymnenbuch], Berna / Munich, Francke Verlag, 1960.

Stevens, John: Words and Music in the Middle Ages. Song, Narrative, Dance and Drama, 1050-1350, Cambridge, Cambridge University Press, 1986.

STRECKER, Karl: "Mittellateinische Dichtung in Deutschland", Reallexikon der deutschen Literaturgeschichte, vol. 2, Paul Merker, Wolfgang Stammler (eds.), Berlín, De Gruyter, 1926-1928.

Teeuwen, Mariken: Harmony and the Music of the Spheres. The "Ars Musica" in Ninth-Century Commentaries on Martianus Capella, Leiden, Brill, 2002.

Tello Ruiz-Pérez, Arturo: “Tropo”, Diccionario de la música española e hispanoamericana, Emilio Casares Rodicio (dir.), Madrid, SGAE, 1999-2002, vol. 10, pp. 478-484.

—: "El significado de tropo desde la concepción de género en el mundo medieval", Revista de Musicología, 29, 1, 2006, pp. 45-58.

—: "Rethinking Partially-texted Sequence. Ecce puerpera genuit, between Italy and Catalonia", comunicación no publicada en el Seventeenth meeting of the IMS Study Group "Cantus Planus" (Venecia, 28 de julio al 1 de agosto de 2014).

-: "Tras el rastro de tropos y prosas en el Codex Calixtinus. Una cuestión de método", Quodlibet, 75, 1, 2021, pp. 131-168.

-; Peláez Bilbao, Patricia: “La prosa Gratulemur et laetemur. Una edición crítica”, Quodlibet, 75, 1, 2021, pp. 221-271.

Treitler, Leo: The Aquitanian Repertories of Sacred Monody in the Eleventh and Twelfth Centuries, 3 vols., tesis doctoral, Princeton University, 1967.

Wagner, Peter: Einführung in die gregorianischen Melodien, ein Handbuch der Choralwissenschaft. 1. Ursprung und Entwicklung der liturgischen Gesangsformen bis zum Ausgange des Mittelalters, Leipzig, Breitkopf \& Härtel, 1911.

Weber, Edith: Le Concile de Trente et la Musique. De la Réforme à la Contre-Réforme, París, Librairie Honoré Champion, 1982.

Recibido: 23-7-2021

Aceptado: 16-8-2021 